\title{
Russian Federation: 2010 Article IV Consultation-Staff Report; and Public Information Notice on the Executive Board Discussion
}

Under Article IV of the IMF's Articles of Agreement, the IMF holds bilateral discussions with members, usually every year. In the context of the 2010 Article IV consultation with Russian Federation, the following documents have been released and are included in this package:

- $\quad$ The staff report for the 2010 Article IV consultation, prepared by a staff team of the IMF, following discussions that ended on June 15, 2010, with the officials of Russian Federation on economic developments and policies. Based on information available at the time of these discussions, the staff report was completed on July 09, 2010. The views expressed in the staff report are those of the staff team and do not necessarily reflect the views of the Executive Board of the IMF.

- $\quad$ A Public Information Notice (PIN) summarizing the views of the Executive Board as expressed during its July 23, 2010 discussion of the staff report that concluded the Article IV consultation.

The policy of publication of staff reports and other documents allows for the deletion of market-sensitive information.

\author{
Copies of this report are available to the public from \\ International Monetary Fund • Publication Services \\ $70019^{\text {th }}$ Street, N.W. • Washington, D.C. 20431 \\ Telephone: (202) 623-7430 • Telefax: (202) 623-7201 \\ E-mail: publications@imf.org Internet: http://www.imf.org
}

\section{International Monetary Fund Washington, D.C.}




\title{
INTERNATIONAL MONETARY FUND
}

\author{
RUSSIAN FEDERATION
}

\section{Staff Report for the 2010 Article IV Consultation}

\author{
Prepared by Staff Representatives for the 2010 Article IV Consultation \\ with the Russian Federation
}

Approved by Poul M. Thomsen and Aasim Husain

July 9,2010

\section{Executive Summary}

- Discussions for the 2010 Article IV consultation were held in Moscow during June 2-15. The mission comprised Mr. Thomsen (head), Mr. Kähkönen, Ms. Kozack, Messrs. Hofman and Tiffin, Ms. Zakharova (all EUR), Mr. Tuya (MCM, external expert), and Mr. Brekk (senior resident representative). Mr. Mozhin, Executive Director, also participated in the discussions. The mission met with Deputy Prime Minister and Minister of Finance Kudrin, Central Bank of Russia (CBR) Governor Ignatiev, other senior officials, and representatives of financial institutions, corporations, and think tanks.

- Summary. The Russian economy has improved after a deep recession, but the recovery is fragile. Inflation has come down rapidly in the context of a large output gap, and should remain in check in the near term. The banking system is still under strain and credit is expected to recover only gradually. With Russia likely to emerge from the crisis with lower potential growth, the key policy challenge facing the authorities will be to withdraw the large fiscal stimulus as cyclical conditions normalize to avoid a renewed bout of rapid real appreciation and high inflation. Against this background, staff made the following recommendations:

$>$ On the response to the recession, the authorities acted forcefully, taking full advantage of the buffers afforded by the pre-crisis policy of taxing and saving much of the oil revenue and the attendant large reserves. In this regard, the stabilization fund mechanism has served Russia very well and should be preserved.

$>$ On fiscal policy, the expansion of some 9 percent of GDP has almost entirely taken the form of permanent measures, suggesting that fiscal consolidation will require reinvigorating longstalled public-sector reforms, including in the areas of pensions, health care, and social protection. Staff believes that consolidation should begin in 2010 and gather pace in 2011-12.

$>$ On monetary policy, the focus should be on inflation control in the context of a flexible exchange rate. The recent greater exchange rate flexibility is welcome, but political resolve in this regard remains to be tested in an environment involving a starker tradeoff between inflation and nominal ruble appreciation.

$>$ On financial sector policies, improved provisioning standards are needed to reduce risks to bank balance sheets. In addition, the CBR's authority to conduct consolidated supervisionincluding over connected lending — should be enhanced.

$>$ On structural reforms, the overarching challenge is to improve the investment climate.

- Exchange rate regime. Russia's exchange rate is classified as "other managed arrangement" effective November 1, 2008. The Russian Federation accepted the obligations of Article VIII, Sections 2, 3, and 4 of the IMF Articles of Agreement with effect from June 1, 1996. The exchange system is free of restrictions on payments and transfers for current international transactions.

- It is proposed that the next Article IV consultation be held on the standard 12-month cycle. 


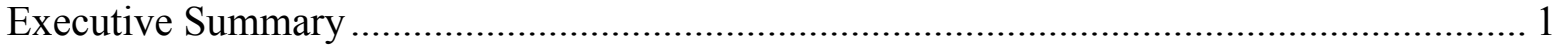

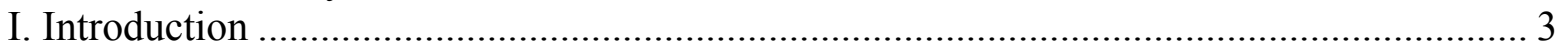

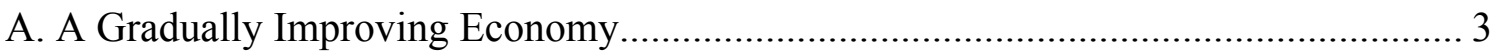

B. Policy Response to the Recession ................................................................... 8

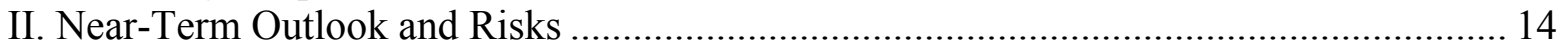

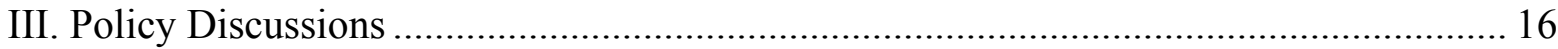

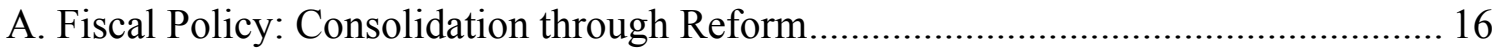

B. Monetary Policy: Focusing on Inflation.............................................................. 18

C. Restoring the Health of the Banking System ..................................................... 20

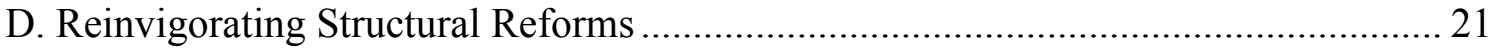

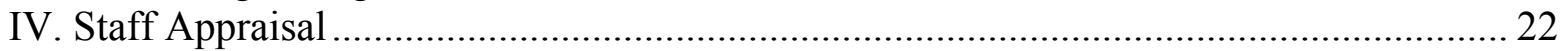

Figures

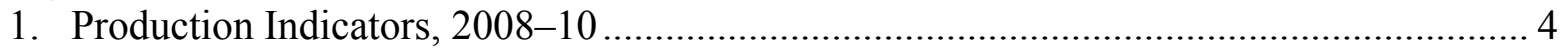

2. Financial Market Indicators, 2007-10 ..................................................................... 7

3. Selected Fiscal Indicators, 2008-10 .................................................................. 9

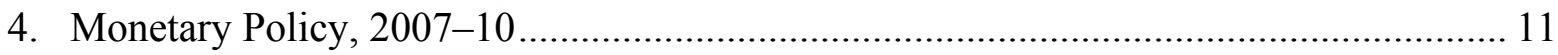

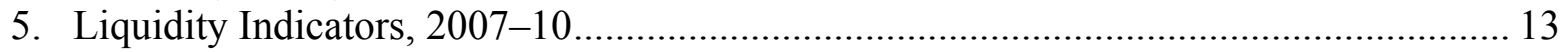

Boxes

1. Regional Spillovers from the Economic Slowdown in Russia .................................. 15

Tables

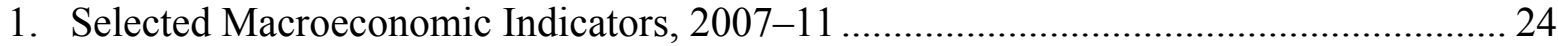

2. Balance of Payments, 2007-11 …............................................................................ 25

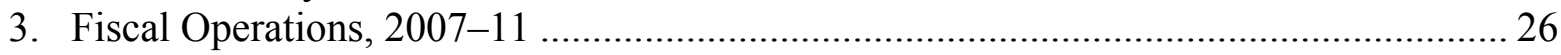

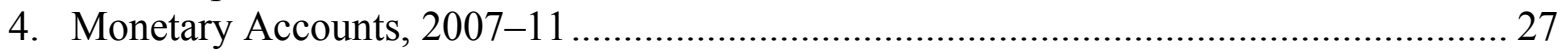

5. Medium-Term Framework and Balance of Payments, 2008-15 _............................. 28

6. Low Growth Scenario Under Unchanged Policies, 2008-15 ................................... 29

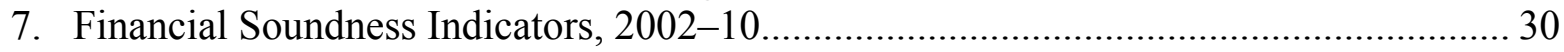

8. Indicators of External Vulnerability, 2005-09 ....................................................... 31

9. Public Sector Debt Sustainability Framework, 2007-15 .......................................... 32

10. External Debt Sustainability Framework, 2007-15 ............................................... 33

Annex

I. Russia's Experience with Capital Flows................................................................ 34 


\section{CRISIS Recovery}

\section{A. A Gradually Improving Economy}

The Russian economy is improving, but the recovery is fragile. Inflation has come down rapidly. High oil prices and a return of risk appetite have strengthened the balance of payments. Nonetheless, the banking system is still under strain and financial markets remain vulnerable to shifts in investor sentiment and oil price declines.

\section{Hit hard by the global financial crisis, the Russian economy contracted by} 7.9 percent in 2009. Domestic demand fell sharply in the first half of 2009, following plunging oil prices and an abrupt reversal of capital flows that brought a multi-year credit boom to an end. Private consumption and fixed investment declined strongly, with the effects on growth compounded by a large rundown of inventories. The contribution of net exports, meanwhile, turned positive as imports contracted.

\section{The economy has improved, but the} recovery remains fragile. After some temporary softness in the first quarter, shortterm indicators point to a strengthening of the recovery (Figure 1). While all components of demand now appear to be expanding, growth is becoming increasingly driven by consumption, reflecting to a large extent the recent 45 percent cumulative increase in pensions and other policy support.

\section{Inflation has been coming down}

rapidly. Against the background of a large output gap, falling food prices, and an appreciating ruble, headline inflation has fallen from 14 percent (y-o-y) in early 2009 to 6 percent in May 2010. Core inflation-which excludes administered prices as well as fruits and vegetables — has fallen to around $4 \frac{1}{4}$ percent.
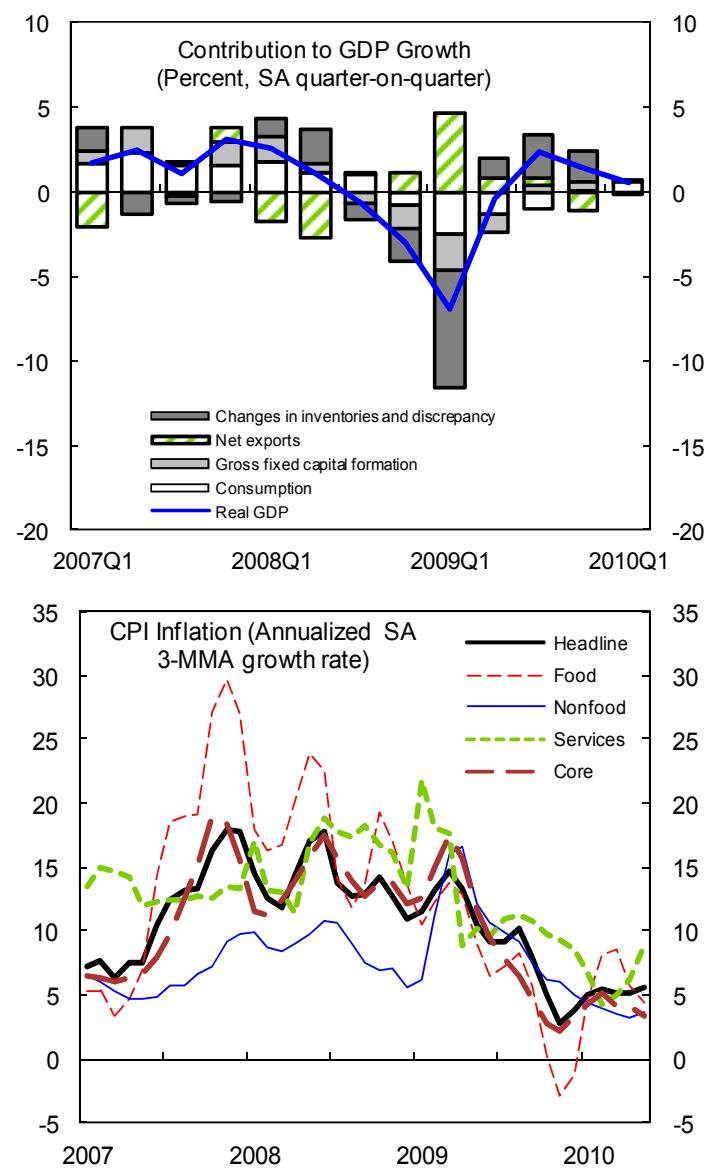
Figure 1. Russian Federation: Production Indicators, 2008-10

(Annualized quarter-on-quarter growth rate of seasonally adjusted 3-month moving average, unless otherwise indicated)

Following a weak Q1, monthly GDP estimates point to firming growth...

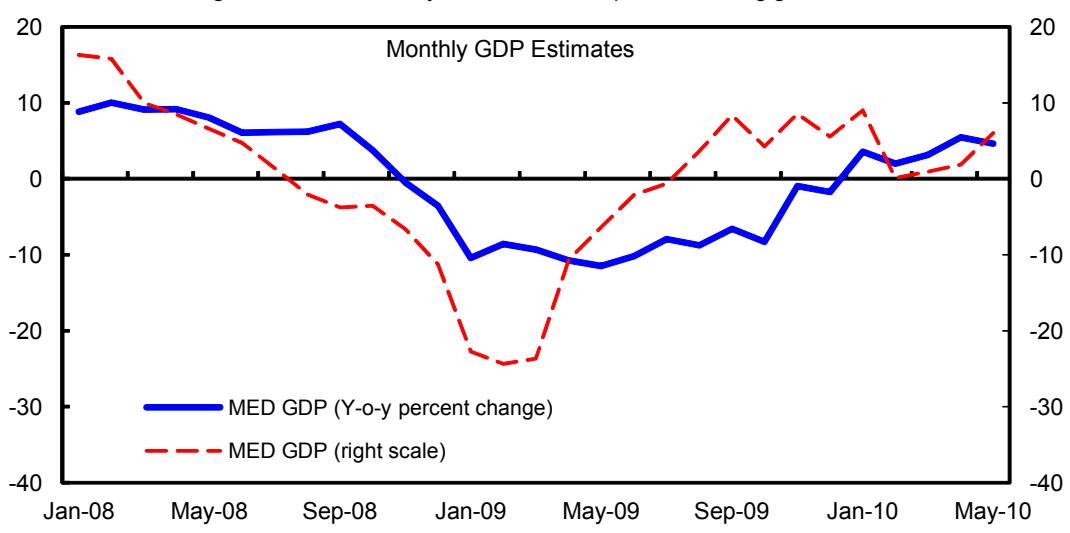

Industrial production has strengthened again recently ...

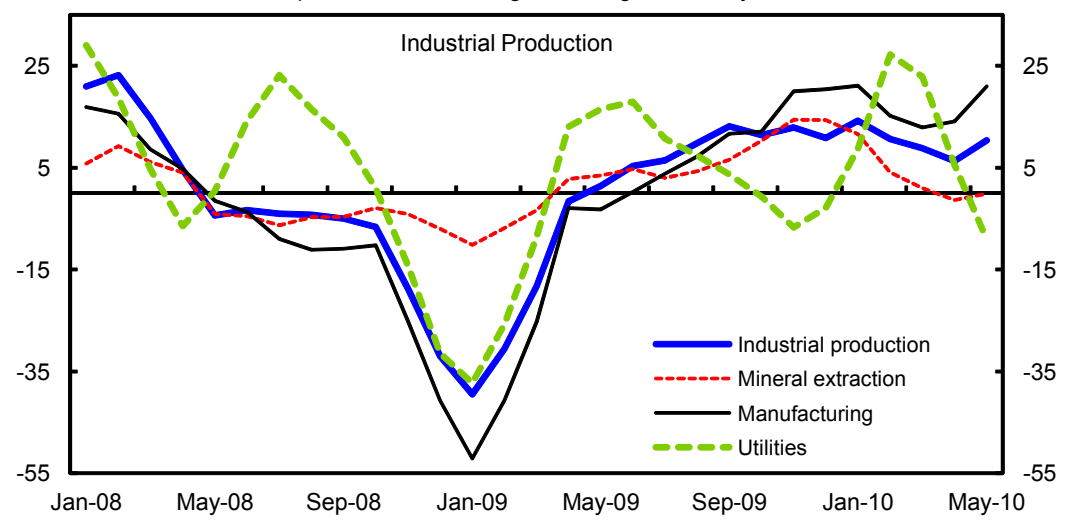

Sources: Rosstat; Ministry of Economy; and IMF staff calculations partly reflecting continued strong retail sales.
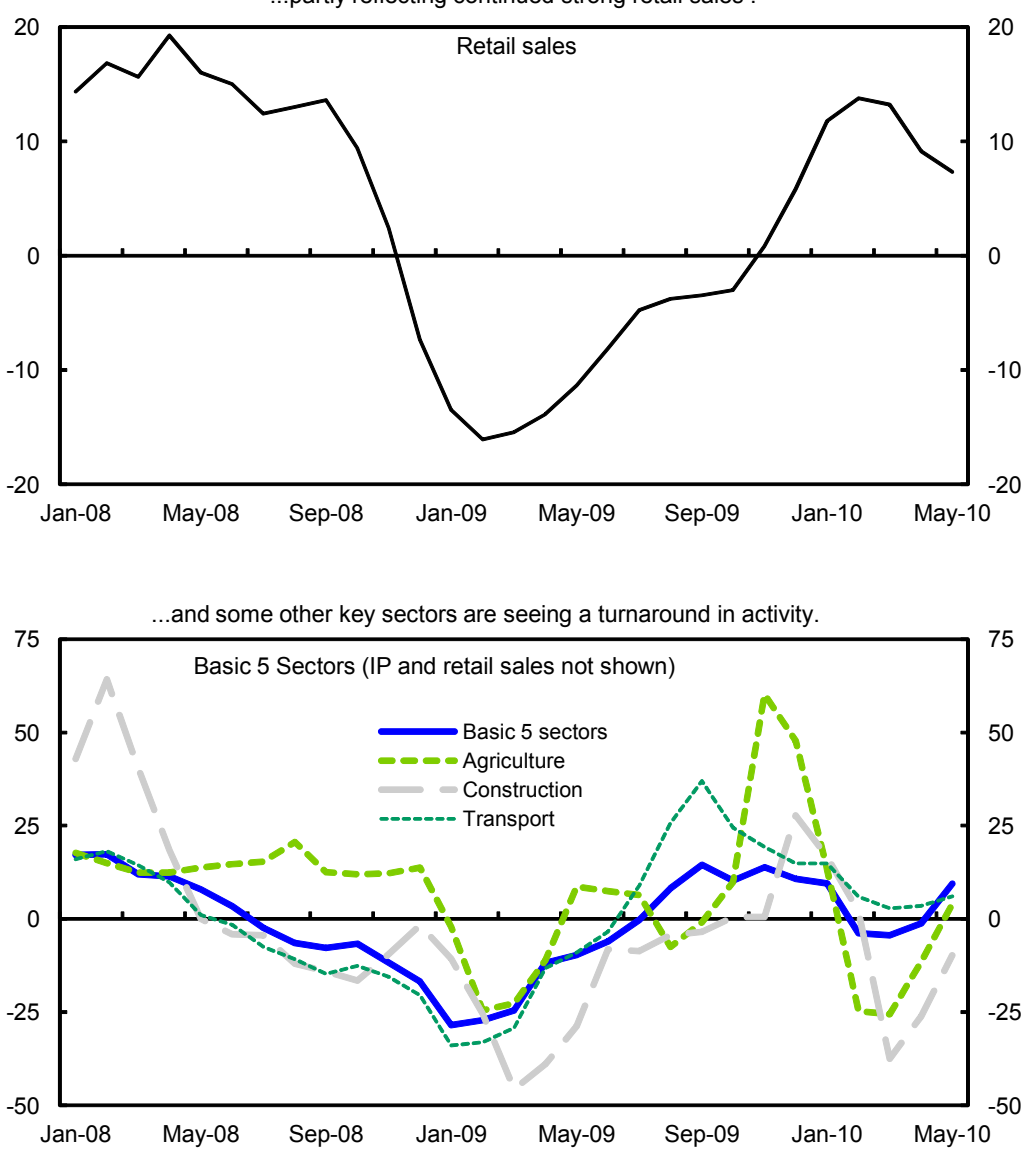


\section{Labor market conditions have}

improved. The unemployment rate, which shot up in the second half of 2008, has recently been coming down rapidly, to about $71 \frac{1}{2}$ percent in May from a peak of 9 percent. At the same time, real wages and real disposable income have strengthened, underpinning the recovery in private consumption.

\section{Following sharp deteriorations,} both the current and capital accounts have strengthened. The current account surplus fell to 4 percent of GDP in 2009,

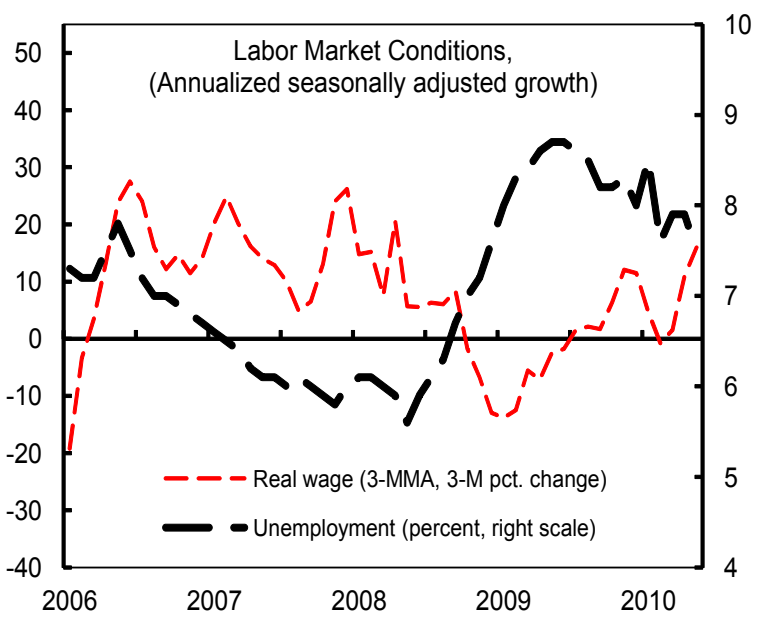

Sources: State Statistics Office; and IMF staff calculations. from about 6 percent in 2007 and 2008. On the export side, lower oil prices and weak external demand led to a 36 percent decline in export values. This, however, was partly offset by a 35 percent drop in import values that reflected the fall in domestic demand. The current account recovered in the second half of 2009 and preliminary data indicate that it strengthened appreciably in 2010 thus far, reflecting high oil prices and a continued recovery in export volumes. At the same time, the capital account has stabilized amid periods of intermittent outflows and inflows.

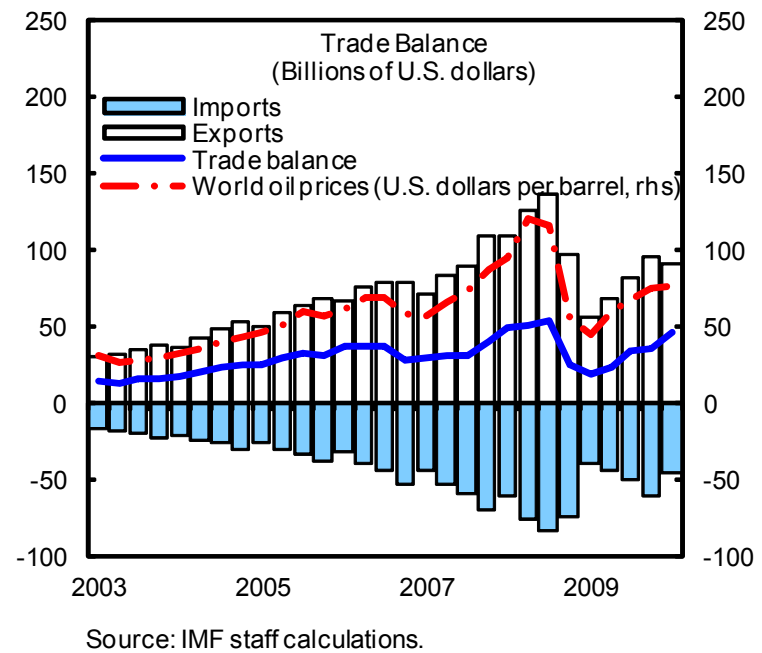

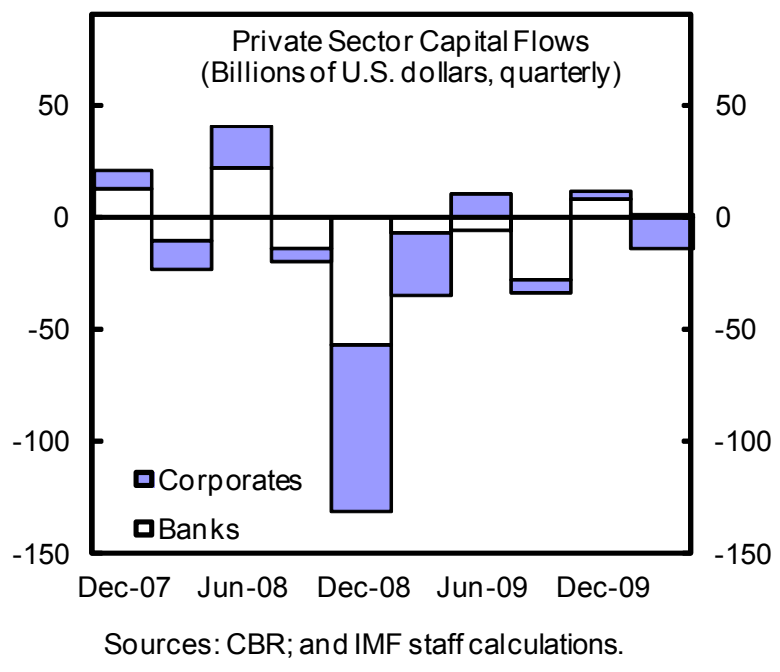

\section{The overall balance of payments has remained in surplus, and the ruble has} appreciated. Reserves increased by some $\$ 60$ billion over the past 12 months. The ruble has appreciated by about 20 percent in real effective terms since its trough in February 2009, bringing it broadly back to its pre-crisis level. Although the appreciation since the Fall 2009 CGER exercise exceeds the rise in long-term oil prices over the same period, the CGER estimates - as well as the mission's assessment — still suggest that the ruble is broadly in line with medium-term fundamentals. 
CGER Results, 2009-10

(Percent deviation from estimated equilbrium)

\begin{tabular}{lcc}
\hline & Fall 2009 & Spring 2010 \\
\hline Macro balance approach & -3 & -7 \\
External stability approach & -8 & 4 \\
ERER approach & -5 & 11 \\
Average & -5 & 3 \\
\hline
\end{tabular}

\section{Financial indicators rebounded in 2009 , but the recent turmoil has roiled}

markets. As global conditions recovered over the course of 2009, financial market indicators in Russia improved markedly. Russia's stock market index more than doubled last year, making it one of the best performers among emerging markets. Sovereign spreads, which had peaked at over 850 bps in late 2008, fell to below 140 bps in mid-April 2010. Since then, in the wake of the crisis in Europe and the renewed decline in oil prices, markets have been volatile: the ruble has depreciated by 7 percent against the dollar, Russian sovereign spreads have risen by some $120 \mathrm{bps}$, and the stock market surrendered its gains for the year (Figure 2).

8. The banking system is highly liquid, but banks have been strained by bad loans and credit has remained stagnant. Overdue loans have continued to rise and now stand at $61 / 2$ percent of total loans under Russian reporting standards. Reflecting weak demand for credit and the continuing efforts by banks to restructure their balance sheets, credit to the economy has remained largely unchanged in nominal terms since January 2009. There are signs, however, that the accumulation of overdue loans is now decelerating, and that banks are scaling back efforts to boost provisions and capital. Indeed, some of the larger banks, citing an improvement in asset quality, have signaled that they may release provisions to fund new loans later in the year. Although banks' pre-provision income was relatively healthy in 2009, falling interest rates have squeezed interest margins and increased pressure on banks to begin lending. In this context, credit growth picked up modestly in March and April, reflecting an improvement in credit demand and moderating credit supply constraints. 
Figure 2. Russian Federation: Financial Market Indicators, 2007-10
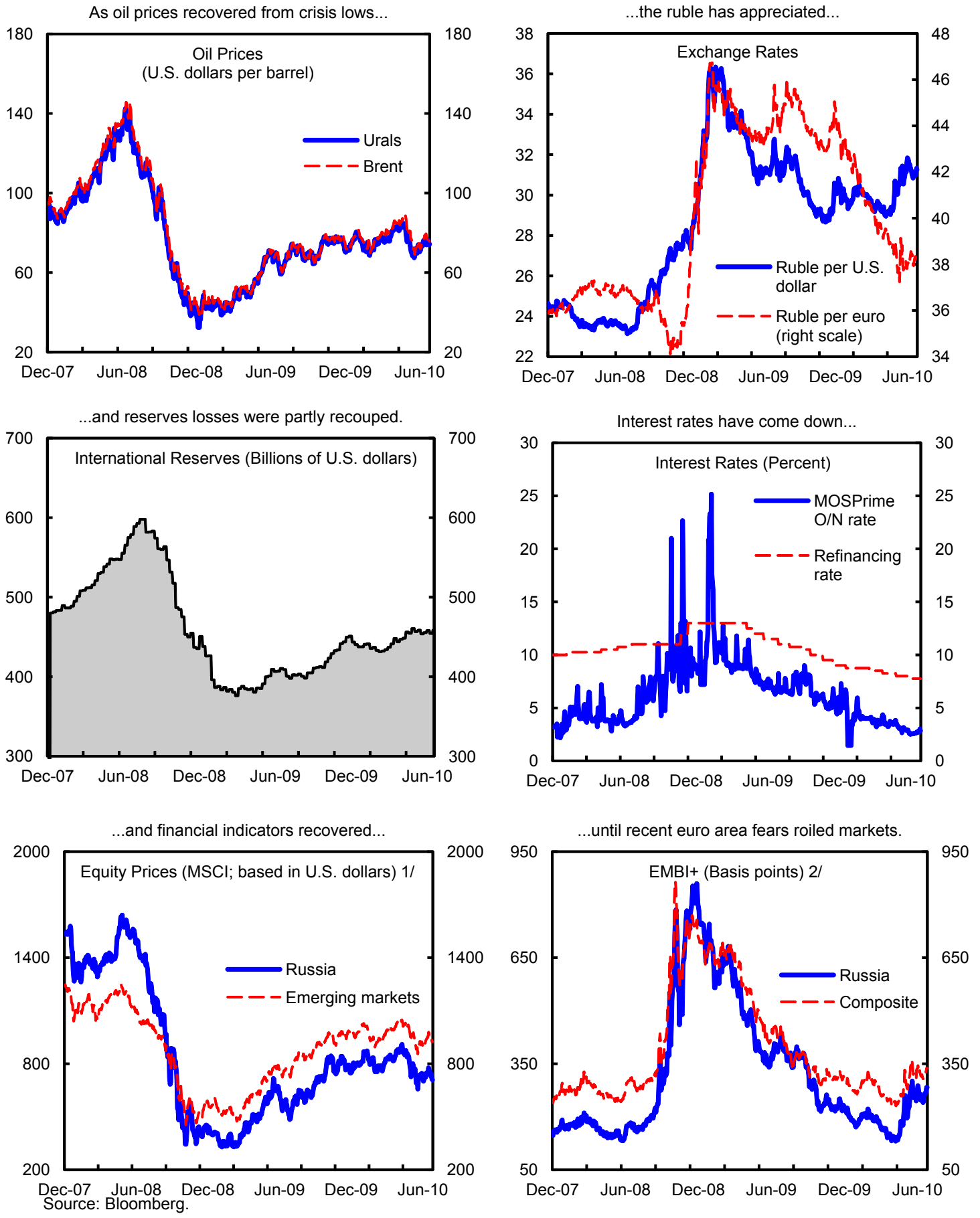

1/ The MSCI Emerging Markets Index is a commonly used float-adjusted market capitalization index designed to measure equity market performance in global emerging markets. It comprises Argentina, Brazil, Chile, China, Colombia, Czech Republic, Egypt, Hungary, India, Indonesia, Israel, Jordan, Korea, Malaysia, Mexico, Morocco, Pakistan, Peru, Philippines, Poland, Russia, South Africa, Taiwan, Thailand, Turkey and Venezuela. Based in U.S. Dollars, 1997=100.

$2 /$ Tracks total returns of external debt instruments of emerging markets with an outstanding face value of at least $\$ 500$ million. 


\section{B. Policy Response to the Recession}

The Russian authorities responded forcefully to the recession. ${ }^{1}$ The pre-crisis policy of taxing and saving much of the oil windfall created significant space for fiscal expansion, monetary easing, and extraordinary liquidity support to the banking system.

\section{Fiscal Policy}

9. There was a dramatic discretionary fiscal relaxation in 2009. The general government nonoil deficit increased from 81/4 percent of GDP in 2008 to 15 percent of GDP in 2009, almost entirely on account of higher spending. This was one of the largest fiscal stimuli in the G-20. However, much of the expansion was targeted at low-multiplier areas, such as strategic sectors and defense and security. Moreover, most of the stimulus was implemented in the second half of the year-too late to prevent a deep recession (Figure 3).

By end-2009, the underlying federal government nonoil balance was some 9 percent of GDP above both its precrisis level and the government's own Federal Budget Expenditure by Functional Classification, 2008-10

\begin{tabular}{lcccccc}
\hline & 2008 & 2009 & Change & 2010 & 2010 & 2010 \\
\cline { 5 - 7 } & & Est. & & Budget & Suppl. & Proj. \\
\hline & & & (Percent of GDP) & & \\
Total expenditures & 18.7 & 24.7 & 5.9 & 22.3 & 0.7 & 23.1 \\
National economy & 2.5 & 4.2 & 1.8 & 3.0 & 0.1 & 3.1 \\
Defense and security & 4.5 & 5.6 & 1.1 & 5.2 & 0.0 & 5.3 \\
General public issues & 2.0 & 2.1 & 0.1 & 2.7 & 0.0 & 2.5 \\
Social policies & 0.7 & 0.8 & 0.1 & 0.7 & 0.0 & 0.8 \\
Education & 0.9 & 1.1 & 0.2 & 0.9 & 0.0 & 0.9 \\
Health & 0.7 & 0.9 & 0.2 & 0.7 & 0.0 & 0.8 \\
Intragovernmental transfers & 6.4 & 9.2 & 2.8 & 8.4 & 0.4 & 9.0 \\
Other & 1.1 & 0.6 & -0.5 & 0.6 & 0.1 & 0.7 \\
\hline
\end{tabular}
medium-term target.

10. The headline deficit was easily financed. Russia's prudent past management of its oil wealth left the country with large international reserves and low public debt. This created room to monetize the deficit - which swung from a surplus of 4 $\frac{1}{4}$ percent of GDP in 2008 to a deficit of $6 \frac{1}{4}$ percent of GDP in 2009 - by drawing down the oil funds held at the CBR without significant risks to external stability. Russia's public debt ratio is below 11 percent.

\footnotetext{
${ }^{1}$ For additional detail on the authorities' immediate crisis response, see Russian Federation: 2009 Article IV Consultation - Staff Report; Staff Statement; Public Information Notice on the Executive Board Discussion (http://www.imf.org/external/pubs/cat/longres.cfm?sk=23176.0).
} 
Figure 3. Russian Federation: Selected Fiscal Indicators, 2008-10
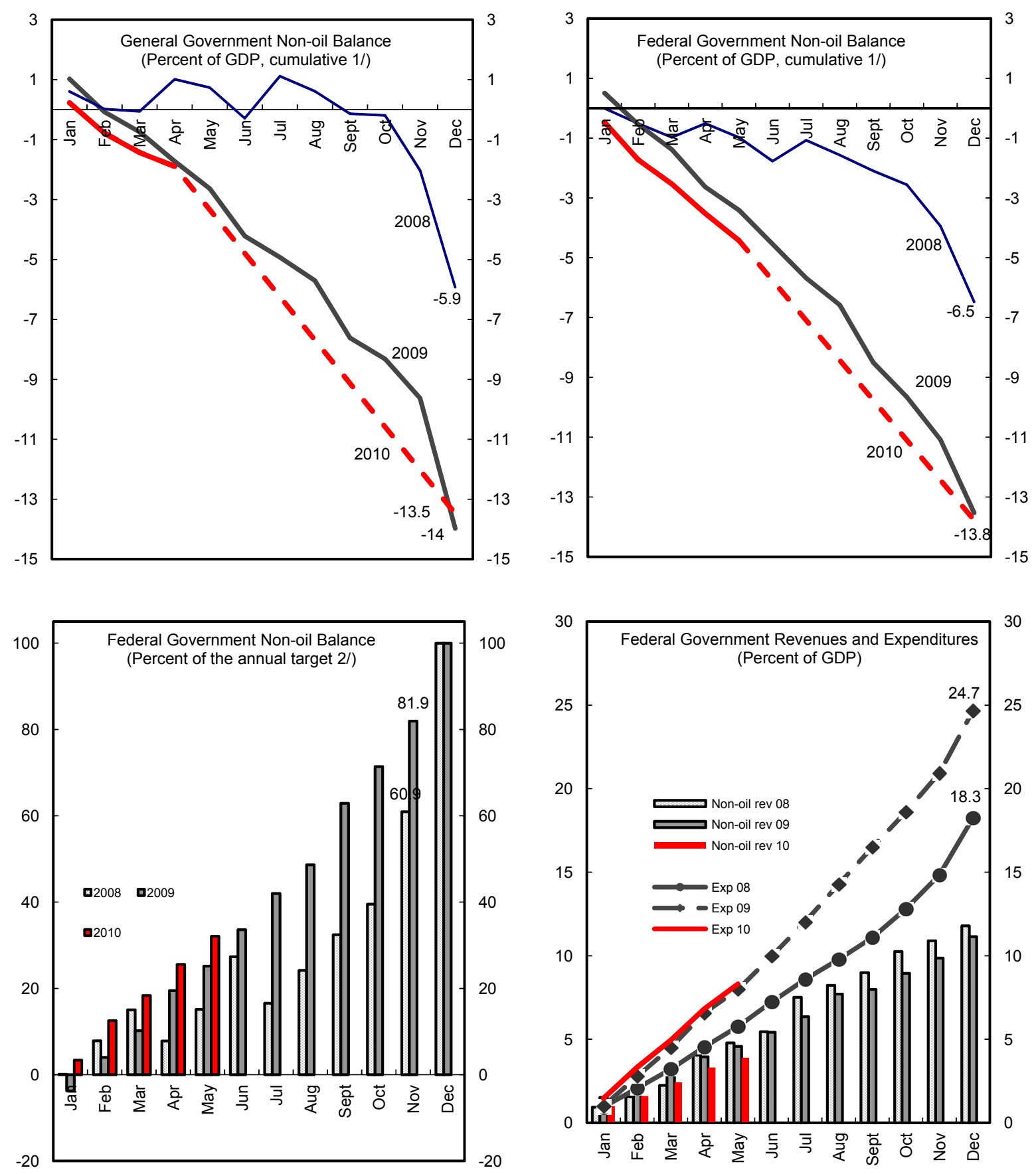

Sources: Russian authorities; and IMF staff estimations.

1/ Authorities' definition. Includes CIT on oil companies in the non-oil revenue. Dotted line is projection.

$2 /$ Cumulative monthly non-oil balance as a share of the actual and projected annual non-oil balance. 


\section{Monetary Policy}

11. Against the backdrop of a more stable external outlook and falling inflation, the CBR has steadily reduced interest rates. It cut its refinancing rate by 525 bps to $73 / 4$ percent from its peak in April 2009. However, given the uncertain economic outlook and reflecting increased risk aversion, nominal interest rates remained stubbornly high for most borrowers throughout much of 2009. In this context, the decline in inflation has turned average real interest rates positive for the first time in many years. Only recently have deposit and lending rates begun to fall more quickly. By contrast, interbank rates have remained within the CBR's policy corridor, reflecting the high liquidity of the banking sector (Figure 4).

12. The exchange rate has become more flexible. This has, however, occurred in the context of a weaker balance of payments and a sizeable output gap, which has reduced the tradeoff between inflation and nominal exchange rate objectives. Since March 2009, the ruble has appreciated by around 15 percent against the exchange rate basket, with short-run movements sometimes exceeding 4 percent in a single week. Nonetheless, the CBR continues to intervene to avoid abrupt changes in the exchange rate, while still allowing a markedly greater degree of day-to-day volatility. While a further increase in international reserves is not the goal of the CBR's interventions, it is clearly a byproduct of this policy in an environment of high oil prices, involving sterilization and opportunity costs. 
Figure 4. Russian Federation: Monetary Policy, 2007-10
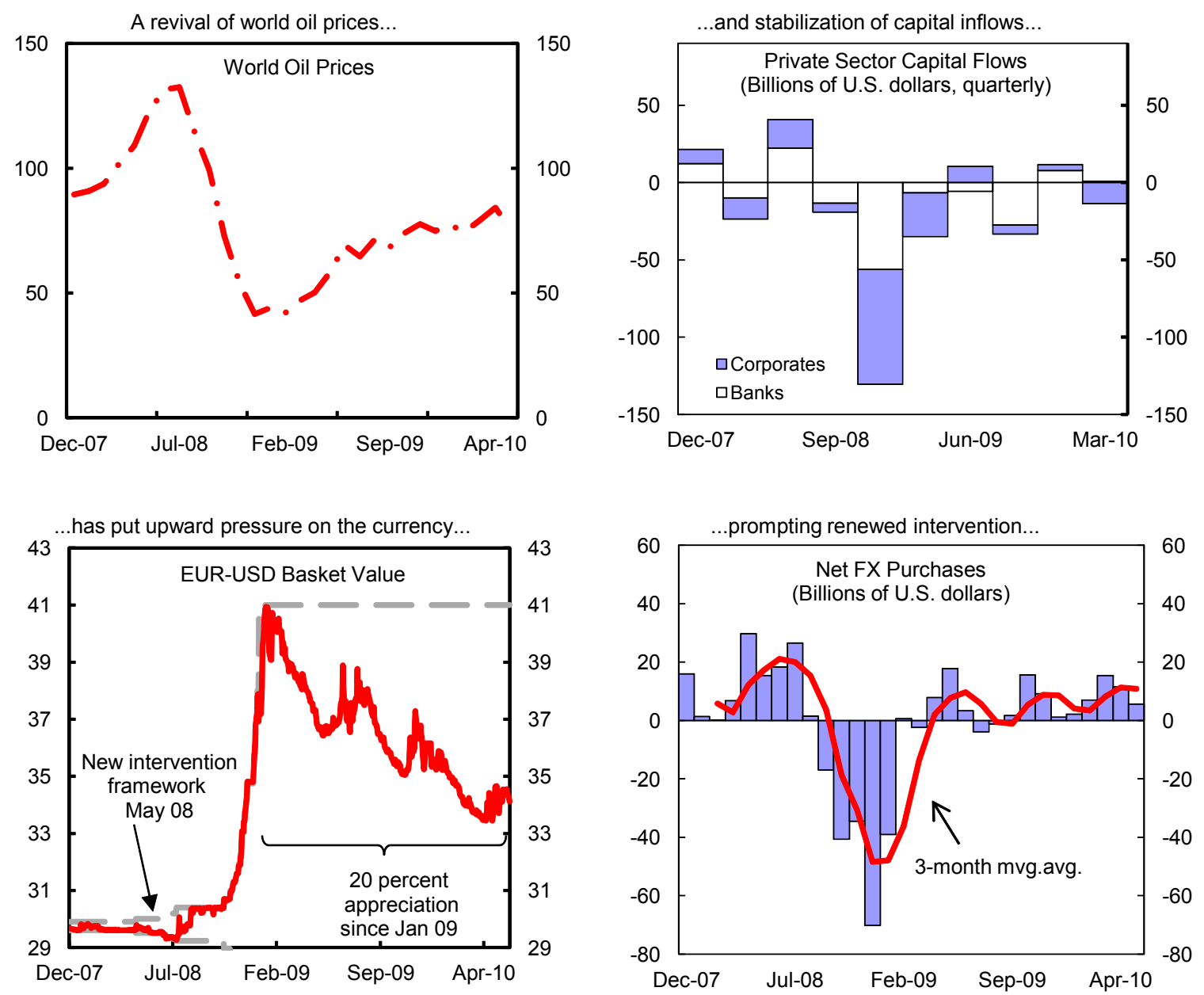

...and permitting an easing in interest rates.

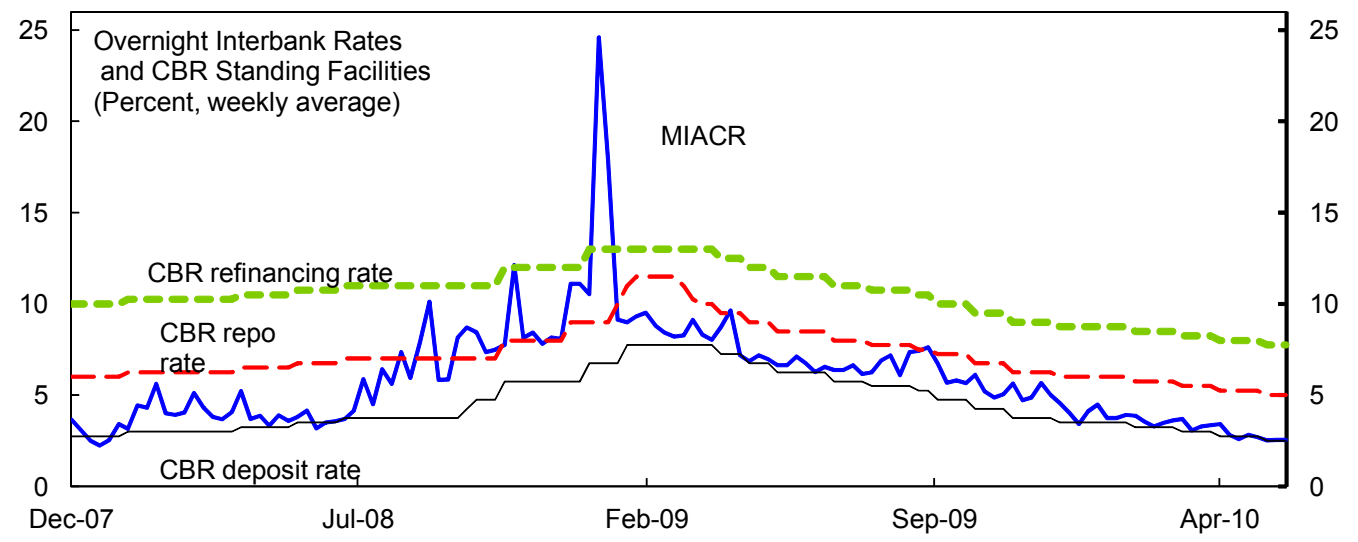

Sources: CBR; and IMF staff calculations. 


\section{Financial Sector Policy}

13. The authorities have been exiting from extraordinary liquidity support extended during the crisis. With banks highly liquid, repo demand has effectively disappeared, and banks have used excess funds to repay their debt to the CBR ahead of schedule. This withdrawal of liquidity, together with the issuance of new CBR bonds and a pick-up in money demand, largely sterilized the monetary impact of the fiscal expansion in 2009 (Figure 5). Also, one bank has partially repaid the public capital injection it received during the crisis.

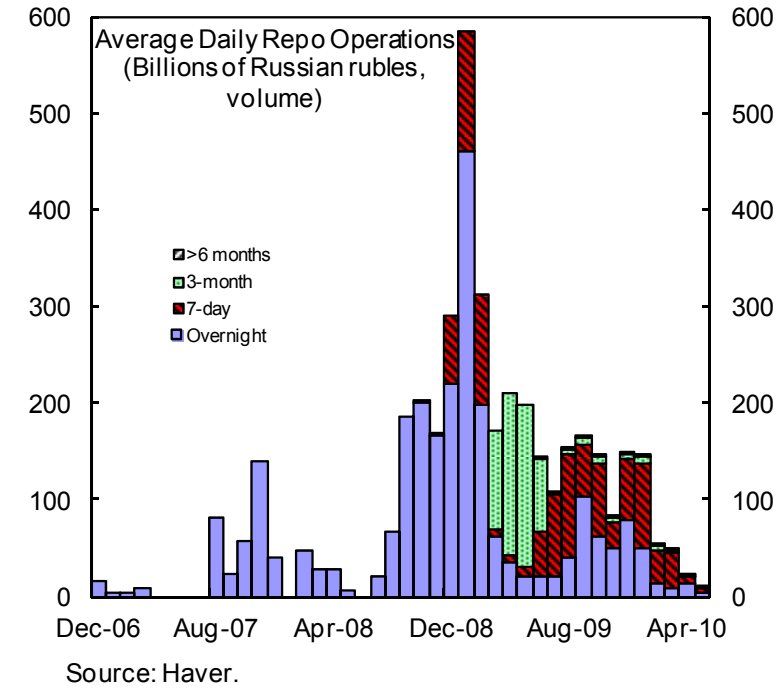

14. Other support mechanisms are also gradually being withdrawn. As of July, regulatory forbearance, in the form of easier provisioning requirements, ${ }^{2}$ will be gradually brought back in line with pre-crisis norms. Lending limits for uncollateralized loans were reduced in February, and interbank market guarantees are being unwound. Moreover, having expanded the "Lombard list" used for repo transactions during the crisis, the CBR intends to tighten eligibility over time. Collateral rules for nontraded assets used for CBR refinancing are also being strengthened. Finally, an earlier-planned public bank-recapitalization scheme has been scrapped. At the same time, the CBR stands ready to reactivate these facilities should the banking system come under renewed pressure in the face of adverse shocks.

\footnotetext{
${ }^{2}$ Under the relaxed loan classification requirements, a corporate (retail) loan became overdue if had been delinquent for 30 days ( 60 days) - up from 5 days (30 days) under the old rules. In addition, if a loan had been restructured, it could remain in its original classification category.
} 
Figure 5. Russian Federation: Liquidity Indicators, 2007-2010
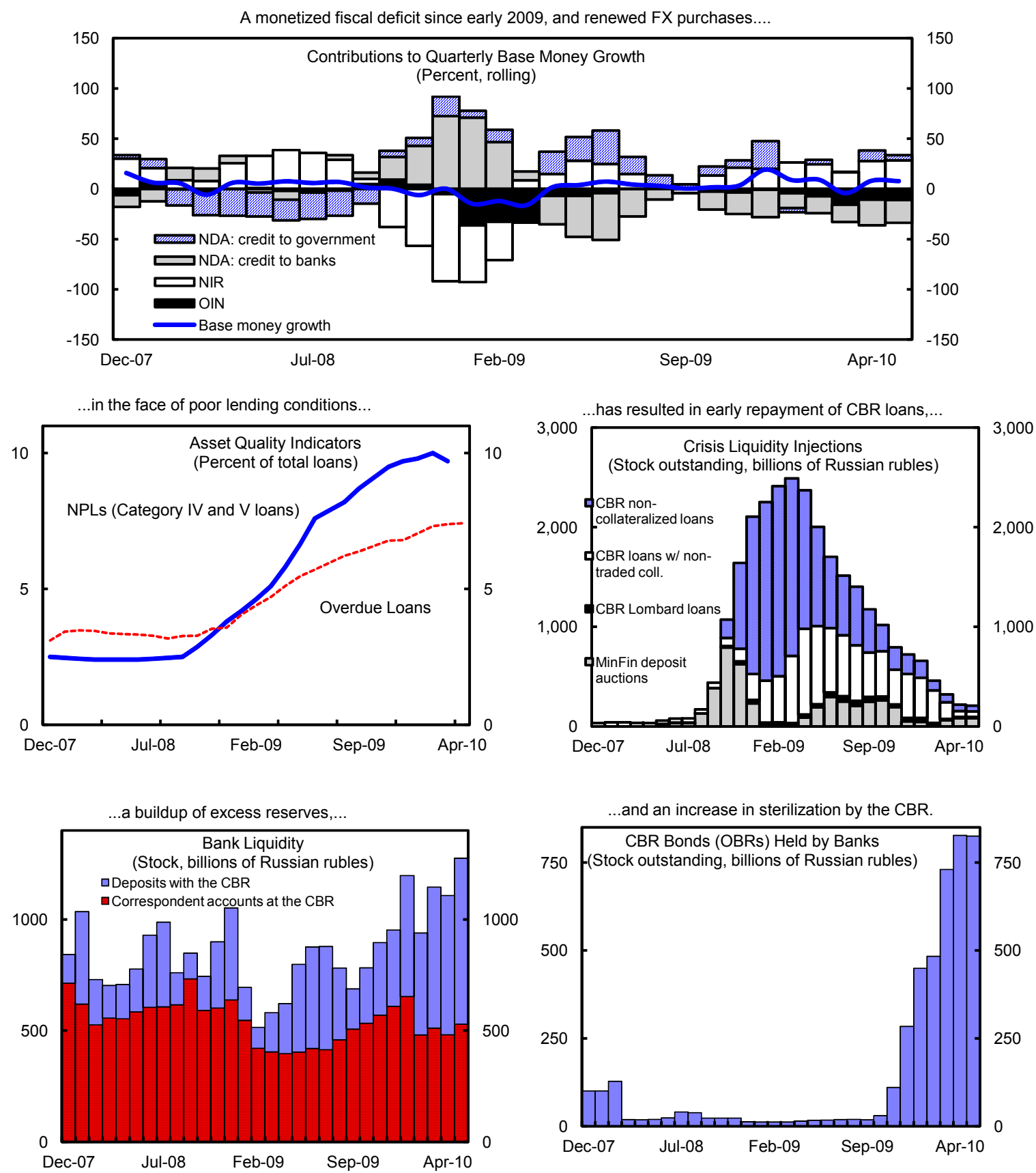

Sources: CBR; and IMF staff calculations. 


\section{NEAR-TERM OUTLOOK AND RISKS}

15. The near-term economic outlook is for a moderate recovery. While the recent rebound is still dependent on policy support, a self-sustained consumption-led recovery is set to gradually take hold, not least because the adjustment of bank balance sheets now appears to have run its course, with banks poised to cautiously expand lending. Gradually rising real wages and lower unemployment should provide additional support to consumption. As a result, GDP growth is projected to reach 41/4 percent in 2010, supported by a boost to consumption and a turn in the inventory cycle (and also reflecting large base effects). However, absent sustained increases in oil prices, underlying growth momentum is expected to recover only gradually, causing annual growth to fall back to around 4 percent in 2011. Reflecting the output gap, still-weak demand, and continued ruble appreciation, inflation is projected to remain subdued, reaching 6 percent (y-o-y) at end-2010 and 51/2 percent at end2011.

16. Short-term risks are broadly balanced. On the upside, more favorable external developments — particularly higher oil prices and greater capital inflows — or a more rapid recovery in credit could push growth higher. On the downside, external shocks - for example, those emanating from sovereign vulnerabilities in Europe with effects on oil prices or investor sentiment - present the key risk. There are few direct financial linkages, owing to the relatively modest role of foreign banks in Russia's financial system. However, an abrupt drop in oil prices and a retrenchment in risk appetite could result in larger-than-projected capital outflows given the liquidity overhang in the banking system. A worse-than-expected growth outcome in Russia would have knock-on effects throughout the region, mainly through remittances and trade (Box 1). 


\section{Box 1. Regional Spillovers from the Economic Slowdown in Russia*}

The deep recession in Russia had a substantial impact on its regional partners.

- $\quad$ Remittances. The remittance link is especially strong with the countries in the Caucasus and Central Asia (CCA), as well as Moldova, Belarus, and Ukraine. In the boom years preceding the crisis, Russia was an important employer of migrant workers from these countries, primarily in the flourishing construction sector. As Russia's real estate bubble burst, however, flows to these countries declined considerably. Individual remittances from Russia to the CIS dropped by more than 30 percent in total-Armenia, Georgia, the Kyrgyz Republic, Tajikistan, and Uzbekistan each experienced a drop in inflows, mainly from Russia, by up to a third in 2009 , while remittances to Moldova declined by almost 40 percent.

- $\quad$ Trade. Countries with strong trade links with Russia also saw a significant decline in their exports, owing to subdued demand in Russia. Exports to Russia from CIS countries started declining in the final quarter of 2008 and dropped by more than a third in 2009. Other neighboring countries experienced a similar patternFinland, for which Russia is the thirdlargest export market on account of transit trade, saw its exports to Russia drop by almost 50 percent in 2009 .

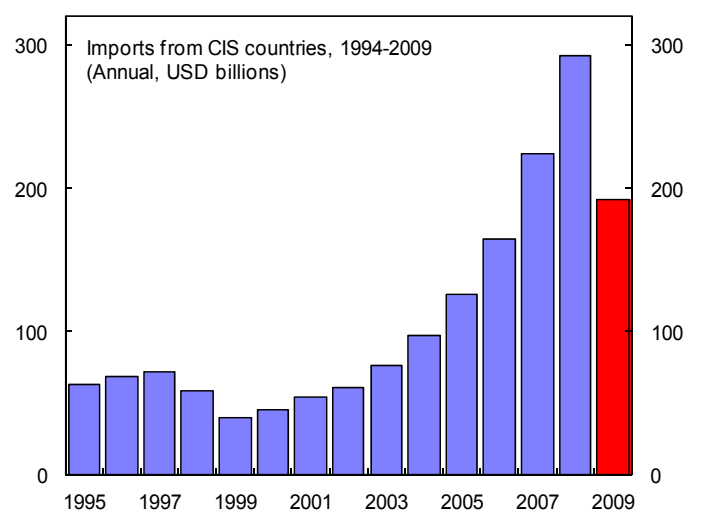

- Financial. Over the course of 2008-09, facing a significant depreciation of the Russian ruble vis-à-vis the dollar, many of Russia's trading partners were compelled to follow suit. Armenia, Kazakhstan, the Kyrgyz Republic, and Tajikistan all devalued their currencies by almost 25 percent. However, high dollarization levels in some of these countries left their financial sectors vulnerable to exchange-rate movements-depreciation impacted the balance sheets of local banks with FX exposures to unhedged borrowers, with negative knock-on effects on lending. Real credit growth has declined on average by over 60 percent in CCA countries since end-2007.

As Russia gradually recovers from the crisis, its regional partners stand to benefit. There are signs that the nascent recovery in the region is being partially supported by positive spillovers from Russia. The decline in remittances appears to be slowing, with some countries experiencing an increase in inflows during the first months of 2010, for example by 15 percent (y-o-y) in Tajikistan, and more than 10 percent in Armenia. Trade channels are also gradually normalizing - after a 10 percent decline in 2009, Moldova's exports to Russia rebounded by over 40 percent in January-April 2010.

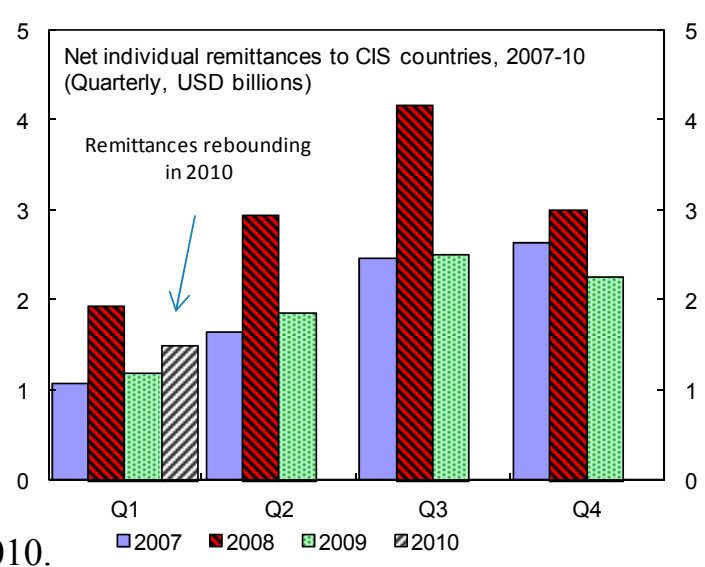

\footnotetext{
* Prepared by Andrew Tiffin and Daria Zakharova based on the May 2010 REO for Middle East and Central Asia.
} 


\section{Policy Discussions}

Medium-term fiscal consolidation is the overarching policy priority for Russia. With continued large oil price increases unlikely, achieving balanced growth will depend critically on an appropriately countercyclical fiscal policy aimed at mitigating pressures for real appreciation and inflation.

\section{The oil fund mechanism has served Russia well, creating room for a forceful} crisis response. The authorities took full advantage of the ample room for maneuver afforded by the prudent pre-crisis policy of taxing and saving much of the oil revenue and the attendant large reserves. Thus, even after a large drawdown of reserves and a sizeable fiscal stimulus, Russia faces no solvency or financing concerns. Still, the years before the crisis also saw important and growing weaknesses that were manifested in an increasingly inflationary policy mix. The steady rise in the nonoil deficit as more of the oil wealth was spent caused fiscal policy to become ever more procyclical, as private demand was very buoyant. Meanwhile, the attempt to resist the resulting upward pressures on the ruble through foreign exchange interventions caused monetary policy to become accommodative.

\section{Against this background, the key challenge facing Russia is to withdraw fiscal} stimulus as cyclical conditions normalize. There is a concern that, with spending pressures intensifying, fiscal policy could quickly become procyclical once again as the economy recovers, putting renewed pressure on the real exchange rate and inflation. Such concerns are heightened by the fact that most of the fiscal expansion relative to pre-crisis levels has involved permanent measures, notably large pension increases. This suggests that fiscal consolidation cannot be achieved unless urgent progress is made on long-stalled public sector reforms. Moreover, the authorities' room for maneuver is further constrained by the fact that - with limited prospects for large increases in oil prices over the medium term - the nexus of strong growth in investment, productivity, real wages, and consumption that powered Russia's pre-crisis growth is unlikely to return. In these circumstances, a return to an unfavorable macroeconomic policy mix of procyclical fiscal policy and monetary accommodation - coupled with continued slow progress on structural reforms-would likely take a larger toll in terms of rapid real appreciation, lower growth, and higher inflation than in the past.

\section{A. Fiscal Policy: Consolidation through Reform}

Increased pressures to spend more of the oil wealth, alongside a highly inflexible budget structure, suggest that withdrawing the fiscal stimulus is the key policy challenge facing the authorities. Meeting this challenge will require a reinvigoration of structural reforms.

19. Withdrawing the very large fiscal stimulus will be a formidable task. The underlying nonoil deficit of the federal government is projected to remain some 9 percent of GDP above its pre-crisis level in 2010. At the same time, the budget has become increasingly inflexible - three-quarters of the increase in the nonoil deficit relative to pre-crisis levels 
reflects higher permanent measures, with half of the increase attributable to higher pensions alone. Nonstatutory spending is now only 9 percent of GDP - equal to the size of the consolidation needed to reverse the stimulus and achieve the government's own long-term target for the nonoil deficit of 4.7 percent of GDP by 2015.

20. Fiscal policy is likely to be relaxed further. The original 2010-12 medium-term budget appropriately targeted a gradual withdrawal of stimulus - the nonoil deficit was slated to decline to $9 \frac{1}{2}$ percent of GDP in 2012. However, in June, the government passed a supplementary budget which - in addition to previously-announced tax expenditure measures - would lead to a slight increase in the federal nonoil deficit in 2010, compared to reduction of some $3 / 4$ percent of GDP implied by the original budget. A second supplementary budget - entailing civil service wage increases - could be passed in the fall. Moreover, the authorities appear to be revisiting the planned pace of medium-term consolidation.

Supplementary Budget for 2010

\begin{tabular}{lrr}
\hline Measure & Rub bn & \multicolumn{1}{c}{ GDP\% } \\
\hline Total supplementary expenditures & 325.5 & 0.7 \\
Additional transfers to pension fund & 150 & 0.3 \\
Housing for WWII veterans & 82.3 & 0.2 \\
Housing for military & 42.9 & 0.1 \\
Other & 50.3 & 0.1 \\
\hline
\end{tabular}

Sources: Budget documents; and IMF staff calculations.

\section{Staff recommended that the fiscal consolidation start now, and be stepped up}

in 2011-12. With recovery underway, and given the magnitude of the fiscal consolidation needed to reverse the stimulus, striking an appropriate balance between short-term cyclical considerations and medium-term consolidation suggests that the withdrawal of stimulus should begin in 2010. In this context, staff disagreed with the expansion of the federal government's nonoil balance implied by the 2010 supplementary budget, and warned against another supplement in the fall. In staff's view, the previously-planned target of reducing the nonoil deficit to $9 \frac{1}{2}$ percent of GDP by 2012 remains broadly consistent with the current outlook for economic activity. Looking further into the future, the target of a nonoil deficit of 4.7 percent of GDP implied by the government's long-term fiscal framework remains an appropriate long-term fiscal anchor.

\section{The authorities and staff agreed that fiscal consolidation could only be achieved through a reinvigoration of long-stalled public-sector reforms. However, such reforms} had been idle for several years and the authorities acknowledged that there was little momentum for restarting them at this stage. Nonetheless, they were hopeful that progress could be made following the elections in 2012. In this regard, they indicated that a gradual increase in the retirement age and a rationalization of social protection benefits through more rigorous means-testing were being contemplated. The authorities are also considering revenue measures. In particular, they saw scope to: (i) further raise excise taxes and the extraction tax on gas; (ii) introduce market-based valuation for property tax; and (iii) streamline tax-breaks and privileges. Staff expressed concern that delayed implementation of reforms would make it impossible to withdraw the stimulus in a timely manner, noting that the associated macroeconomic risks would increase as cyclical conditions improved. It 
agreed that an increase in the retirement age was needed to strengthen the viability of the pension system, and indicated that cross-country comparisons suggest that significant savings can be achieved in health and social protection without compromising the quality of service delivery. Staff welcomed the revenue measures under consideration, but noted that most of the adjustment would need to take place on the expenditure side, through reforms and reductions in discretionary spending.

\section{Staff and the authorities also concurred on the need to strengthen the fiscal policy framework.}

- $\quad$ Staff underscored that the policy of taxing and saving much of the oil wealth through the Reserve and National Welfare Funds had served Russia well, and created room for a large countercyclical response to the crisis and recession. Preserving this policy would be key to macroeconomic stability.

- $\quad$ The mission urged the authorities to avoid the use of supplementary budgets. Such budgets have been passed in every year since the 1998 crisis, reflecting persistent spending pressures. Since 2004, with the exception of the recent crisis, the changes implied by the supplementary budgets have invariably increased the procyclicality of fiscal policy.

- Staff encouraged the authorities to refocus fiscal policy on the nonoil deficit. Use of the nonoil deficit provides an anchor for fiscal policy, given the volatility of commodity prices. Moreover, to ensure an effective countercyclical fiscal response, focusing fiscal policy firmly on the nonoil deficit would help to ensure that spending does not rise and fall with commodity prices. In this regard, staff expressed concern about the use of less conservative oil prices in the 2011-13 medium-term budget.

- $\quad$ Ministry of Finance officials agreed that the supplementary budgets reflected underlying pressures to spend more of the oil wealth. Nonetheless, while acknowledging that such budgets had increased the procyclicality of fiscal policy, they noted that the Ministry of Finance had had some success in limiting spending pressures. Still, they concurred that it would be preferable to strengthen the fiscal policy framework by avoiding the use of supplementary budgets and focusing on the nonoil deficit. In the area of fiscal risk management, the authorities explained that they intend to develop a methodology for assessing the sustainability of borrowing by quasi-sovereign enterprises, reducing borrowing costs, and introducing limits on the size and profile of external borrowing.

\section{B. Monetary Policy: Focusing on Inflation}

The CBR's policy of allowing greater exchange rate flexibility is a welcome step toward focusing monetary policy more firmly on inflation control. However, the authorities' commitment to this policy remains to be tested. 
24. The authorities and staff agreed that the monetary easing cycle should now be paused. At its June meeting, the CBR kept policy interest rates unchanged. Staff concurred and suggested that the next move should likely involve initiating a tightening cycle. The authorities felt that, as yet, such a move was premature, and expressed concern about the possible impact of higher interest rates on capital inflows. However, they pointed out that monetary conditions were indeed being tightened - given the gradual unwinding of crisis support to the banking system - and that the CBR stood ready to raise reserve requirements, if necessary, in the event of a resurgence of inflation pressures. In this context, staff urged the authorities to aim for a further reduction in inflation from current levels. Finally, the CBR agreed that the continued monetization of the fiscal deficit would pose additional challenges to monetary policy, but considered these to be manageable. In this regard, CBR officials highlighted their recent success in sterilizing excess liquidity through the issuance of central bank bonds (OBRs).

25. Staff reiterated its recommendation that monetary policy be focused on inflation control, in the context of a flexible exchange rate. The mission welcomed the CBR's more flexible exchange rate policy, and stressed that low inflation would be critical in expanding the availability of long-term ruble financing and reducing dependence on foreign funding. However, with weak cyclical conditions and low capital inflows, the CBR's commitment to a flexible exchange rate policy still remained to be tested. In this regard, staff felt that the authorities' monetary policy framework was unclear. It expressed concern that - should pressures on the ruble intensify - the authorities might once again resort to a policy of resisting nominal appreciation, leading to rapid growth of money and credit. These concerns were heightened by the lack of a clearly articulated inflation objective. Indeed, CBR officials conceded that exchange-rate considerations might again be given priority if tensions arose between the objectives of achieving low inflation and limiting appreciation. They felt thatgiven Russia's dependence on global commodity prices - the economy was not yet ready to cope with the exchange rate volatility implied by a completely free float.

\section{The mission supported the authorities' technical preparations for an eventual} move to formal inflation targeting. Recent enhancements in the CBR's public communications were playing a key role in preparing the public for such a move. These included regular, preannounced monetary-policy meetings and the issuance of press releases describing the rationale for policy rate decisions. The CBR noted that they were steadily putting in place other key technical prerequisites for a successful transition to inflation targeting. However, in line with the view that the economy was not yet prepared for a flexible exchange rate policy, they did not foresee the adoption of formal inflation targeting in the near future.

\section{The authorities and staff agreed that the more flexible exchange-rate regime,} alongside cuts in policy interest rates, had helped deter speculative capital inflows. They concurred that a return of capital inflows to pre-crisis levels was unlikely. However, should persistent, large-scale inflows resume, the authorities noted that they might consider the reintroduction of differentiated reserve requirements - by residence and currency — to prevent 
the accumulation of vulnerabilities in the banking system. They were also taking steps to reduce tax incentives for foreign borrowing, and were discussing ways in which the borrowing plans of state-owned enterprises might be more closely aligned with the authorities' macroeconomic stabilization goals. Staff agreed that there were circumstancessuch as a period of surging inflows caused by persistent and large oil prices increaseswhere such measures, including capital controls, could be useful, but cautioned that they were likely to lose effectiveness over time and could have undesirable multilateral effects. It noted that exchange-rate flexibility should serve as a first line of defense against a renewed increase in capital inflows, alongside strengthened prudential regulations and supervision aimed at curtailing excessive credit growth (Annex). Both staff and the authorities agreed that reserves were adequate.

\section{Restoring the Health of the Banking System}

Restoring the banking system to health is critical to ensuring a sustained recovery in credit expansion. This will require decisive action to improve provisioning standards and enhance the CBR's supervisory powers.

\section{Despite improvements in recent years, weaknesses in the regulatory and} supervisory framework remain. Generous accounting and provisioning rules, and the lack of comprehensive consolidated supervisory powers, continue to make it difficult to gauge the extent of systemic risks, the severity of the deterioration of the loan portfolio, and the adequacy of capital. In particular, given the sizeable pool of nonperforming and restructured loans, some banks may not have sufficient provisions to deal with unexpected shocks. Indeed, the stock of bad assets is likely to weigh on profitability going forward, making banks vulnerable to an increase in interest rates or a deterioration in economic conditions.

29. Staff urged the authorities to improve provisioning standards. In the mission's view, strengthening the loan classification and provisioning system is essential to gaining a full understanding of banks' capital adequacy. In particular, loan risk assessment should be improved and provisioning should be made more forward-looking by taking into account likely future loan losses. Doing so may reduce reported capital adequacy - and in this event, undercapitalized financial institutions should be recapitalized, restructured, merged, or closed. To the extent that better provisioning leads to healthier loan portfolios over time, the risk that increases in interest rates would damage bank earnings and balance sheets will be reduced. While noting the mission's concerns, the authorities stressed that the situation in the banking system had stabilized - the accumulation of overdue loans had slowed; bank provisions had increased dramatically; and capital adequacy levels were high. Looking forward, therefore, although a few banks might run into problems, the vast majority would be able to handle shocks without much difficulty.

30. Staff welcomed the authorities' decision to unwind regulatory forbearance. The mission noted, however, that grandfathered loans would require close monitoring and an eventual return to stricter standards. The authorities concurred, but emphasized the 
importance of avoiding abrupt changes to provisioning or classification requirements. In this regard, they pointed out that most grandfathered loans had a relatively limited maturity, and so would naturally cease to benefit from forbearance in the near future.

\section{The authorities and staff agreed that the CBR should be afforded greater} supervisory powers. They concurred that priority should be given to enhancing the CBR's authority to conduct consolidated supervision - including over connected lending. Strengthening regulations on connected lending would be critical to compel appropriate disclosure, ensure that suitable (market) terms are applied to such loans, and enable the imposition of sanctions. The authorities noted that relevant legislation had been drafted or was under preparation in these areas, and that they were proactively analyzing the extent of connected lending in the banking system.

\section{Reinvigorating Structural Reforms}

Improving the investment climate remains the overarching structural reform priority for Russia. Absent reform, and in an environment of moderate oil price increases, potential growth is likely to be low.

32. Russia's economy remains heavily dependent on primary commodities. Structural reforms have stalled in recent years, although there are increasing calls to modernize the economy and reduce its dependence on oil. Russia's nontradable sector is vulnerable to overheating, given its low capacity, while the tradable sector has stagnated in recent years. The crisis has further increased the dominance of the state in Russia's economy, and reducing inefficient and weak enterprises' dependence on state support, accompanied by significant restructuring, will be a central, yet difficult, challenge in the years ahead.

\section{Staff raised concerns that potential growth could remain low absent structural}

reforms. Russia's labor force is shrinking and its demographic trends are not auspicious. Moreover, the unfavorable investment climate - confirmed by Russia's low ranking on international comparisons in this area-suggests that investment is likely to remain more subdued than in the pre-crisis years. Finally, the scope for further catch-up gains in productivity will inevitably decline over time. These factors point to the need for deep restructuring of the economy, which can only begin once the investment climate is significantly improved.

\section{In this context, staff stressed that the key structural reform priority is to}

improve the investment climate. Civil service and public administration reforms are needed to curtail the pervasive influence of government on economic decision making. Other reforms would help assure investors that property rights will be protected and that the playing field for investing is level. Moreover, moving ahead with the recently announced privatization program would be a useful step toward rolling back the increased state dominance of the past few years. Finally, WTO accession - alongside a reversal of crisis- 
related emergency trade measures - holds the promise of making the investment environment more predictable and rules-based, while reducing dependence on primary commodity sectors.

\section{StafF APPRAisAl}

35. The stabilization fund mechanism allowed a forceful response to the crisis. The pre-crisis policy of taxing and saving much of the oil windfall and the attendant large increase in reserves left significant scope for a vigorous response. Policy-makers took full advantage of the room for maneuver by providing a dramatic countercyclical fiscal stimulus, supported by monetary accommodation as the fiscal deficit was monetized. Moreover, they helped the private sector cover large unhedged foreign exchange exposures by providing massive liquidity injections and easing lending criteria, and above all by allowing a substantial reserve loss, before undertaking a large step-devaluation well into the crisis. This almost certainly averted severe distress in the banking system. Undoubtedly, the crisis has shown that the stabilization fund mechanism is serving Russia very well.

36. Looking forward, the main challenge is fiscal consolidation. With cyclical conditions set to gradually normalize, and with lower potential growth, the authorities should plan on fully withdrawing the large fiscal stimulus in the coming years. Given the scale of this stimulus - some 9 percent of GDP — striking an appropriate balance between short-term cyclical considerations and medium-term consolidation suggests that the withdrawal should have begun already in 2010. The further increase in the federal government's nonoil balance implied by the supplementary budget is, therefore, regrettable, and another supplement in the fall should be avoided. More worrisome, with most of the stimulus having taken the form of permanent measures — not least higher pensions — advancing long-stalled public sector reforms is now becoming critical to preventing renewed overheating and excessive real appreciation as private demand recovers. The continued lack of support for such reforms and the prospect of only limited, if any, progress before the 2011-12 elections pose major and increasing risks to macroeconomic stability going forward.

37. The fiscal framework needs to be strengthened. Supplementary budgets have been adopted every year since the 1998 crisis - in some years there have been several such budgets. With the exceptions of the recent crisis, the change implied by the supplementary budgets have, since 2004, invariably run counter to what would have been required from a cyclical perspective. Thus, to ensure an effective countercyclical fiscal stance and anchor fiscal policy over the medium term, the authorities should eschew the use of supplementary budgets, and firmly focus annual and medium-term budgets on the nonoil deficit.

\section{Monetary policy should give priority to controlling inflation, not the exchange}

rate. The monetary easing cycle has appropriately been put on hold, and the next move should likely involve initiating a tightening cycle. The increased flexibility of the exchange rate during the past year is much welcome. However, the commitment to a flexible exchange rate policy remains to be tested in an environment that involves a sharper trade-off between inflation and the nominal exchange rate objectives. The mission's discussions suggest that 
the CBR is still not ready to commit fully to giving priority to inflation control. Risks in this regard would increase significantly going forward absent decisive action to reduce public expenditures.

39. Strengthening banking supervision is critical. Much progress has been achieved already, but loan risk assessment should be strengthened further and provisioning should be made more forward-looking. Moreover, the CBR should be afforded greater supervisory powers, particularly with respect to consolidated supervision and connected lending, which remains a potentially serious threat. Given the significant stock of international reserves, the authorities are well-positioned to continue to handle emerging threats to financial stability. Staff's main concern is that failure to decisively deal with the overhang of nonperforming and restructured loans will deter economic growth by hampering banks' ability to expand credit on a sustained basis and by directing available resources to struggling clients, away from dynamic enterprises seeking to boost investment.

40. A key priority remains reinvigorating structural reforms. With a shrinking labor force, adverse demographic trends, an unfavorable investment climate, and inevitably declining scope for further catch-up gains in productivity, post-crisis potential output growth is likely to be lower than pre-crisis levels. This points to the need for rapid and decisive action to advance structural reforms, with a focus on improving the investment climate and boosting the potential for productivity gains. Progress toward WTO accession is therefore welcome, as it, coupled with a reversal of emergency trade restrictions imposed during the crisis, would help to make the investment environment more predictable and rules-based.

41. The overarching challenge facing Russia is to ensure that consumption of its immense oil wealth does not get ahead of the expansion of its still-limited productive capacity outside the primary commodity sectors. Russia's record in this regard prior to the recent crisis was somewhat disappointing as the steady increase in the nonoil deficit in the face of buoyant private demand, combined with stalled structural reforms, caused rapid real appreciation and attendant signs of "Dutch Disease." Encouragingly, the sharp contraction in output as a result of the crisis, and the prospect — absent another prolonged period of rapidly growing oil prices - of Russia's emerging from the crisis with lower potential growth, are fuelling calls for change. Preventing an overvalued exchange rate by taxing and saving oil revenues, while moving decisively to strengthen the investment climate, remain key to modernization and diversification of the Russian economy. 
Table 1. Russian Federation: Selected Macroeconomic Indicators, 2007-11

\begin{tabular}{|c|c|c|c|c|c|}
\hline & \multirow[t]{2}{*}{2007} & \multirow[t]{2}{*}{2008} & \multirow{2}{*}{$\frac{2009}{\text { Estimate }}$} & 2010 & 2011 \\
\hline & & & & \multicolumn{2}{|c|}{ Projections } \\
\hline & & \multicolumn{4}{|c|}{ (Annual percent change) } \\
\hline \multicolumn{6}{|l|}{ Production and prices } \\
\hline Real GDP & 8.1 & 5.6 & -7.9 & 4.3 & 4.1 \\
\hline \multicolumn{6}{|l|}{ Consumer prices } \\
\hline Period average & 9.0 & 14.1 & 11.7 & 6.2 & 5.7 \\
\hline End of period & 11.9 & 13.3 & 8.8 & 6.0 & 5.4 \\
\hline GDP deflator & 14.4 & 18.0 & 2.3 & 8.9 & 6.6 \\
\hline Unemployment rate & 6.1 & 6.4 & 8.4 & 7.8 & 7.5 \\
\hline & \multicolumn{5}{|c|}{ (Percent of GDP) } \\
\hline \multicolumn{6}{|l|}{ Public sector } \\
\hline \multicolumn{6}{|l|}{ General government } \\
\hline Overall balance & 6.8 & 4.3 & -6.2 & -5.6 & -3.1 \\
\hline Revenue & 39.8 & 38.6 & 34.4 & 34.1 & 35.0 \\
\hline Expenditures & 33.1 & 34.3 & 40.6 & 39.8 & 38.0 \\
\hline Primary balance & 7.3 & 4.8 & -5.6 & -4.9 & -2.2 \\
\hline Nonoil balance & -3.9 & -8.3 & -15.0 & -14.6 & -11.5 \\
\hline Nonoil balance excl. one-off receipts $1 /$ & -6.2 & -8.3 & -15.4 & -14.6 & -11.5 \\
\hline \multicolumn{6}{|l|}{ Federal government } \\
\hline Overall balance & 6.1 & 3.5 & -5.9 & -5.9 & -3.4 \\
\hline Nonoil balance & -3.0 & -7.6 & -13.7 & -13.9 & -10.9 \\
\hline \multirow[t]{2}{*}{ Nonoil balance excl. one-off receipts $1 /$} & -5.3 & -7.6 & -14.1 & -13.9 & -10.9 \\
\hline & \multicolumn{5}{|c|}{ (Annual percent change) } \\
\hline \multicolumn{6}{|l|}{ Money } \\
\hline Base money & 33.1 & 2.9 & 7.4 & 19.1 & 17.1 \\
\hline Ruble broad money & 47.5 & 1.7 & 16.3 & 26.9 & 18.6 \\
\hline Credit to the economy & 48.5 & 37.8 & 1.6 & 11.3 & 12.4 \\
\hline \multicolumn{6}{|l|}{ External sector } \\
\hline Export volumes & 4.4 & -2.6 & -7.9 & 8.3 & 4.9 \\
\hline Oil & 5.4 & -2.6 & 3.0 & 1.8 & 1.6 \\
\hline Gas & -5.4 & 1.8 & -13.8 & 12.0 & -0.9 \\
\hline Non-energy & 6.7 & -4.4 & -18.5 & 16.4 & 11.0 \\
\hline \multirow[t]{2}{*}{ Import volumes } & 25.1 & 11.1 & -30.0 & 17.4 & 14.2 \\
\hline & \multicolumn{5}{|c|}{ (Billions of U.S. dollars; unless otherwise indicated) } \\
\hline \multicolumn{6}{|l|}{ External sector } \\
\hline Total merchandise exports, f.o.b & 354.4 & 471.6 & 303.4 & 380.6 & 408.9 \\
\hline Total merchandise imports, f.o.b & -223.5 & -291.9 & -191.8 & -238.0 & -271.9 \\
\hline External current account & 77.0 & 103.7 & 49.0 & 66.9 & 60.5 \\
\hline External current account (percent of GDP) & 5.9 & 6.2 & 4.0 & 4.5 & 3.6 \\
\hline \multicolumn{6}{|l|}{ Gross international reserves } \\
\hline Billions of U.S. dollars & 478.8 & 427.1 & 439.0 & 478.4 & 516.6 \\
\hline Months of imports $2 /$ & 20.3 & 14.0 & 20.8 & 18.3 & 17.4 \\
\hline Percent of short-term debt & 221 & 289 & 298 & 400 & 375 \\
\hline \multicolumn{6}{|l|}{ Memorandum items: } \\
\hline Nominal GDP (billions of rubles) & 33,258 & 41,445 & 39,064 & 44,360 & 49,190 \\
\hline Nominal GDP (billions of U.S. dollars) & 1,305 & 1,671 & 1,240 & 1,488 & 1,690 \\
\hline Exchange rate (rubles per U.S. dollar, period average) & 25.6 & 24.9 & 31.7 & $\ldots$ & $\ldots$ \\
\hline World oil price (U.S. dollars per barrel, WEO) & 71.1 & 97.0 & 61.8 & 75.3 & 77.5 \\
\hline Urals crude oil spot price (U.S. dollars per barrel) & 69.3 & 94.4 & 61.2 & 73.1 & 75.3 \\
\hline Real effective exchange rate (average percent change) & 5.6 & 6.6 & -6.6 & $\ldots$ & $\ldots$ \\
\hline
\end{tabular}

Sources: Russian authorities; and IMF staff estimates.

1/ Excludes one-off tax receipts from Yukos in 2007 and one-off transfers from Nanotechnology and Housing Funds in 2009.

2/ In months of imports of goods and non-factor services. 
Table 2. Russian Federation: Balance of Payments, 2007-11 (Billions of U.S. dollars, unless otherwise indicated)

\begin{tabular}{|c|c|c|c|c|c|}
\hline & \multirow[t]{2}{*}{2007} & \multirow[t]{2}{*}{2008} & \multirow{2}{*}{$\frac{2009}{\text { Estimate }}$} & 2010 & 2011 \\
\hline & & & & \multicolumn{2}{|c|}{ Projections } \\
\hline Current Account & 77.0 & 103.7 & 49.0 & 66.9 & 60.5 \\
\hline Trade Balance & 130.9 & 179.7 & 111.6 & 142.6 & 137.0 \\
\hline Exports & 354.4 & 471.6 & 303.4 & 380.6 & 408.9 \\
\hline Non-energy & 135.8 & 161.5 & 112.7 & 149.6 & 167.9 \\
\hline Energy & 218.6 & 310.1 & 190.7 & 231.0 & 241.0 \\
\hline Oil & 173.7 & 241.0 & 148.7 & 186.7 & 195.7 \\
\hline Gas & 44.8 & 69.1 & 42.0 & 44.2 & 45.3 \\
\hline Imports & -223.5 & -291.9 & -191.8 & -238.0 & -271.9 \\
\hline Services & -19.6 & -24.3 & -19.9 & -23.8 & -28.8 \\
\hline Income & -30.8 & -48.9 & -40.2 & -47.7 & -36.6 \\
\hline Public sector interest (net) & 16.1 & 17.4 & 6.3 & 5.3 & 7.9 \\
\hline Other sectors & -46.8 & -66.3 & -46.6 & -53.0 & -44.5 \\
\hline Current transfers & -3.5 & -2.8 & -2.5 & -3.9 & -4.2 \\
\hline Capital and financial account & 85.7 & -131.0 & -43.6 & -27.6 & -22.3 \\
\hline Capital transfers & -10.2 & 0.7 & -11.4 & -11.4 & -11.4 \\
\hline \multicolumn{6}{|l|}{ Financial accounts } \\
\hline Federal government & 0.2 & -9.1 & 24.8 & 3.1 & 2.9 \\
\hline Portfolio investment & -3.9 & -6.5 & 3.8 & 4.7 & 4.3 \\
\hline Loans & -5.2 & -2.3 & -3.4 & -1.7 & -1.4 \\
\hline Other investment & 9.3 & -0.3 & 24.4 & 0.0 & 0.0 \\
\hline Local governments & -0.1 & -0.1 & 0.4 & -0.1 & -0.1 \\
\hline Private sector capital & 95.9 & -122.6 & -57.5 & -19.1 & -13.7 \\
\hline Direct investment & 9.2 & 19.4 & -7.3 & 0.0 & 7.5 \\
\hline Portfolio investment & 10.9 & -28.6 & -7.0 & -3.6 & 0.0 \\
\hline Other investment, commercial banks & 29.4 & -55.3 & -29.0 & 5.0 & 5.2 \\
\hline Assets & -19.9 & -57.7 & 21.8 & 5.0 & 5.2 \\
\hline Liabilities (loans, deposits, etc.) & 49.3 & 2.4 & -50.8 & 0.0 & 0.0 \\
\hline Loans, corporations & 90.3 & 48.8 & 1.6 & 0.0 & 0.0 \\
\hline Disbursements & 171.5 & 170.8 & 81.8 & 89.4 & 66.6 \\
\hline Amortizations & -81.2 & -122.0 & -80.2 & -89.4 & -66.6 \\
\hline Other private sector capital flows & -43.8 & -106.9 & -15.8 & -20.6 & -26.5 \\
\hline Errors and omissions, net & -13.9 & -11.6 & -1.5 & 0.0 & 0.0 \\
\hline Overall balance & 148.9 & -38.9 & 3.9 & 39.3 & 38.2 \\
\hline Financing & -148.9 & 38.9 & -3.9 & -39.3 & -38.2 \\
\hline Net international reserves & -148.9 & 38.9 & -3.4 & -39.3 & -38.2 \\
\hline Arrears and rescheduling & 0.0 & -0.1 & -0.6 & 0.0 & 0.0 \\
\hline \multicolumn{6}{|l|}{ Memorandum items: } \\
\hline Current account (percent of GDP) & 5.9 & 6.2 & 4.0 & 4.5 & 3.6 \\
\hline Non-energy current account (percent of GDP) & -10.8 & -12.4 & -11.4 & -11.0 & -10.7 \\
\hline Gross reserves $1 /$ & 478.8 & 427.1 & 439.0 & 478.4 & 516.6 \\
\hline (in months of imports of GNFS) & 20.3 & 14.0 & 20.8 & 18.3 & 17.4 \\
\hline (percent of short-term debt) 2/ & 221.5 & 289.2 & 297.8 & 399.8 & 374.8 \\
\hline Net private capital flows (percent of exports of GNFS) & 24.4 & -23.4 & -16.6 & -4.4 & -3.0 \\
\hline Net private capital flows, banks & 45.8 & -56.9 & -36.7 & 2.4 & 2.7 \\
\hline Public external debt service payments $3 /$ & 10.5 & 8.4 & 6.0 & 5.3 & 5.9 \\
\hline (percent of exports of goods and services) & 2.7 & 1.6 & 1.7 & 1.2 & 1.3 \\
\hline Public external debt 4/ & 46.4 & 32.8 & 45.9 & 48.9 & 51.7 \\
\hline (percent of GDP) & 3.6 & 2.0 & 3.7 & 3.3 & 3.1 \\
\hline Private external debt & 424.7 & 447.7 & 425.7 & 425.7 & 431.2 \\
\hline (percent of GDP) & 32.7 & 26.8 & 34.6 & 28.6 & 25.5 \\
\hline Total external debt & 471.0 & 480.5 & 471.6 & 474.6 & 482.9 \\
\hline (percent of GDP) & 36.2 & 28.8 & 38.3 & 31.9 & 28.6 \\
\hline World oil price (U.S. dollars per barrel, WEO) & 71.1 & 97.0 & 61.8 & 75.3 & 77.5 \\
\hline Urals oil price (U.S. dollars per barrel) & 69.3 & 94.4 & 61.2 & 73.1 & 75.3 \\
\hline
\end{tabular}

Sources: Central Bank of Russia; and IMF staff estimates.

1/ Excluding repos with non-residents to avoid double counting of reserves. Including valuation effects.

2/ Excludes arrears.

$3 /$ Net of rescheduling.

4 / Includes indebtness of repos by the monetary authorities. 
Table 3. Russian Federation: Fiscal Operations, 2007-11

(Percent of GDP)

\begin{tabular}{|c|c|c|c|c|c|}
\hline & 2007 & 2008 & 2009 & $20101 /$ & 2011 \\
\hline & & & & \multicolumn{2}{|c|}{ Projections } \\
\hline \multicolumn{6}{|l|}{ General government } \\
\hline $\begin{array}{l}\text { Total revenue; of which: } \\
\text { Oil revenue } \\
\text { Non-oil revenue }\end{array}$ & $\begin{array}{l}39.8 \\
10.6 \\
29.2\end{array}$ & $\begin{array}{l}38.6 \\
12.6 \\
26.1\end{array}$ & $\begin{array}{c}34.4 \\
8.8 \\
25.5\end{array}$ & $\begin{array}{c}34.1 \\
8.9 \\
25.2\end{array}$ & $\begin{array}{l}35.0 \\
8.4 \\
26.6\end{array}$ \\
\hline $\begin{array}{l}\text { Corporate profit tax } \\
\text { Personal income tax } \\
\text { VAT } \\
\text { Excises } \\
\text { Custom tariffs } \\
\text { Resource extraction tax } \\
\text { Social security taxes } \\
\text { Other revenue }\end{array}$ & $\begin{array}{l}6.5 \\
3.8 \\
6.8 \\
0.9 \\
7.2 \\
4.0 \\
5.6 \\
5.0\end{array}$ & $\begin{array}{l}6.1 \\
4.0 \\
5.1 \\
0.8 \\
8.6 \\
4.5 \\
5.1 \\
4.3\end{array}$ & $\begin{array}{l}3.2 \\
4.3 \\
5.2 \\
0.9 \\
6.9 \\
3.0 \\
5.4 \\
5.4\end{array}$ & $\begin{array}{l}3.6 \\
4.3 \\
5.1 \\
1.1 \\
7.0 \\
3.0 \\
5.6 \\
4.5\end{array}$ & $\begin{array}{l}3.4 \\
4.3 \\
5.2 \\
1.1 \\
6.8 \\
2.8 \\
6.9 \\
4.5\end{array}$ \\
\hline $\begin{array}{l}\text { Total expenditure } \\
\text { Interest } \\
\text { Non-interest }\end{array}$ & $\begin{array}{c}33.1 \\
0.6 \\
32.5\end{array}$ & $\begin{array}{c}34.3 \\
0.5 \\
33.8\end{array}$ & $\begin{array}{c}40.6 \\
0.6 \\
40.0\end{array}$ & $\begin{array}{c}39.8 \\
0.8 \\
39.0\end{array}$ & $\begin{array}{c}38.0 \\
0.9 \\
37.2\end{array}$ \\
\hline $\begin{array}{l}\text { Primary balance } \\
\text { Overall balance }\end{array}$ & $\begin{array}{l}7.3 \\
6.8\end{array}$ & $\begin{array}{l}4.8 \\
4.3\end{array}$ & $\begin{array}{l}-5.6 \\
-6.2\end{array}$ & $\begin{array}{l}-4.9 \\
-5.6\end{array}$ & $\begin{array}{l}-2.2 \\
-3.1\end{array}$ \\
\hline $\begin{array}{l}\text { Non-oil primary balance } \\
\text { Non-oil overall balance } \\
\text { Non-oil balance excl. one-off receipts 2/ }\end{array}$ & $\begin{array}{l}-3.3 \\
-3.9 \\
-6.2\end{array}$ & $\begin{array}{l}-7.8 \\
-8.3 \\
-8.3\end{array}$ & $\begin{array}{l}-14.4 \\
-15.0 \\
-15.4\end{array}$ & $\begin{array}{l}-13.8 \\
-14.6 \\
-14.6\end{array}$ & $\begin{array}{l}-10.6 \\
-11.5 \\
-11.5\end{array}$ \\
\hline \multicolumn{6}{|l|}{ Federal government } \\
\hline $\begin{array}{l}\text { Total revenue; of which: } \\
\text { Oil revenue } \\
\text { Nonoil revenue }\end{array}$ & $\begin{array}{c}23.4 \\
9.2 \\
14.2\end{array}$ & $\begin{array}{l}22.4 \\
11.1 \\
11.3\end{array}$ & $\begin{array}{c}18.8 \\
7.8 \\
11.0\end{array}$ & $\begin{array}{l}17.1 \\
8.0 \\
9.2\end{array}$ & $\begin{array}{l}16.8 \\
7.6 \\
9.2\end{array}$ \\
\hline $\begin{array}{l}\text { VAT } \\
\text { Excises } \\
\text { Corporate profit tax } \\
\text { Custom tariffs } \\
\text { Other revenue }\end{array}$ & $\begin{array}{l}6.8 \\
0.4 \\
1.9 \\
7.2 \\
7.0\end{array}$ & $\begin{array}{l}5.1 \\
0.4 \\
1.8 \\
8.6 \\
6.4\end{array}$ & $\begin{array}{l}5.2 \\
0.3 \\
0.5 \\
6.9 \\
5.9\end{array}$ & $\begin{array}{l}5.1 \\
0.3 \\
0.4 \\
7.0 \\
4.3\end{array}$ & $\begin{array}{l}5.2 \\
0.3 \\
0.3 \\
6.8 \\
4.2\end{array}$ \\
\hline $\begin{array}{l}\text { Total expenditure } \\
\text { Interest } \\
\text { Non-interest }\end{array}$ & $\begin{array}{c}17.3 \\
0.4 \\
16.8\end{array}$ & $\begin{array}{c}18.8 \\
0.4 \\
18.5\end{array}$ & $\begin{array}{c}24.7 \\
0.5 \\
24.2\end{array}$ & $\begin{array}{c}23.1 \\
0.6 \\
22.4\end{array}$ & $\begin{array}{c}20.1 \\
0.7 \\
19.4\end{array}$ \\
\hline $\begin{array}{l}\text { Primary balance } \\
\text { Overall balance }\end{array}$ & $\begin{array}{l}6.6 \\
6.1\end{array}$ & $\begin{array}{l}3.9 \\
3.5\end{array}$ & $\begin{array}{l}-5.4 \\
-5.9\end{array}$ & $\begin{array}{l}-5.3 \\
-5.9\end{array}$ & $\begin{array}{l}-2.7 \\
-3.4\end{array}$ \\
\hline $\begin{array}{l}\text { Non-oil primary balance } \\
\text { Non-oil overall balance } \\
\text { Non-oil balance excl. one-off receipts } 2 /\end{array}$ & $\begin{array}{l}-2.6 \\
-3.0 \\
-5.3\end{array}$ & $\begin{array}{l}-7.2 \\
-7.6 \\
-7.6\end{array}$ & $\begin{array}{l}-13.2 \\
-13.7 \\
-14.1\end{array}$ & $\begin{array}{l}-13.3 \\
-13.9 \\
-13.9\end{array}$ & $\begin{array}{l}-10.2 \\
-10.9 \\
-10.9\end{array}$ \\
\hline $\begin{array}{l}\text { Financing } \\
\text { Net external } \\
\text { Net domestic } \\
\text { of which: }\end{array}$ & $\begin{array}{l}-6.1 \\
-0.6 \\
-5.5\end{array}$ & $\begin{array}{l}-3.5 \\
-0.4 \\
-3.2\end{array}$ & $\begin{array}{c}5.9 \\
-0.3 \\
6.2\end{array}$ & $\begin{array}{l}5.9 \\
0.2 \\
5.8\end{array}$ & $\begin{array}{l}3.4 \\
0.0 \\
3.4\end{array}$ \\
\hline $\begin{array}{l}\text { Monetary authorities } \\
\text { Other }\end{array}$ & $\begin{array}{c}-5.2 \\
0.0\end{array}$ & $\begin{array}{c}-3.4 \\
0.2\end{array}$ & $\begin{array}{l}5.1 \\
1.1\end{array}$ & $\begin{array}{l}3.9 \\
1.8\end{array}$ & $\begin{array}{l}2.0 \\
1.3\end{array}$ \\
\hline \multicolumn{6}{|l|}{ Memorandum items: } \\
\hline World oil price (U.S.dollars per barrel) & 71.1 & 97.0 & 61.8 & 75.3 & 77.5 \\
\hline \multicolumn{5}{|l|}{ Russian fob oil price balancing the budget: } & 75.3 \\
\hline $\begin{array}{l}\text { General government } \\
\text { Federal government }\end{array}$ & $\begin{array}{l}26.0 \\
23.0\end{array}$ & $\begin{array}{l}52.0 \\
49.0\end{array}$ & $\begin{array}{l}94.5 \\
91.5\end{array}$ & $\begin{array}{l}110.6 \\
107.6\end{array}$ & $\begin{array}{l}97.2 \\
94.2\end{array}$ \\
\hline Oil fund(s) & 11.6 & 16.0 & 11.8 & 6.5 & 3.8 \\
\hline Reserve Fund & 11.6 & 9.7 & 4.7 & 0.6 & 0.0 \\
\hline NWF & 0.0 & 6.2 & 7.1 & 5.9 & 3.8 \\
\hline General government debt & 8.5 & 7.8 & 10.9 & 11.3 & 11.2 \\
\hline GDP (billions of rubles) & 33258 & 41445 & 39064 & 44360 & 49190 \\
\hline
\end{tabular}

Sources: Russian authorities; and IMF staff estimates.

1/ Based on the staff's revenue projections and nominal expenditures in the 2010 budget, inclduing the June supplementary budget.

2/ Excludes a one-off receipt of tax arrears from Yukos in 2007 and one-off transfers from Nanotechnology and Housing Funds in 2009. 
Table 4. Russian Federation: Monetary Accounts, 2007-11 (Billions of rubles, unless otherwise indicated)

\begin{tabular}{|c|c|c|c|c|c|c|c|c|c|c|}
\hline & \multirow{2}{*}{$\frac{2007}{\mathrm{Dec}}$} & \multirow{2}{*}{$\frac{2008}{\mathrm{Dec}}$} & \multicolumn{4}{|c|}{2009} & \multicolumn{3}{|c|}{2010} & \multirow{2}{*}{$\begin{array}{r}2011 \\
\text { Dec }\end{array}$} \\
\hline & & & \multirow[t]{2}{*}{ Mar } & \multirow[t]{2}{*}{ June } & \multirow[t]{2}{*}{ Sept } & \multirow[t]{2}{*}{$\mathrm{Dec}$} & \multirow[t]{2}{*}{ Mar } & \multirow[t]{2}{*}{ Apr. } & \multirow{2}{*}{$\frac{\text { Dec }}{\text { Proj. }}$} & \\
\hline & & & & & & & & & & Proj. \\
\hline \multicolumn{11}{|l|}{ Monetary authorities } \\
\hline Base money & 4,269 & 4,392 & 3,674 & 3,941 & 3,955 & 4,716 & 4,517 & 4,761 & 5,619 & 6,579 \\
\hline Currency issued & 4,119 & 4,372 & 3,658 & 3,908 & 3,869 & 4,623 & 4,411 & 4,644 & 5,489 & 6,424 \\
\hline Required reserves on ruble deposits & 151 & 20 & 16 & 33 & 85 & 93 & 105 & 117 & 130 & 155 \\
\hline NIR 1/ & 11,694 & 11,199 & 10,376 & 11,283 & 11,275 & 12,743 & 13,516 & 14,034 & 14,072 & 15,335 \\
\hline Gross reserves & 11,694 & 12,225 & 11,470 & 11,886 & 11,688 & 13,182 & 13,816 & 14,315 & 14,512 & 15,775 \\
\hline Gross liabilities & 0 & 95 & 1,094 & 437 & 464 & 440 & 301 & 281 & 440 & 440 \\
\hline GIR (billions of U.S. dollars) & 476 & 416 & 390 & 405 & 398 & 436 & 457 & 473 & 480 & 522 \\
\hline NDA & $-7,425$ & $-6,808$ & $-6,702$ & $-7,343$ & $-7,320$ & $-8,027$ & $-8,999$ & $-9,273$ & $-8,453$ & $-8,756$ \\
\hline Net credit to enlarged government & $-5,613$ & $-7,152$ & $-7,265$ & $-6,039$ & $-5,872$ & $-5,515$ & $-5,492$ & $-5,543$ & $-3,777$ & $-2,776$ \\
\hline Net credit to federal government $2 /$ & $-5,085$ & $-6,343$ & $-6,175$ & $-5,151$ & $-4,744$ & $-4,614$ & $-4,297$ & $-4,221$ & $-2,876$ & $-1,874$ \\
\hline CBR net ruble credit to the federal government & $-1,027$ & -615 & -795 & -833 & -996 & -595 & -458 & -607 & -369 & -313 \\
\hline Foreign exchange credit & 118 & 168 & 168 & 184 & 152 & 147 & 142 & 142 & 147 & 147 \\
\hline Ruble counterpart $2 /$ & $-4,176$ & $-5,897$ & $-5,548$ & $-4,502$ & $-3,899$ & $-4,166$ & $-3,981$ & $-3,757$ & $-2,654$ & $-1,708$ \\
\hline CBR net credit to local government and EBFs & -528 & -809 & $-1,090$ & -888 & $-1,128$ & -902 & $-1,194$ & $-1,322$ & -902 & -902 \\
\hline CBR net credit to local government & -324 & -397 & -576 & -544 & -675 & -385 & -614 & -743 & -385 & -385 \\
\hline CBR net credit to extrabudgetary funds & -204 & -412 & -514 & -344 & -453 & -517 & -580 & -579 & -517 & -517 \\
\hline Net credit to banks & $-1,124$ & 2,515 & 2,894 & 1,184 & 1,025 & -53 & -877 & $-1,097$ & $-2,168$ & $-3,430$ \\
\hline Gross credit to banks & 49 & 3,692 & 3,501 & 2,181 & 1,805 & 1,640 & 902 & 861 & 500 & 0 \\
\hline Gross liabilities to banks and deposits & $-1,173$ & $-1,177$ & -606 & -996 & -780 & $-1,693$ & $-1,779$ & $-1,958$ & $-2,668$ & $-3,430$ \\
\hline Of which: correspondent account balances & -802 & $-1,028$ & -431 & -470 & -545 & -900 & -579 & -554 & -792 & -864 \\
\hline Other items (net) $3 /$ & -688 & $-2,170$ & $-2,332$ & $-2,488$ & $-2,473$ & $-2,458$ & $-2,631$ & $-2,633$ & $-2,507$ & $-2,550$ \\
\hline \multicolumn{11}{|l|}{ Monetary survey } \\
\hline Broad money & 14,638 & 16,775 & 15,737 & 16,818 & 17,432 & 19,521 & 19,676 & 20,135 & 24,482 & 29,069 \\
\hline Ruble broad money & 13,272 & 13,493 & 12,112 & 13,161 & 13,650 & 15,698 & 15,997 & 16,435 & 19,914 & 23,622 \\
\hline Currency in circulation & 3,702 & 3,795 & 3,278 & 3,523 & 3,486 & 4,038 & 3,986 & 4,181 & 5,043 & 5,892 \\
\hline Ruble deposits & 9,570 & 9,698 & 8,833 & 9,639 & 10,164 & 11,660 & 12,010 & 12,254 & 14,871 & 17,730 \\
\hline Forex deposits $1 /$ & 1,366 & 3,281 & 3,625 & 3,657 & 3,783 & 3,823 & 3,680 & 3,700 & 4,568 & 5,447 \\
\hline Net foreign as & 9,919 & 10,717 & 10,174 & 11,427 & 12,364 & 13,701 & 14,374 & 14,780 & 14,958 & 16,139 \\
\hline NIR of monetary authorities & 11,694 & 11,199 & 10,376 & 11,283 & 11,275 & 12,743 & 13,516 & 14,034 & 14,072 & 15,335 \\
\hline NFA of commercial banks & $-1,774$ & -482 & -203 & 143 & 1,089 & 959 & 858 & 746 & 886 & 804 \\
\hline NFA of commercial banks (billions of U.S. dollars) & -72 & -16 & -7 & 5 & 37 & 32 & 28 & 25 & 29 & 27 \\
\hline NDA & 4,719 & 6,057 & 5,563 & 5,391 & 5,069 & 5,819 & 5,303 & 5,355 & 9,524 & 12,930 \\
\hline Domestic credit & 7,917 & 11,438 & 10,741 & 11,656 & 12,272 & 13,271 & 13,194 & 13,337 & 17,745 & 21,748 \\
\hline Net credit to general government & $-5,055$ & $-6,436$ & $-7,024$ & $-6,157$ & $-5,822$ & $-4,897$ & $-4,984$ & $-5,153$ & $-2,476$ & -972 \\
\hline Credit to the economy & 12,973 & 17,874 & 17,764 & 17,813 & 18,094 & 18,168 & 18,178 & 18,489 & 20,221 & 22,720 \\
\hline Other items (net) & $-3,199$ & $-5,380$ & $-5,177$ & $-6,265$ & $-7,203$ & $-7,452$ & $-7,892$ & $-7,982$ & $-8,221$ & $-8,818$ \\
\hline \multicolumn{11}{|l|}{ Memorandum items: } \\
\hline Accounting exchange rate (ruble per U.S. dollar, eop) & 24.5 & 29.4 & 29.4 & 29.4 & 29.4 & 30.2 & 30.2 & 30.2 & 30.2 & 30.2 \\
\hline Nominal GDP (billions of rubles) & 32,987 & 41,789 & $\ldots$ & $\ldots$ & $\ldots$ & 39,064 & $\ldots$ & $\ldots$ & 44,360 & 49,190 \\
\hline CPI inflation (12-month change, eop) & 11.9 & 13.3 & 14.0 & 11.9 & 10.7 & 8.8 & 6.5 & 6.0 & 6.0 & 5.4 \\
\hline Ruble broad money velocity & 2.9 & 3.3 & 2.8 & 2.8 & 3.1 & 2.8 & 2.4 & 2.6 & 2.5 & 2.3 \\
\hline Ruble broad money velocity (s.a.) & 3.0 & 3.3 & 3.1 & 3.0 & 2.9 & 2.8 & 2.6 & 2.5 & 2.5 & 2.3 \\
\hline Annual change in velocity & -11.4 & 12.3 & 4.2 & -2.1 & -4.5 & -15.3 & -14.9 & -10.2 & -10.5 & -6.5 \\
\hline Real ruble broad money (rel. to $\mathrm{CPI}, 12$-month chang $\epsilon$ & 31.8 & -10.3 & -20.6 & -17.4 & -14.2 & 6.9 & 24.6 & 26.4 & 19.7 & 12.5 \\
\hline Nominal ruble broad money (12-month change) & 47.5 & 1.7 & -9.5 & -7.6 & -5.0 & 16.3 & 32.1 & 33.2 & 26.9 & 18.6 \\
\hline Base money (12-month change) & 33.1 & 2.9 & -8.6 & -8.8 & -9.8 & 7.4 & 22.9 & 24.6 & 19.1 & 17.1 \\
\hline Real credit to the economy (12-month change) & 33.4 & 21.6 & 9.4 & 1.1 & -2.4 & -6.6 & -3.5 & -1.7 & 5.0 & 6.6 \\
\hline Ruble broad money multiplier & 3.1 & 3.1 & 3.3 & 3.3 & 3.5 & 3.3 & 3.5 & 3.5 & 3.5 & 3.6 \\
\hline
\end{tabular}

Sources: Russian authorities; and IMF staff estimates.

$1 /$ Data calculated at accounting exchange rates.

2/ Represents the government's use of NIR resources and calculated in flow ruble terms.

3 / Inclusive of valuation gains and losses on holdings of government securities. 
Table 5. Russian Federation: Medium-Term Framework and Balance of Payments, 2008-15 (Percent of GDP, unless otherwise noted)

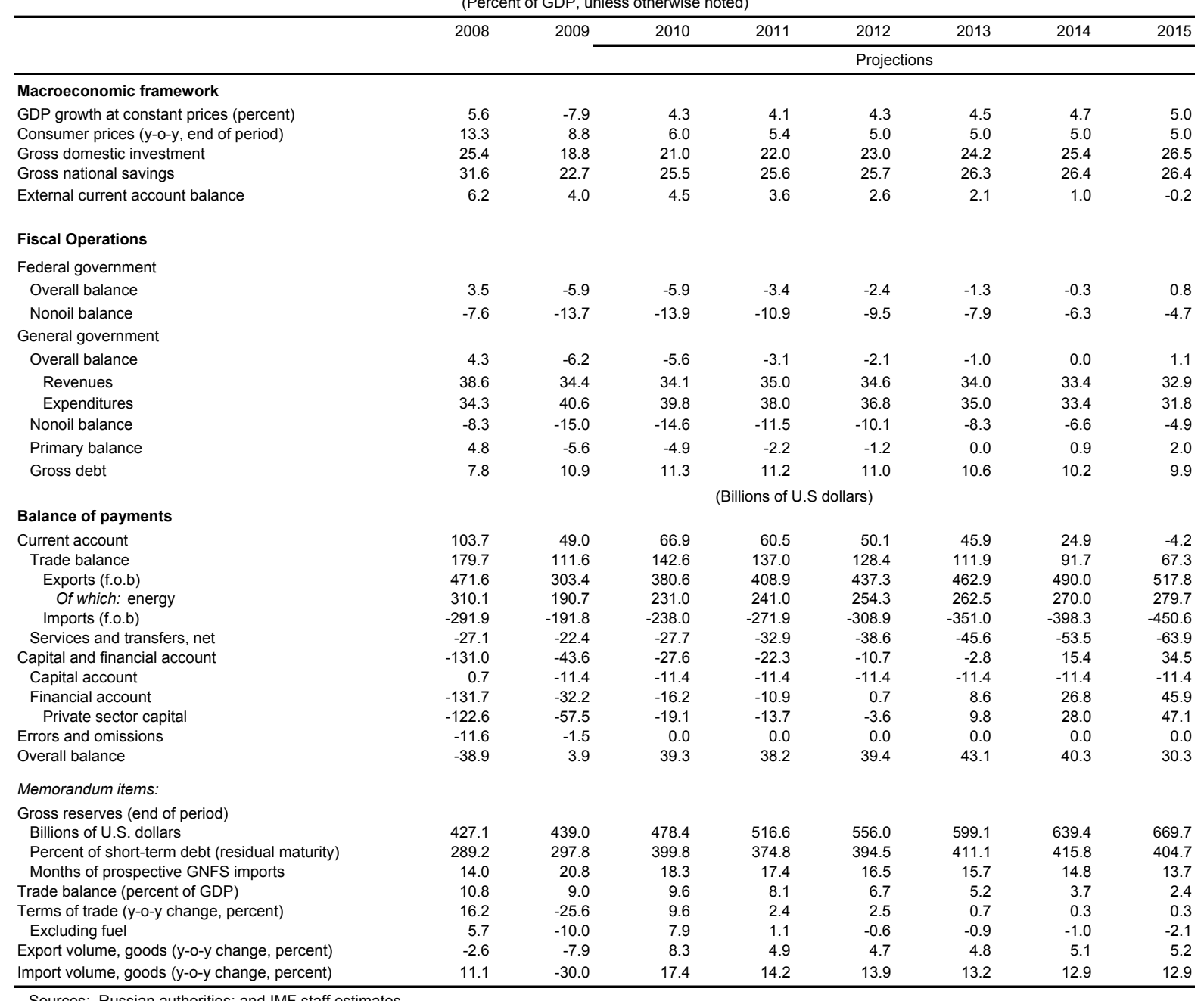

Sources: Russian authorities; and IMF staff estimates. 
Table 6. Russian Federation: Low Growth Scenario Under Unchanged Policies, 2008-15 (Percent of GDP, unless otherwise noted)

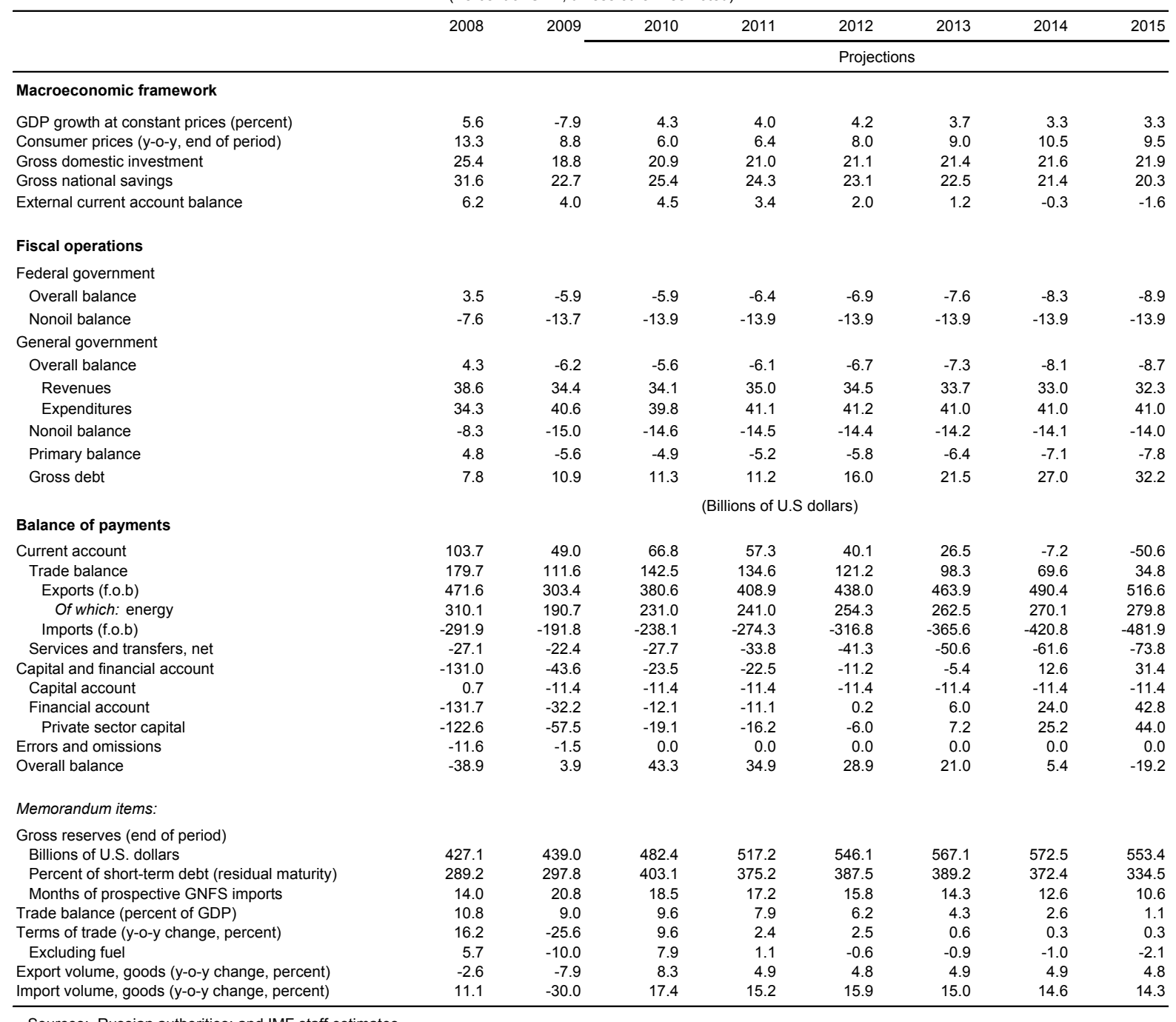

Sources: Russian authorities; and IMF staff estimates. 
Table 7. Russian Federation: Financial Soundness Indicators, 2002-10 1/

\begin{tabular}{|c|c|c|c|c|c|c|c|c|c|}
\hline & 2002 & 2003 & 2004 & 2005 & 2006 & 2007 & 2008 & 2009 & $20102 /$ \\
\hline \multicolumn{10}{|l|}{ Capital } \\
\hline Regulatory capital to risk-weighted assets & 19.1 & 19.1 & 17.0 & 16.0 & 14.9 & 15.5 & 16.8 & 20.9 & 20.5 \\
\hline Regulatory capital to risk-weighted assets (Top 30) & 19.7 & 16.8 & 15.9 & 15.1 & $\ldots$ & $\ldots$ & $\ldots$ & $\ldots$ & $\ldots$ \\
\hline \multicolumn{10}{|l|}{ Asset quality } \\
\hline Nonperforming loans to total gross loans & 5.6 & 5.0 & 3.3 & 2.6 & 2.4 & 2.5 & 3.8 & 9.6 & 9.6 \\
\hline \multicolumn{10}{|l|}{ Sectoral exposures } \\
\hline \multicolumn{10}{|l|}{ Sectoral distribution of loans to total loans } \\
\hline Industry & 36.7 & 33.3 & 28.0 & 22.1 & 20.5 & 18.3 & 19.6 & 22.0 & 22.2 \\
\hline Manufacturing & $\ldots$ & $\ldots$ & $\ldots$ & 16.3 & 14.6 & 13.5 & 14.4 & 15.7 & 16.0 \\
\hline Extraction & $\ldots$ & $\ldots$ & $\ldots$ & 3.5 & 3.9 & 3.1 & 3.3 & 3.9 & 3.8 \\
\hline Utilities & $\ldots$ & $\ldots$ & $\ldots$ & 2.3 & 2.0 & 1.7 & 1.9 & 2.4 & 2.4 \\
\hline Agriculture & 2.2 & 2.4 & 2.7 & 3.0 & 3.6 & 3.8 & 4.2 & 4.9 & 5.1 \\
\hline Construction & 4.4 & 4.4 & 4.5 & 4.6 & 4.9 & 6.0 & 6.1 & 6.2 & 6.5 \\
\hline Trade and restaurants & 21.6 & 20.6 & 18.8 & 23.9 & 19.6 & 18.0 & 17.4 & 18.4 & 18.0 \\
\hline Transport and communication & 4.6 & 5.1 & 4.8 & 4.0 & 3.7 & 3.7 & 4.3 & 3.4 & 3.5 \\
\hline Others & 22.4 & 22.7 & 24.9 & 22.8 & 21.3 & 23.3 & 23.3 & 21.9 & 21.7 \\
\hline Individuals & 8.0 & 11.5 & 16.2 & 19.6 & 23.9 & 24.8 & 25.1 & 23.0 & 22.9 \\
\hline Including house mortgages & $\ldots$ & $\ldots$ & 0.5 & 1.0 & 3.0 & 5.1 & 6.6 & 6.5 & 6.6 \\
\hline \multicolumn{10}{|l|}{ Geographical distribution of interbank loans and deposits } \\
\hline Russia & 41.1 & 54.2 & 54.0 & 47.4 & 35.9 & 40.0 & 27.1 & 29.5 & 32.0 \\
\hline U.K. & 23.4 & 9.0 & 6.6 & 13.0 & 21.5 & 23.3 & 29.1 & 21.7 & 21.1 \\
\hline U.S. & 6.2 & 8.2 & 6.7 & 9.0 & 7.7 & 4.1 & 7.1 & 4.1 & 2.9 \\
\hline Germany & 5.9 & 2.4 & 7.2 & 9.5 & 7.9 & 6.8 & 7.5 & 4.7 & 5.5 \\
\hline Austria & 5.7 & 6.8 & 6.1 & 5.2 & 7.0 & 6.1 & 5.7 & 8.2 & 9.4 \\
\hline France & 1.5 & 1.6 & 3.1 & 3.0 & 3.8 & 3.5 & 4.0 & 5.7 & 3.9 \\
\hline Italy & 1.6 & 1.0 & 1.8 & 1.2 & 1.2 & 1.7 & 1.5 & 1.8 & 2.1 \\
\hline Others & 14.5 & 16.8 & 14.5 & 11.7 & 15.0 & 14.4 & 18.0 & 24.2 & 23.1 \\
\hline \multicolumn{10}{|l|}{ Profitability } \\
\hline Return on assets & 2.6 & 2.6 & 2.9 & 3.2 & 3.3 & 3.0 & 1.8 & 0.7 & 0.9 \\
\hline Return on equity & 18.0 & 17.8 & 20.3 & 24.2 & 26.3 & 22.7 & 13.3 & 4.9 & 6.0 \\
\hline \multicolumn{10}{|l|}{ Liquidity } \\
\hline Liquid assets to total assets & 39.1 & 36.1 & 30.4 & 27.4 & 26.8 & 24.8 & 25.9 & 28.0 & 29.2 \\
\hline Liquid assets to short-term liabilities & 90.6 & 90.4 & 78.0 & 73.7 & 76.8 & 72.9 & 92.1 & 102.4 & 109.9 \\
\hline \multicolumn{10}{|l|}{ Market risk } \\
\hline Net open position in foreign exchange to capital & 18.5 & 8.4 & 5.8 & 5.8 & 5.3 & 3.6 & 3.4 & 3.5 & 3.4 \\
\hline \multicolumn{10}{|l|}{ Other FSIs } \\
\hline Loan loss reserves to total gross loans & 6.3 & 5.9 & 4.9 & 4.6 & 4.1 & 3.6 & 4.5 & 9.1 & 9.5 \\
\hline Interest rate risk to capital & 6.9 & 9.9 & 13.3 & 13.3 & 19.3 & 24.3 & 16.4 & 37.5 & 42.2 \\
\hline Net open position in equities to capital & 11.7 & 12.4 & 12.6 & 14.4 & 20.4 & 10.8 & 3.4 & 8.7 & 8.5 \\
\hline Individual deposits to total liabilities & 24.8 & 27.2 & 27.9 & 28.5 & 27.3 & 25.6 & 21.1 & 25.4 & 26.6 \\
\hline Assets to GDP & 38.3 & 42.1 & 41.7 & 44.8 & 51.9 & 60.8 & 67.3 & 75.4 & \\
\hline Regulatory capital to assets & 14.0 & 14.6 & 13.3 & 12.8 & 12.1 & 13.3 & 13.6 & 15.7 & 15.7 \\
\hline
\end{tabular}

Source: Central Bank of Russia

$1 /$ Credit and depository institutions

2/ As of March, 2010 
Table 8. Russian Federation: Indicators of External Vulnerability, 2005-09

(Percent of GDP, unless otherwise indicated)

\begin{tabular}{|c|c|c|c|c|c|}
\hline & 2005 & 2006 & 2007 & 2008 & 2009 \\
\hline \multicolumn{6}{|l|}{ Financial indicators } \\
\hline Public sector debt $1 /$ & 14.2 & 9.1 & 8.5 & 7.8 & 10.9 \\
\hline Broad money (12-month basis, percent change) & 38.6 & 48.8 & 47.5 & 1.7 & 16.3 \\
\hline Private sector credit (12-month basis, percent change) & 34.2 & 48.5 & 48.5 & 37.8 & 1.6 \\
\hline InterBank Prime Rate (3-month average, percent) & 4.8 & 5.1 & 5.9 & 9.7 & 14.1 \\
\hline InterBank Prime Rate (3-month average, percent, real) & -7.9 & -4.6 & -3.2 & -4.4 & 2.4 \\
\hline \multicolumn{6}{|l|}{ External Indicators } \\
\hline Exports (percent change, U.S. dollars) & 33.1 & 24.5 & 16.8 & 33.1 & -35.7 \\
\hline Imports (percent change, U.S. dollars) & 28.8 & 31.0 & 36.0 & 30.6 & -34.3 \\
\hline Terms of trade (percent change, 12 month basis) & 16.7 & 11.4 & 2.8 & 16.2 & -25.4 \\
\hline Current account balance (billions of U.S. dollars) & 84.4 & 94.3 & 77.0 & 103.7 & 49.0 \\
\hline Capital and financial account balance (billions of U.S. dollars) & -12.5 & 4.6 & 85.7 & -131.0 & -43.6 \\
\hline Inward portfolio investment (debt securities etc.) & -0.8 & 9.5 & 16.9 & -27.4 & 8.2 \\
\hline Other investment (loans, trade credits etc.) & 1.1 & -5.0 & 79.1 & -104.3 & -40.4 \\
\hline Gross official reserves (billions of U.S. dollars) & 182.2 & 303.7 & 478.8 & 427.1 & 439.0 \\
\hline Short-term foreign assets of the financial sector (billions of U.S. dollars) $2 /$ & 20.9 & 33.4 & 42.7 & $\ldots$ & $\ldots$ \\
\hline Short-term foreign liabilities of the financial sector (billions of U.S. dollars) 2/ & 9.8 & 20.7 & 30.5 & $\ldots$ & $\ldots$ \\
\hline Foreign currency exposure of the financial sector (billions of U.S. dollars) 2/ & 1.9 & -12.1 & -18.9 & $\ldots$ & $\ldots$ \\
\hline Official reserves (in months of imports goods and services) & 13.3 & 17.4 & 20.3 & 14.0 & 20.8 \\
\hline Ruble broad money to gross reserves & 1.2 & 1.1 & 1.1 & 1.3 & 1.1 \\
\hline Total short-term external debt to reserves & 81.4 & 71.2 & 30.8 & 18.7 & 18.6 \\
\hline Total external debt (billions of U.S. dollars) & 257.2 & 313.2 & 471.0 & 480.5 & 471.6 \\
\hline Of which: public sector debt (billions of U.S. dollars) & 82.1 & 48.6 & 46.4 & 32.8 & 45.9 \\
\hline Total external debt to exports of goods and services (percent) & 95.7 & 93.6 & 119.6 & 91.9 & 136.7 \\
\hline External interest payments to exports of goods and services & 4.6 & 4.8 & 5.5 & 5.0 & 6.4 \\
\hline External amortization payments to exports of goods and services & 21.7 & 23.2 & 22.8 & 24.5 & 24.4 \\
\hline Exchange rate (per U. S. dollar, period average) & 28.3 & 27.2 & 25.6 & 24.9 & 31.7 \\
\hline REER depreciation (-) (12-month basis) & 9.1 & 9.6 & 5.6 & 6.6 & -6.6 \\
\hline \multicolumn{6}{|l|}{ Financial Market Indicators } \\
\hline Stock market index $3 /$ & 1125.6 & 1921.92 & 2290.51 & 631.9 & 1444.61 \\
\hline Foreign currency debt rating 4/ & BBB & $\mathrm{BBB}+$ & $\mathrm{BBB}+$ & BBB & BBB \\
\hline Spread of benchmark bonds (basis points, end of period) 5 / & 118 & 99 & 157 & 805 & 203 \\
\hline
\end{tabular}

Sources: Russian authorities; and IMF staff estimates.

$1 /$ Gross debt of the general government.

2/ Series discontinued in 2008.

$3 /$ RTS index, end of period.

4/ S\&P long-term foreign currency debt rating, end of period.

5/ JPMorgan EMBIG Russia Sovereign Spread. 
Table 9. Russian Federation: Public Sector Debt Sustainability Framework, 2007-15

(Percent of GDP, unless otherwise indicated)

\begin{tabular}{|c|c|c|c|c|c|c|c|c|c|c|c|c|}
\hline & \multicolumn{2}{|c|}{ Actual } & \multicolumn{3}{|l|}{ Est. } & \multicolumn{6}{|c|}{ Projection } & \multirow{2}{*}{$\begin{array}{c}\text { Debt-stabilizing } \\
\text { primary } \\
\text { balance }\end{array}$} \\
\hline & 2007 & 2008 & 2009 & & & 2010 & 2011 & 2012 & 2013 & 2014 & 2015 & \\
\hline Baseline: public sector debt 1/ & 8.5 & 7.8 & 10.9 & & & 11.3 & 11.2 & 11.0 & 10.6 & 10.2 & 9.9 & -0.1 \\
\hline Of which: foreign-currency denominated & 3.5 & 2.4 & 3.7 & & & 3.3 & 3.1 & 3.0 & 2.6 & 2.2 & 1.9 & \\
\hline Change in public sector debt & -0.5 & -0.7 & 3.0 & & & 0.4 & -0.1 & -0.2 & -0.4 & -0.4 & -0.3 & \\
\hline Identified debt-creating flows & -3.1 & -1.0 & 0.0 & & & 1.6 & -0.2 & -0.3 & -0.5 & -0.5 & -0.4 & \\
\hline Primary deficit (excluding deposits in oil funds from revenue) & -1.6 & -0.4 & -1.2 & & & 1.0 & 0.2 & 0.0 & -0.4 & -0.3 & -0.3 & \\
\hline Revenue (excluding deposits in oil funds) & 34.1 & 34.3 & 41.2 & & & 38.0 & 37.0 & 35.9 & 34.4 & 32.8 & 31.2 & \\
\hline Primary (noninterest) expenditure & 32.5 & 33.8 & 40.0 & & & 39.0 & 37.2 & 35.9 & 34.1 & 32.5 & 30.9 & \\
\hline Automatic debt dynamics $2 /$ & -1.4 & -0.6 & 1.2 & & & -0.6 & -0.3 & -0.2 & -0.1 & -0.1 & -0.1 & \\
\hline Contribution from interest rate/growth differential $3 /$ & -1.2 & -1.2 & 1.1 & & & -0.5 & -0.3 & -0.2 & -0.1 & -0.1 & -0.1 & \\
\hline Of which: contribution from real interest rate & -0.6 & -0.8 & 0.4 & & & -0.1 & 0.2 & 0.3 & 0.4 & 0.4 & 0.4 & \\
\hline Of which: contribution from real GDP growth & -0.6 & -0.4 & 0.7 & & & -0.4 & -0.4 & -0.4 & -0.5 & -0.5 & -0.5 & \\
\hline Contribution from exchange rate depreciation $4 /$ & -0.3 & 0.6 & 0.1 & & & -0.1 & -0.1 & -0.1 & -0.1 & -0.1 & -0.1 & \\
\hline Other identified debt-creating flows & 0.0 & 0.0 & 0.0 & & & 1.3 & 0.0 & 0.0 & 0.0 & 0.0 & 0.0 & \\
\hline Residual, including asset changes 5/ & 2.5 & 0.4 & 3.1 & & & -1.2 & 0.1 & 0.1 & 0.1 & 0.1 & 0.1 & \\
\hline Public sector debt-to-revenue ratio $1 /$ & 24.9 & 22.9 & 26.5 & & & 29.8 & 30.3 & 30.7 & 30.8 & 31.1 & 31.6 & \\
\hline Gross financing need 6/ & -6.1 & -3.7 & 7.0 & & & 6.0 & 3.4 & 2.4 & 1.3 & 0.3 & -0.9 & \\
\hline Billions of U.S. dollars & -79.1 & -61.6 & 86.6 & $10-$ Year & $\overline{10-Y e a r}$ & 89.2 & 56.9 & 46.8 & 27.6 & 6.6 & -23.9 & \\
\hline \multicolumn{13}{|l|}{ Stress tests for public sector debt } \\
\hline Scenario with key variables at their historical averages $7 /$ & & & & & & 8.9 & 7.0 & 5.3 & 3.8 & 2.4 & 1.0 & -0.4 \\
\hline Scenario with no policy change (constant primary balance) in 2009-15 & & & & & & 10.2 & 8.8 & 7.5 & 6.3 & 5.1 & 3.4 & -0.2 \\
\hline Key macroeconomic and fiscal assumptions underlying baseline & & & & Average & Deviation & & & & & & & \\
\hline Real GDP growth (percent) & 8.1 & 5.6 & -7.9 & 5.4 & 4.9 & 4.3 & 4.1 & 4.3 & 4.5 & 4.7 & 5.0 & \\
\hline Average nominal interest rate on public debt (percent) $8 /$ & 7.8 & 7.5 & 7.3 & 6.2 & 1.0 & 8.1 & 8.4 & 8.7 & 9.3 & 9.7 & 9.8 & \\
\hline Nominal appreciation (increase in U.S. dollar value of local currency, percent) & 7.3 & -16.5 & $\ldots$ & -3.1 & 11.6 & $\ldots$ & $\ldots$ & $\ldots$ & $\ldots$ & $\ldots$ & $\ldots$ & \\
\hline Inflation rate (GDP deflator, percent) & 14.4 & 18.0 & 2.3 & 17.3 & 8.7 & 8.9 & 6.6 & 5.7 & 5.1 & 5.2 & 5.2 & \\
\hline Growth of real primary spending (deflated by GDP deflator, percent) & 15.5 & 9.8 & 8.8 & 6.9 & 8.7 & 1.7 & -0.7 & 0.6 & -0.8 & -0.2 & -0.2 & \\
\hline Primary deficit & -1.6 & -0.4 & -1.2 & -3.4 & 2.4 & 1.0 & 0.2 & 0.0 & -0.4 & -0.3 & -0.3 & \\
\hline
\end{tabular}

$1 /$ General government and government-guaranteed gross debt.

2/ Derived as $[(r-p(1+g)-g+a e(1+r)] /(1+g+p+g p))$ times previous period debt ratio, with $r=$ interest rate; $p=$ growth rate of GDP deflator; $g=$ real GDP growth rate; $a=$ share of foreign-currency denominated debt; and $\mathrm{e}=$ nominal exchange rate depreciation (measured by increase in local currency value of U.S. dollar).

3 / The real interest rate contribution is derived from the denominator in footnote $2 /$ as $r-\pi(1+g)$ and the real growth contribution as $-g$.

$4 /$ The exchange rate contribution is derived from the numerator in footnote $2 /$ as ae $(1+r)$.

$5 /$ For projections, this line includes exchange rate changes.

6/ Defined as public sector deficit, plus amortization of medium and long-term public sector debt, plus short-term debt at end of previous period.

7/ The key variables include real GDP growth; real interest rate; and primary balance in percent of GDP.

$8 /$ Derived as nominal interest expenditure divided by previous period debt stock. 
Table 10. Russian Federation: External Debt Sustainability Framework, 2007-2015

(In percent of GDP, unless otherwise indicated)

\begin{tabular}{|c|c|c|c|c|c|c|c|c|c|c|c|c|}
\hline & \multicolumn{3}{|c|}{ Actual } & & & \multicolumn{7}{|c|}{ Projections } \\
\hline & 2007 & 2008 & 2009 & & & 2010 & 2011 & 2012 & 2013 & 2014 & 2015 & Debt-stabilizing \\
\hline Baseline: External debt & 36.2 & 28.8 & 38.3 & & & 31.9 & 28.6 & 26.2 & 24.1 & 22.5 & 21.5 & -1.4 \\
\hline Change in external debt & 4.6 & -7.4 & 9.5 & & & -6.4 & -3.3 & -2.4 & -2.1 & -1.6 & -1.0 & \\
\hline Identified external debt-creating flows & -14.9 & -13.9 & 6.2 & & & -5.1 & -4.5 & -3.5 & -3.0 & -1.9 & -0.7 & \\
\hline Current account deficit, excluding interest payments & -7.6 & -7.8 & -5.8 & & & -5.7 & -4.3 & -3.5 & -3.4 & -2.2 & -1.0 & \\
\hline Deficit in balance of goods and services & -8.6 & -9.3 & -7.5 & & & -8.0 & -6.4 & -4.9 & -3.3 & -1.7 & -0.3 & \\
\hline Exports & 30.3 & 31.3 & 28.0 & & & 29.1 & 27.5 & 26.0 & 24.4 & 22.8 & 21.2 & \\
\hline Imports & 21.7 & 22.0 & 20.6 & & & 21.1 & 21.1 & 21.1 & 21.2 & 21.1 & 20.9 & \\
\hline Net non-debt creating capital inflows (negative) & -1.8 & 0.2 & 1.5 & & & 0.7 & 0.2 & 0.2 & 0.1 & 0.1 & 0.1 & \\
\hline Automatic debt dynamics $1 /$ & -5.6 & -6.2 & 10.5 & & & -0.2 & -0.4 & -0.2 & 0.2 & 0.2 & 0.2 & \\
\hline Contribution from nominal interest rate & 1.7 & 1.6 & 1.8 & & & 1.2 & 0.8 & 0.9 & 1.2 & 1.2 & 1.2 & \\
\hline Contribution from real GDP growth & -1.9 & -1.6 & 3.1 & & & -1.4 & -1.1 & -1.1 & -1.0 & -1.0 & -1.0 & \\
\hline Contribution from price and exchange rate changes $2 /$ & -5.3 & -6.2 & 5.6 & & & $\ldots$ & $\ldots$ & $\ldots$ & $\ldots$ & $\ldots$ & $\ldots$ & \\
\hline Residual, incl. change in gross foreign assets $3 /$ & 19.5 & 6.4 & 3.3 & & & -1.3 & 1.2 & 1.0 & 0.9 & 0.3 & -0.3 & \\
\hline External debt-to-exports ratio (in percent) & 119.6 & 91.9 & 136.7 & & & 109.8 & 103.8 & 100.5 & 98.6 & 98.6 & 101.2 & \\
\hline Gross external financing need (in billions of US dollars) $4 /$ & 72.1 & 112.4 & 98.7 & & & 80.5 & 59.1 & 87.7 & 95.0 & 120.8 & 158.0 & \\
\hline in percent of GDP & 5.5 & 6.7 & 8.0 & $\overline{10-Y e a r}$ & 10-Year & 5.4 & 3.5 & 4.6 & 4.4 & 4.9 & 5.6 & \\
\hline Scenario with key variables at their historical averages 5 / & & & & & & 31.9 & 20.1 & 9.1 & -1.1 & -10.7 & -19.7 & 2.5 \\
\hline Key Macroeconomic Assumptions Underlying Baseline & & & & $\begin{array}{c}\text { Historical } \\
\text { Average }\end{array}$ & $\begin{array}{l}\text { Standard } \\
\text { Deviation }\end{array}$ & & & & & & & \\
\hline Real GDP growth (in percent) & 8.1 & 5.6 & -7.9 & 5.4 & 4.9 & 4.3 & 4.1 & 4.3 & 4.5 & 4.7 & 5.0 & \\
\hline GDP deflator in US dollars (change in percent) & 21.6 & 21.5 & -19.9 & 15.0 & 13.5 & 15.9 & 9.1 & 8.7 & 8.2 & 8.4 & 8.4 & \\
\hline Nominal external interest rate (in percent) & 6.9 & 5.5 & 4.6 & 5.9 & 0.6 & 3.8 & 2.7 & 3.6 & 5.4 & 5.7 & 6.0 & \\
\hline Growth of exports (US dollar terms, in percent) & 17.7 & 32.7 & -34.0 & 17.4 & 21.8 & 25.2 & 7.6 & 7.1 & 6.1 & 6.1 & 5.8 & \\
\hline Growth of imports (US dollar terms, in percent) & 35.1 & 30.0 & -31.0 & 18.7 & 18.6 & 23.7 & 13.9 & 13.3 & 13.3 & 13.1 & 13.0 & \\
\hline Current account balance, excluding interest payments & 7.6 & 7.8 & 5.8 & 11.4 & 4.6 & 5.7 & 4.3 & 3.5 & 3.4 & 2.2 & 1.0 & \\
\hline Net non-debt creating capital inflows & 1.8 & -0.2 & -1.5 & -0.1 & 0.9 & -0.7 & -0.2 & -0.2 & -0.1 & -0.1 & -0.1 & \\
\hline
\end{tabular}

$1 /$ Derived as $[r-g-\rho(1+g)+\varepsilon \alpha(1+r)] /(1+g+\rho+g \rho)$ times previous period debt stock, with $r=$ nominal effective interest rate on external debt; $\rho=$ change in domestic GDP deflator in US dollar terms, $g=$ real GDP growth rate, $\varepsilon=$ nominal appreciation (increase in dollar value of domestic currency), and $\alpha=$ share of domestic-currency denominated debt in total external debt.

$2 /$ The contribution from price and exchange rate changes is defined as $[-\rho(1+g)+\varepsilon \alpha(1+r)] /(1+g+\rho+g \rho)$ times previous period debt stock. $\rho$ increases with an appreciating domestic currency $(\varepsilon>0)$ and rising inflation (based on GDP deflator).

$3 /$ For projection, line includes the impact of price and exchange rate changes.

4/ Defined as current account deficit, plus amortization on medium- and long-term debt, plus short-term debt at end of previous period.

5/ The key variables include real GDP growth; nominal interest rate; dollar deflator growth; and both non-interest current account and non-debt inflows in percent of GDP.

6/ Long-run, constant balance that stabilizes the debt ratio assuming that key variables (real GDP growth, nominal interest rate, dollar deflator growth, and non-debt inflows in percent of GDP) remain at their levels

of the last projection year. 


\section{ANNEX I. RUSSIA's EXPERIENCE WITH CAPITAL FlOWS}

Russia experienced large capital inflows in the run-up to the global financial crisis. Steadily increasing oil prices, combined with a prudent policy of taxing and saving most of the oil revenue, had significantly strengthened Russia's external position. By August 2008, international reserves had increased to almost US\$600 billion and were the third highest in the world. This apparent stellar performance — combined with a very favorable outlook for oil prices - made Russia an attractive destination for foreign capital.

The boom years. Private capital inflows came largely in the form of loans to corporates and commercial banks, with a much smaller portion in the form of portfolio and direct investment. Buoyed by ever increasing oil prices, gross private capital inflows increased from around $\$ 70$ billion in 2005 to $\$ 100$ billion in 2006 to over $\$ 200$ billion in 2007 .

Like many other emerging European economies, Russia experienced a credit boom as foreign capital poured into the country.

- $\quad$ Credit growth averaged nearly 50 percent per year from 2006 until mid-2008, as the banking system - flush with liquidity from capital inflows and deposit growth-lent generously to Russian households and corporates.

- $\quad$ Domestic demand growth reached $13 \frac{1}{2}$ percent in 2007 , driven by booming consumption and investment. With the economy at full capacity, real wages rose by close to 20 percent that year.
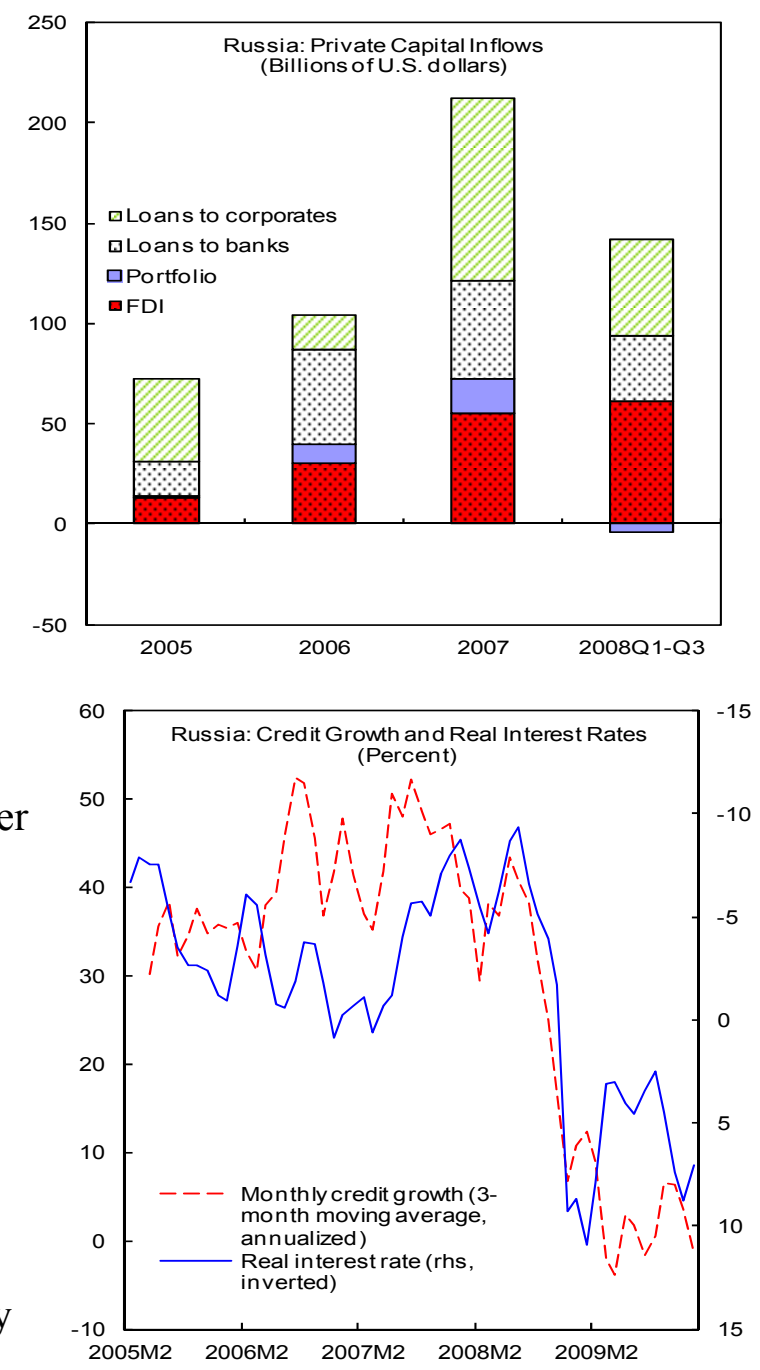

Procyclical macroeconomic policies and structural weaknesses contributed to excessive capital inflows and overheating.

- $\quad$ Fiscal policy was expansionary. The general government nonoil deficit deteriorated from 2.9 percent of GDP in 2004 to 8.3 percent of GDP in 2008. However, the headline balance continued to show large surpluses as a result of surging oil revenues.

- $\quad$ Monetary policy became increasingly geared toward managing the exchange rate. Rising oil prices and capital inflows put pressure on the ruble to appreciate. 
Concerned with the impact of exchange rate appreciation on competitiveness, the central bank intervened to resist these pressures. The resulting policy of controlled and predictable ruble appreciation encouraged one-way currency bets and speculative inflows. As oil prices approached record highs and capital inflows surged, the unsterilized interventions contributed to negative real interest rates and high, entrenched inflation - which reached 15 percent in mid-2008.

- $\quad$ Finally, long-standing weaknesses in banking supervision and regulation allowed rapid credit expansion and the build-up of large unhedged foreign exchange exposures in the run-up to the crisis.

Despite these similarities with the rest of emerging Europe, Russia is distinct in three key areas: (i) the role of oil; (ii) the lower share of foreign ownership; and (iii) the significant borrowing outside the banking system.

- $\quad$ First, as an oil exporter, Russia's capital inflows came on top of very large current account surpluses. This made Russia especially vulnerable to an oil price shock, coupled with a reversal of capital flows.

- $\quad$ Second, nearly all of the foreign borrowing by banks and nonfinancial corporates was in the form of wholesale financing (syndicated loans and bonds) rather than transactions between parent banks and their subsidiaries. This is explained by the 100 relatively low share of foreign ownership in the Russian banking system ( 25 percent) compared with some other emerging

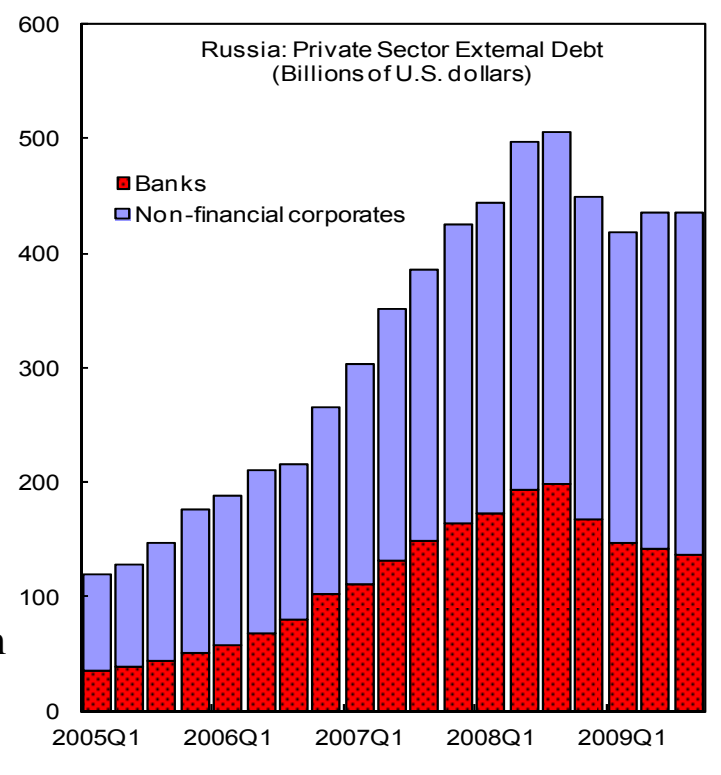
European economies.

- $\quad$ Third, capital did not just flow into Russia through the banking system. In fact, flows to the banking system were relatively low in Russia, compared to other emerging European countries. Direct flows to the corporate sector were much more important in Russia. Large nonfinancial corporates had access to plentiful foreign financing through both the syndicated loan market and the bond market. Low spreads - possibly as a result of excess global liquidity and high sovereign ratings - alongside a heavily managed exchange rate, encouraged corporates to borrow in foreign currency rather than rubles. In addition, implicit government guarantees made it easy for state-owned companies to engage in large-scale quasi-sovereign borrowing. As a result, in Russia, it is the corporate sector-rather than the household sector-that has become heavily indebted. 
The crisis. The crisis hit Russia with particular virulence. The dual shock of collapsing oil prices and a reversal of capital flows put the heavily managed exchange rate under extreme pressure. Given large bank and corporate exposures in foreign currency, the authorities allowed a controlled depreciation of the ruble, while providing significant ruble liquidity. The strategy entailed the loss of one-third - $\$ 200$ billion — of the central bank's reserves. The economy sank into a deep recession. One year later, oil prices are roughly double their trough levels, the economy has begun to grow again, and the ruble is appreciating. And capital is starting to trickle

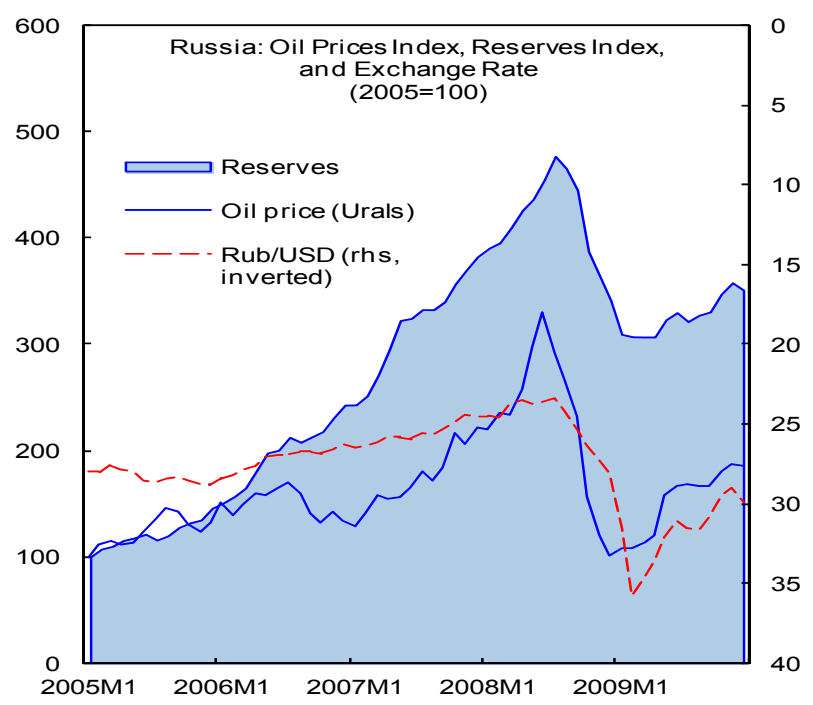
back to Russia.

Policy challenges. Over the past year, greater exchange rate flexibility and low policy interest rates have helped keep speculative private capital inflows to Russia in check. In the current circumstances of moderately rising oil prices, these measures should be sufficient to allow Russia to manage its capital inflows.

- $\quad$ The first line of defense against renewed capital inflows should be an appropriate macroeconomic policy mix geared to containing domestic demand once the economy recovers. Fiscal policy should be the main tool for mitigating pressures on the real exchange rate in the face of rising oil prices - it will need to be sufficiently countercyclical to do so. Monetary policy should be squarely aimed at keeping inflation low in the context of a flexible exchange rate. Greater exchange rate flexibility (and, by extension, volatility) should help to discourage speculative inflows.

- $\quad$ Complementary policies will also be needed. Prudential regulations should be shored up to limit the risks of credit booms. This could include counter-cyclical regulatory requirements, restrictions on foreign currency lending, and differentiated reserve requirements to reduce currency and maturity risks. Improved supervision will also be key - this implies the need for greater powers for the central bank to supervise not only banks, but also their affiliates. The Russian authorities are considering a number of these measures.

In an environment of surging capital inflows, standard macroeconomic and prudential tools may not be sufficient or appropriate. For example, an excessive appreciation of the exchange rate could damage competitiveness. Reserve accumulation can be costly, and - if not sufficiently sterilized - can stoke inflation. And a strong fiscal position, particularly if 
accompanied by low public debt and robust international reserves, can perversely end up attracting even greater inflows.

In such an environment, capital controls may be a legitimate component of a broader package of policies responding to surges in capital inflows. However, controls are not a panaceathey can be difficult to enforce (especially outside the banking system), they can be circumvented, and their effectiveness is unclear. Moreover, they cannot serve as a substitute for reforms that allow the economy to respond more flexibly to the macroeconomic impacts of sustained capital inflows. 


\section{INTERNATIONAL MONETARY FUND \\ RUSSIAN FEDERATION}

\section{Staff Report for the 2010 Article IV Consultation-Informational Annex}

Prepared by the European Department

(In consultation with other departments and the World Bank)

June 09,2010

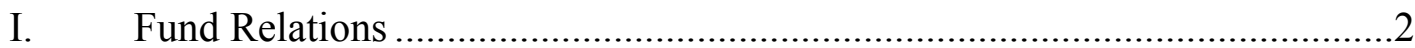

II. Relations with the World Bank Group......................................................

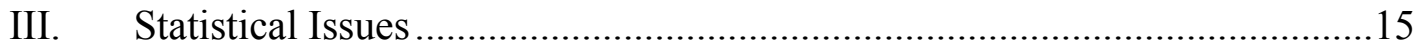




\section{ANNEX I. RUSSIAN FEDERATION: FUND RELATIONS}

(As of May 31, 2010)

I. Membership Status: Joined 06/01/1992; Article VIII.

II. General Resources Account:

Quota

Fund holdings of currency

Reserve position

III. SDR Department:

Net cumulative allocation

Holdings
SDR Million

$5,945.40$

$4,716.1$

1229.36

SDR Million Percent of Allocation

5671.80

5676.32
Percent of Quota

100.00

79.32

20.68

100.00

00.08

IV. Outstanding Purchases and Loans: None

V. Latest Financial Arrangements:

\begin{tabular}{lcccc}
\hline \multicolumn{1}{c}{ Type } & $\begin{array}{c}\text { Approval } \\
\text { Date }\end{array}$ & $\begin{array}{c}\text { Expiration } \\
\text { Date }\end{array}$ & $\begin{array}{c}\text { Amount Approved } \\
\text { (SDR million) }\end{array}$ & $\begin{array}{c}\text { Amount Drawn } \\
\text { (SDR million) }\end{array}$ \\
\hline Stand-by & $07 / 28 / 99$ & $12 / 27 / 00$ & $3,300.00$ & 471.43 \\
EFF & $03 / 26 / 96$ & $03 / 26 / 99$ & $6,305.57$ & $1,443.45$ \\
Of which SRF & $07 / 20 / 98$ & $03 / 26 / 99$ & $3,992.47$ & 675.02 \\
EFF & $03 / 26 / 96$ & $03 / 26 / 99$ & $6,901.00$ & $4,336.26$ \\
\hline
\end{tabular}

VI. Projected Payments to Fund (SDR Million; based on existing use of resources and present holdings of SDRs):

Principal

Forthcoming

$\begin{array}{lllll}2010 & 2011 & 2012 & 2013 & 2014\end{array}$

Charges/Interest

Total

$\begin{array}{llll}0.05 & 0.05 & 0.05 & 0.05 \\ 0.05 & 0.05 & 0.05 & 0.05\end{array}$

VII. Implementation of HIPC Initiative: Not Applicable

VIII. Implementation of MDRI Assistance: Not Applicable

IX. Exchange Arrangements: The de jure arrangement is other managed arrangement - namely, a controlled floating exchange rate arrangement. The ruble value of a bi-currency basket is used as the operating benchmark for transactions on the internal currency market. The basket is currently composed of $€ 0.45$ and $\$ 0.55$. The target boundaries of its permissible fluctuations were revised based on 
changes in fundamental factors governing formation of the country's balance of payments in accordance with the Uniform State Monetary Policy Guidelines for 2008 , in response to a gradual transition to a more flexible exchange-rate-setting policy. Following a period of significant controlled depreciation of the ruble, on January 23 2009, the CBR announced that the upper boundary of permissible fluctuation in the market value of the bi-currency basket would be set at Rub 41 and the lower boundary at Rub 26. The actual value of the bi-currency basket is determined within this band under the influence of both market factors and exchange interventions by the CBR. The CBR intervenes both in interbank currency exchanges and on the over-the-counter interbank market to limit daily fluctuations. The permissible fluctuations may be revised in response to changes in macroeconomic indicators. As a result of these policy changes and the continued control of the $\mathrm{CBR}$ over the exchange rate determination, the de facto exchange rate arrangement is other managed arrangement. The Russian Federation accepted the obligations of Article VIII, Sections 2, 3, and 4 of the IMF Articles of Agreement with effect from June 1, 1996, and maintains an exchange system free of restrictions on the making of payments and transfers for currents international transactions.

X. Article IV Consultation: Russia is on the standard 12-month consultation cycle. The last consultation was concluded on July 27, 2009.

XI. $\quad$ FSAP Participation and ROSCs

Russia participated in the Financial Sector Assessment Program during 2002, and the FSSA report was discussed by the Board in May 2003, at the time of the 2003 Article IV discussion (IMF Country Report No. 03/147). An FSAP update took place in the fall of 2007, and the FSSA report was discussed by the Board in August 2008, at the time of the 2008 Article IV discussion.

A Fiscal Transparency ROSC mission, headed by Peter Heller (FAD), visited Moscow in July 2003, and a new Data ROSC module was undertaken by a mission in October 2003, led by Armida San Jose (STA). A mission led by Ms. San Jose undertook a reassessment of Data ROSC module in July 2010.

\section{Resident Representatives:}

Mr. Odd Per Brekk, Senior Resident Representative, since March 1, 2009. 


\section{ANNEX II. RUSSIAN FEDERATION: RELATIONS WITH THE WORLD BANK GROUP}

World Bank Group activities are guided by the Country Partnership Strategy (CPS) Progress Report endorsed by the Board of Directors on September 8, 2009. It extended the CPS period (2007-2009) to 2011 and reiterated the relevance of four guiding objectives: i) diversify the economy for sustainable development and growth; ii) improve public sector management and performance; iii) improve the delivery of communal and social services; and iv) enhance Russia's global role as a donor.

Relations between the Russian Federation and World Bank Group are evolving in line with socio-economic conditions. Given Russia's strong fiscal position up until the global financial crisis, traditional cooperation activities shifted from financing to knowledge services. The portfolio declined from 22 to 13 projects ( $\$ 1.3$ billion), while fee-based services (21 contracts valued at $\$ 9.5$ million) and sub-national lending through the WBG facility ( 8 loans for $\$ 154$ million to date) emerged as new business lines.

With the emergence of pressure on Russia's fiscal reserves and external position in 2009, Russia initiated discussions on new financing from the World Bank in FY11-12. The Government aims to leverage international knowledge to help modernize the economy, increase the efficiency of public expenditures, deepen the financial sector, and strengthen the position of Russia in the post-crisis period. Given substantial developmental challenges at the sub-national level, the federal government has encouraged the Bank Group to continue its direct involvement with regions. A central theme of the extended CPS will thus be to undertake more in-depth operations in selected regions in line with demand and the partnership strategy.

IFC and MIGA operations are in very high demand and they must carefully manage large exposures (Russia is IFC's third largest and MIGA's largest exposure). The Bank cooperates actively with IFC, not only in subnational lending but also on key development priorities such as energy efficiency and renewable energy.

\section{Major areas of Bank Group activities by CPS strategic pillars}

\section{(a) Diversifying the economy for sustainable development and growth}

1. The World Bank Group is assisting Russia in various ways in meeting the challenges of sustaining rapid growth, including participation in macro-policy debates, monitoring the investment climate, supporting public investment and PPPs for growth and diversification, working with regions to identify and overcome barriers to growth, supporting investments in priority areas at the regional level, and providing direct assistance to the private sector:

- $\quad$ Macroeconomic policy, long-term fiscal sustainability, and the effective management of Russia's large external inflows: The Bank contributes to the macro-policy debate 
in Russia through the periodic Russian Economic Reports, on-demand policy notes and knowledge sharing. In addition, there is strong interest in the Bank's technical assistance in advising on the fiscal and broader economic implications of oil price volatility. The Bank has finished a study on long-term fiscal risks and fiscal sustainability for the Ministry of Finance highlighting alternative fiscal scenarios, associated risks and strategies for achieving long-term fiscal sustainability. In April 2008, the Bank of Russia and World Bank Treasury formally signed a fee-based services agreement whereby Treasury will provide technical support in internal investment management capacity for a period of 3 to 4 years.

- $\quad$ Financial sector strengthening. In addition, the Bank helped strengthen the financial sector through lending and TA for securities market regulation, development of the Government's financial sector strategy, development of new institutional arrangements for management of government assets and liabilities, (including reserves and stabilization funds), insurance and banking sector supervision, assessment of the sustainability of the $2^{\text {nd }}$ pillar pension system, management of the increasing share of nonperforming loans (NPLs) accumulated through the system during the crisis, strengthening of banking supervision, and assessment of their resolution framework (notably insolvency and creditors' rights system). On a fee basis, the Bank provided TA to the Central Bank to support payments system development and monitoring. In addition, the Bank is currently developing two new investment operations with financial sector content - the Financial Literacy and Education Project designed to strengthen financial literacy and enhance protection of financial services' consumers, and the Microfinance Project designed to strengthen financial cooperatives and facilitate their integration into the country's financial system. IFC responded to the crisis-related needs of client banks through a rebalanced product mix, combining short term liquidity (particularly trade finance) and risk management instruments with financial support in the form of guarantees, quasiequity and subordinated debt to strengthen the capital bases of client banks, contribute to the stability of the financial system and mobilize additional private investment into the sector. IFC's Russia Banking Advisory Program worked closely with investment services and the IBRD to develop new crisis response tools to address rising levels of NPLs and assist banks with risk management. IFC's Housing Advisory Program was refocused to help client banks manage exposure to real estate and mortgage markets, and conducted seminars on mortgage portfolio management and analytics for banks and financial regulators. IFC has also committed its first regional investments in factoring and distressed asset management to support corporate restructurings and single asset recovery situations. IFC's longer term priorities in the financial sector include increasing access to finance for SMEs, particularly in the regions, promoting financial sector stability and environmental sustainability, and leveraging IFC capital through mobilization and cooperation with partners. In May 2010, IFC's board approved IFC's investment alongside the 
Government of Russia in the Russia Bank Capitalization Fund (RBCF), which would make equity and/or equity related investments to support private, mainly second-tier banks, with an emphasis on regional banks.

- Investment climate monitoring and policy advice: The Bank continues periodic business environment and enterprise performance (BEEPS) surveys, regional investment climate assessments (through sub-national Doing Business assessments), and administrative barriers studies undertaken by FIAS for interested regions. The Bank can work at the regional level on capacity building and the development of investment promotion programs for attracting FDI, similar to the initiative currently underway in Rostov Region. WBI will continue capacity-building activities related to investment climate assessments.

- $\quad$ Contributing to climate change mitigation. At present, the World Bank is discussing an energy efficiency investment project with the Ministry of Energy, Russian Energy Agency and systemic banks. The project would assist the Ministry and Agency in building capacity on energy efficiency matters and provide funding to energy efficiency credit lines at banks. IFC and the IBRD worked closely with Russian policymakers to calculate the country's energy efficiency potential and subsequently to develop the federal law On Energy Efficiency Improvement and Energy Saving, signed by President Medvedev in December 2009. IFC and IBRD are currently advising the government on secondary legislation and related by-laws and institutions (including at the sub-national level). IFC is currently implementing four integrated advisory and investment projects to develop the market for investment in energy efficiency, renewable energy and cleaner production in Russia. The Russia Sustainable Energy Finance Program provides advisory services and financing to partner banks to promote investment in energy efficiency and renewable energy. IFC's Russia Cleaner Production Program is focused on stimulating investments in cleaner technologies to increase resource efficiency and reduce environmental and social impacts in the real sectors. IFC is cooperating actively with IBRD and EBRD on the Russia Residential Energy Efficiency Program, which aims to stimulate investment in the energy-efficient renovation of multi-family residential buildings. In April 2010, in conjunction with the IBRD, IFC launched the Russia Renewable Energy Program, with a $\$ 10$ million an advisory component funded by the GEF; IFC expects to facilitate at least $\$ 360$ million in renewable energy investment over five years.

- $\quad$ Supporting Government investment and public-private partnerships (PPPS) for growth and diversification: On-going investment projects support land registration and the development of a national cadastre for securing property rights and the development of land markets. The Bank has provided technical assistance on a reimbursable basis to support the development of PPPs, particularly in St. Petersburg for transaction and strategic advice on large-scale infrastructure projects, including 
Western High Speed Diameter, Orlovsky tunnel, and Pulkovo airport. Despite the adverse investment environment caused by the global financial crisis, Pulkovo reached financial close in April 2010, with IFC committing over \$94 million to the overall financing package for its own account. IFC and EBRD are currently arranging an additional \$220 million in syndicated loans. The Bank is cooperating with Russia's Development Bank (VneshEconomBank - VEB) on both PPP joint activities and on developing a partial credit guarantee of the Bank to VEB in support of its efforts to raise funding for infrastructure investments. In addition, the Bank supported efforts of the Higher School of Economics of Moscow to develop an e-learning program on PPPs for federal and regional decision makers in Russia, as well as in other Russianspeaking countries in the region.

- Working with regions to identify engines of growth, develop growth strategies, and remove barriers to growth and labor mobility: The Bank held two major knowledge events on regional development strategies in early 2008: an early discussion of the World Development Report on regional disparities and its implications for Russia, and Regional Development Strategies workshop for Russia's regional governments and other stakeholders of regional development. In addition, the Bank has finalized a Country Economic Memorandum focused on barriers to growth at the sub-national level and on issues of regional agglomerations. The development of fee-for-service arrangements with the regions would provide another avenue for supporting preparation of regional investment strategies and growth analyses, and provision of other analytical services. As part of its anti-crisis work the Bank has intensified policy advice on labor market monitoring and on the design of the active labor market policies, that also support mobility. Also, the Bank is starting new analytical work on internal migration in Russia as part of a broader, CIS-wide engagement on migration issues and policies.

- $\quad$ Supporting investments in priority areas at the regional level: The IFC/Bank SubNational Development Program is supporting priority public investments at the regional and municipal level. To date, eight such sub-national operations have been completed, including three projects in the Chuvash Republic, two projects in the Republic of Mariy El, and projects in Petropavlosk municipality (Kamchatka), the city of Mytischi, and the city of Ufa. IFC and IBRD are working directly with several Russian regions (Oblasts) to develop three to five year regional energy savings programs, using best global practices. MIGA can play a role in supporting foreign direct investment in infrastructure at the sub-sovereign level, including in the transportation, water and solid waste sectors. Regional infrastructure projects supported by the Subnational Program are another area where the Bank and IFC could partner with VEB for joint project preparation and support.

- $\quad$ Providing direct support to the private sector: IFC will continue to promote the growth of the private sector and the diversification of the Russian economy through a 
combination of investment and advisory services. IFC's selective medium to longterm strategy is to: (i) contribute to climate change mitigation and develop the sustainable energy market through financing and provision of advisory services via the Russia Sustainable Energy Finance Program, the Russia Cleaner Production program, the Russia Renewable Energy Program, the Russia Residential Energy Efficiency Program and through direct investments; (ii) invest in Russia's infrastructure, especially transport and logistics (ports, roads, warehousing) and subnational infrastructure (especially in Russia's poorer regions), including through the joint IFC/IBRD Sub-National Development Program; (iii) provide ongoing support to the financial sector, in particular by increasing access to finance for SMEs, promoting financial sector stability and environmental sustainability and through development of the insurance, pension and risk management industries; and, across sectors (iv) invest in Russia's less-developed regions where significant developmental challenges remain, and support projects contributing to Russia's economic diversification, including in value-added manufacturing such as machine building, and in hi-tech sectors. IFC also aims to leverage its own capital through mobilization and cooperation with partners, including through participation in jointly financed facilities to target the banking sector and infrastructure development.

- $\quad$ IFC advisory services will continue to focus on crisis recovery and climate change mitigation: IFC's advisory programs in Russia are closely integrated with investment activities and address the following objectives: (a) improving the energy efficiency of Russia's economy and reducing its greenhouse gas emissions; (b) building the capacity of private banks to deliver new product lines, such as energy efficiency, residential energy efficiency and renewable energy finance; and (c) responding to the crisis-related needs of the banking and real sectors, including risk and NPL/distressed asset management, and managing exposure to real estate and mortgage markets.

- $\quad$ MIGA will continue to support foreign investors through the provision of political risk guarantees: Supporting foreign investment in infrastructure, in close coordination with the Bank, will remain an important area of MIGA's activity in Russia. In the financial sector, the Agency will continue to explore opportunities to support capital markets transactions, including asset-backed securitizations. MIGA may also continue to promote the role and assist in the expansion of foreign banks in the Russian banking sector. Areas for potential further involvement in Russia include manufacturing, agribusiness and services sectors.

\section{(b) Improving public sector management and performance}

2. Public sector management has been a particular area of strength of World Bank work in Russia, which will be further deepened in coming years. The Bank remains engaged in supporting programs for modernizing selected public sector institutions, improving government administration, the judiciary, local self-government, and budgetary management 
at federal and sub-national levels. The Bank will expand its engagement in regions in these areas, in accordance with the federal priority for improving public sector performance at the sub-national level.

- $\quad$ Modernizing selected public sector institutions: The completion of on-going projects will contribute to the modernization of public institutions and improved public services. These include tax modernization, customs development, cadastre and registration, fiscal federalism, performance-based budgeting, treasury development, and a statistical development project.

- $\quad$ Supporting the government program in administrative reform: The Bank will continue its close engagement with the government in the area of administrative reform at the federal and sub-national levels, including the coordination and implementation of substantial donor funds. The primary goal will continue to be bringing Bank and international expertise to bear on the implementation of the government's program for administrative reform, which currently places a strong emphasis on encouraging initiatives at the sub-national level. So far, the Bank has concentrated sub-national work in the Southern Federal Okrug and regions in the North-West. A fee-based advisory service supported Khanti-Mansiysk Okrug-Yugra on administrative streamlining and functional reviews. Similar fee-based advisory services may also be developed with other regions. Support for public administration and governance for selected regions which cannot afford fee-based services is being provided through a DFID Trust Fund which runs from 2007-10.

- $\quad$ Providing analytical support on effectiveness of public expenditures, transparency and accountability. At the request of the Ministry of Finance, the Bank has advanced work on a Public Expenditure Review (PER) focusing on the overall structure and efficiency of public expenditures with particular focus on the wage bill and transportation expenditures. The Bank is also providing advisory assistance to the Ministry of Finance on the development of a strategy for increasing the efficiency of public expenditures. The Bank is advising the Ministry of Economic Development on improvements in public procurement legislation. In close coordination, it is pursuing a Social Expenditures Review (SER) focusing on efficiency in use of public resources in health, education and social assistance, with focus on sub-national level.

- $\quad$ Supporting budgetary reforms: The Bank will continue to respond to the demands of the federal and some regional governments for assistance in budgetary reform and the development of performance-based budgeting. In particular, the Bank is using the Regional Fiscal Technical Assistance Project to provide support to the MOF in its transition towards program budgeting principles, in transformation of budgetary institutions into autonomous entities, and in the reform of the systems of internal control and external audit. 
- $\quad$ Promoting the reform of local self-government: The Bank will continue to bring international experience to bear on this vital area of reform in Russia. A study has been completed for monitoring and assisting the development of local-self government in rural areas in the Perm, Penza, and Adygeya regions. On the operational side the Bank is engaging three regions of Russia on practical expansion of community-based development schemes, providing these regions technical assistance through fee-based arrangements. A federal-level project is under preparation to support and strengthen local self government in the weak regions of the Northern Caucasus. It would also improve the quality of settlement-level social infrastructure.

- Investing in municipal development: On-going and possible future regional projects have significance for overall municipal development and the quality of municipal services. This includes the on-going Saint Petersburg Economic Development Project and the Housing and Communal Services project, which became effective in February 2010. Cultural Heritage II, slated for negotiations in June 2010, is aimed at developing cultural heritage tourism as a resource for socio-economic development in the participating regions. Possible regional and municipal subnational projects are under discussion on energy efficiency and water and heating system upgrades.

- $\quad$ Stepping up engagement on judicial reform: Assistance on judicial reform also involves the coordination of donor funds and special cooperation at the regional level. A judicial reform project complements the 2007-11 Federal Targeted Program for judicial modernization by improving the efficiency of dispute resolution and the transparency of judicial functioning. A complementary grant from the Government of Japan will provide support to Perm Krai and Leningradskaya Oblast on demand-side justice sector issues such as legal aid to the poor and juvenile justice. In addition, at the request of the Chairman of the Supreme Commercial Court the Bank plans to partner with it and the Ministry of Economic Development to support the drafting of framework legislation to strengthen administrative resolution of disputes and complaints handling, as well as individual bankruptcy law.

- $\quad$ Supporting anti-corruption initiatives: As a coherent national-level anti-corruption program may begin to take shape, the Bank may explore avenues of possible constructive contributions to such anti-corruption initiatives.

\section{(c) Improving the delivery of social and communal services}

3. The Government has prioritized the social sector and social services in its mediumterm program. Given that the primary responsibilities and initiatives for reform in these services will be at the sub-national level, the Bank will concentrate its focus on the regions. Main activities include the continuation of work in the areas of poverty, education, and health. Most recent additional activities include monitoring of labor market developments (at 
the federal and regional levels), and technical assistance for design and monitoring of active labor market programs. Monitoring of social trends and project design for improvement of quality of social services at the local level will be continued in the Southern Federal Okrug and in other regions under fee-based services arrangements. Another critical area for improving living standards is provision of housing and communal services. The government places high importance on improving the performance of the housing and communal services (HCS) sector and on the delivery of high quality services by communal enterprises, and closely links service provision with improving the quality of life.

- $\quad$ Continuation of the poverty work: In addition to continued cooperation with Rosstat and federal ministries, the emphasis of the Bank poverty work (in cooperation with DFID) has moved to the regional level. The Bank is working, and will continue to work, directly with regions on monitoring poverty and improving social assistance programs aimed at better targeting. Regional social protection strategies were elaborated for several regions. A program for modernization of Moscow city social protection is under preparation. Successful models of cooperation can be scaled up to similar regions.

- Improving the health of the population: The Bank will continue its engagement with the government on adult health, and the development of a national strategy to improve the health of the population, with the goal of reversing the strongly negative trends in premature mortality and morbidity and improving efficiency and quality of service delivery. The Bank is engaging federal and regional authorities on important agenda of health financing, health system organization and restructuring. Another priority is to ensure knowledge transfer on modalities of appropriate risk pooling, insurance, and sustainable health financing. The Bank is actively involved in advocacy for public health agenda, including alcohol and tobacco taxation and promotion of healthy life styles. Advice on road safety is supporting critical measures to reduce the rate of fatality and injury on the roads. As a follow up to earlier child welfare efforts and jointly with international donors the Bank will assist in design and implementation of practical mechanisms for family support, preventive social welfare and child care at federal and regional level. Additional advocacy, public awareness and information sharing efforts jointly with government leaders, public figures, private sector and NGOs will be undertaken in support of critically needed government policies in this area. The Bank and IFC financed the first subnational project in the health sector in 2009 in the Chuvash Republic. The development of public-private partnerships in the health sector could be supported jointly by TA from the Bank and direct financing by IFC, which will continue to explore opportunities to finance private sector solutions to health sector challenges.

- $\quad$ Modernization and improvement of the education system and vocational training: Having completed several operations in education at the federal level, the Bank continues to be actively involved in advising federal and regional authorities on 
education policies and efficiency in education sector. The main focus of this work includes early childhood development and all levels of professional education and training. The Bank is actively engaging federal authorities through demand driven knowledge services, and providing advice to regions on their early childhood development policies and vocational education development. In parallel, the Bank is supporting several leading national universities in Tatarstan and Moscow on design of their modernization strategies and expansion of international linkages in research. Regional TA and university work is focusing on improving the quality of local professional labor supply in order to meet the needs of economic diversification and increased productivity. In FY11, the Bank is delivering an innovative Financial Literacy and Financial Education project $(\$ 110 \mathrm{mln})$ that will strengthen the ability of the population to take responsible financial decisions and reduce financial risks for individual households.

- Improvement in the provision of housing and communal services: The Bank's support in the infrastructure sector will largely focus on improving quality of utility services and housing. The Bank has a large portfolio focused on improving heating, water, wastewater, and other municipal services in selected regions. At present, the main intervention of the Bank in this sphere is centered around the Housing and Communal Services project that aims to promote reforms and provide financing in HCS on grant basis allocated to regions competitively. The project is supported by a $\$ 200$ million loan that became effective in February 2010. In addition, the Bank and IFC financed two projects in the utility sector through its sub-national lending instrument (namely, wastewater treatment in Ufa and heating system modernization in Mytischi) and there are a number of similar projects in pipeline. IFC helped develop the mortgage market in Russia, providing advisory services and facilitating \$6.8 billion worth of mortgage loans from 2005-2008, and will continue to provide relevant products and services with high developmental impact, including sustainable housing finance and mortgage finance, with a focus on reaching underserved regions.

- $\quad$ Residential Energy Efficiency Finance and Sustainable Energy Finance through IFC's integrated advisory and investment platforms: IFC's Residential Energy Efficiency (REE) Program works with partner financial institutions to stimulate investment in the energy-efficient renovation of multi-family residential buildings. To date little investment in REE has occurred in Russia due to regulatory barriers, lack of experience on behalf of financial institutions, and lack of awareness regarding the economic benefits of such investment. IFC is cooperating actively with IBRD and EBRD to maximize the impact on market development. IFC's Sustainable Energy Efficiency Program makes credit lines available to banks for on-lending for energy efficiency projects, and provides technical assistance to banks and private companies in order to raise the lending volumes available for energy-saving projects. 


\section{(d) Enhancing Russia's global role}

4. The Bank has a strong commitment to support Russia's increasing global role, and assist the country in fulfilling its global commitments. The Bank will continue cooperation with the Russian government in support of its emergence as an international donor and active member of multilateral organizations. In addition, the Bank will assist in establishment of mechanisms and implementation of specific actions arising from Russia's global engagements, such as the Climate Change and Biodiversity Conventions, and pandemic diseases initiatives. Specific areas for Bank's engagement in Russia are:

- $\quad$ Assistance in the formulation of an ODA system for Russia as emerging donor: The Bank will continue to assist Russia as an emerging donor, and will cooperate on the establishment of a national ODA system through training/capacity events, information sharing, and advisory services. With support from the Russia as a Donor Initiative DFID TF, the Bank is helping to strengthen statistics of development aid, strategic communications and development aid training programs. An "externally funded staff development program" will build Russian Government capacity for aid policy development and aid management. After supporting an Emerging Donor Meeting hosted by Russia in April 2006, the Bank and OECD contributed to preparation and delivery of a February 2010 international conference in Moscow on "New Partners in International Development Finance" that was attended by thirty-two countries and twelve international organizations.

- $\quad$ Providing access to the Bank's instruments for channeling Russian developmental assistance: The Bank will remain engaged with Russia on international policy initiatives developed under Russia's G-8 presidency, including on Russia's priority themes for international assistance - quality of education, improved access to energy by vulnerable groups, and controlling the spread of infectious diseases. The Bank is assisting in preparation of Russian contributions to multilateral TFs such as the Global Emergency Food Facility, the Education-For-All/Fast Track Initiative, Rapid Social Response TF, South-South Experience Exchange TF. The Bank will strengthen cooperation with Russia on a program of joint Russia-Bank aid initiatives in support of economic and human development in Central Asia, including support for labor migrants, agriculture, water and energy. Russia increased its contributions markedly to IDA15.

- $\quad$ Fulfilling international obligations related to global goods: The Bank and IFC are committed to help Russia implement its Climate Doctrine, which was adopted in May 2009. It includes a commitment by President Medvedev to cut up to $25 \%$ of greenhouse gas emissions from the 1990 level by 2020, including through increasing energy efficiency. The Bank and IFC have both submitted applications to Sberbank as the Designated National Authority for implementation of the Kyoto Protocol mechanisms. The World Bank's Rosneft Gas Flaring Reduction Project (the largest 
Bank JI project in ECA) is expected to produce 6.8 million tons of Emission Reduction Units (ERU) for 3 years for an estimated US\$75 million purchase contract with Bank carbon funds, while the joint IFC and Core Carbon Group GHG reduction project under the Netherlands European Carbon Facility would produce 2 to 3 million ERUs. The Bank will continue participation and support for the Ministerial Conference on Forest Law Enforcement and Governance in Europe and North Asia.

- $\quad$ Linking Russian companies to global markets: IFC and MIGA activities are also relevant to the expansion of Russia's global role through facilitation of trade and investment linkages between Russian firms and global markets. In keeping with its global strategic objective to encourage investment across emerging markets (SouthSouth investment), IFC will continue to actively support strong, reputable Russian clients in investments elsewhere in emerging markets. Consistent with its strategic objective to support South-South investments through the provision of guarantees, MIGA will continue to proactively engage Russian companies planning to invest in emerging markets. 


\section{ANNEX III. RUSSIAN FEDERATION: STATISTICAL ISSUES}

\section{Assessment of Data Adequacy for Surveillance}

General: Data provision is broadly adequate for surveillance. However, in the context of emerging data demands for assessing external vulnerabilities, the scope for further data improvements exists.

Russia is an SDDS subscriber, has a range of statistical dissemination formats, and reports data for the Fund's statistical publications. These sources inform surveillance.

National Accounts: Data are broadly adequate for surveillance, but the reliability of recent quarterly GDP estimates (particularly for 2009 and the first quarter of 2010), and inconsistencies between published headline GDP growth rates, level series, and seasonally adjusted data are a concern expressed among a wide range of users, including Fund staff. This may point inter alia to lags in the revision schedule of the various data formats. The introduction of methodological changes in the compilation of important indicators, like the industrial production index, without releasing backward revisions of the series on a timely basis also impairs economic analysis. A historical revision of the industrial production index is due to be released in July 2010. Consistent with the new series, a historical revision of the annual and quarterly GDP series, which will also incorporate the results of the 2006 agriculture census as well as methodological improvements, is planned to be released during the third quarter of 2010 .

The Federal State Statistics Service (Rosstat) in general follows the 1993 SNA, although scope exists for methodological improvements in the calculations of volume measures of the production-based GDP estimates, including estimates of the output of financial intermediation services indirectly measured (FISIM). The imputed rental services of owneroccupied dwellings are undervalued. Improvements in the coverage of source data are constrained by an inadequate response to business surveys. The unavailability of balance sheet data continues to be an obstacle for analyzing balance sheet vulnerabilities.

Price statistics: Data are broadly adequate for surveillance, but time series analyses involving detailed CPI components are a challenge to perform because of limited time series data on CPI weights. Monthly CPI and PPI, both compiled using the Two-State (Modified) Laspeyres $(2000=100)$, cover all regions of the Russian Federation. In addition to the general CPI index, Rosstat also publishes indices for foodstuffs, non-food products, and services. Detailed CPI weight data have been made available on the Rosstat website beginning in 2006 and in the publication Prices in Russia beginning in 1995. Since 2009, detailed consumer expenditure data, used as the basis to develop the CPI weights, are posted on Rosstat's website annually. Earlier data on detailed household expenditures have been published in the following publications: Prices in Russia 2004 and Prices in Russia 2006. Detailed PPI weight data are not published, rendering time series analysis difficult; however, detailed data on total annual sales, which are used to develop weights for the PPI, are published by economic activity on the Rosstat website under the Entrepreneurship section, industrial subsection. Like the CPI, detailed PPI weights should be published and easily accessible by 
users. Further efforts to improve the treatment of seasonal items in the core inflation index and a new household budget survey - which has been under consideration for some timecould significantly strengthen data quality.

Government finance statistics: For surveillance purposes, the timeliness and level of detail of the data disseminated can be improved. Data on the economic classification of expenditures are available with a considerable lag, while the data on functional classification of expenditure and financing differ from international standards. Historical data on the maturity structure of domestic and external federal debt are not published, except the most recent observation available through SDDS. Monthly data on the size and composition of ruble guarantees are not available prior to 2010. Historical monthly data on foreign currency debt are not available prior to 2009. In addition, there is no integrated debt monitoring and reporting system. Reconciliation of different datasets of fiscal statistics (budget execution, cash flow statement, GFSM 2001 format, SDDS) is difficult. The website where fiscal statistics are disseminated can be made more user friendly by consolidating all statistical links in a dedicated data dissemination page, available both in Russian and in English, and supplementing the data with relevant definitions, description of compilation methodology, and relevant analytical materials.

Monetary statistics: Since July 2008, the Central Bank of Russia (CBR) provides to the IMF, in the MFSM-recommended format for the surveys, summarized data on (i) the Central Bank Survey, (ii) the Other Depository Corporations Survey, (iii) the Depository Corporations Survey, (iv) the Other Financial Corporation Survey, and (v) the Financial Corporations Survey. In the context of the current global turmoil, analysis of balance sheet effects has been hindered by a lack of comparable data on the currency and maturity breakdown of banking-sector assets and liabilities. Adoption of data reporting in full detail of the framework for Standardized Report Forms (SRFs), as recommended by an STA mission in 2007, would provide information on the currency and instrument breakdowns of the banking sector assets and liabilities. Starting in July 2010, the CBR plans to include in the Surveys the breakdown of positions by currency.

External sector statistics: While balance of payments data are broadly adequate for surveillance, and significant improvements have been made to enhance data quality, there remains scope for improving the coverage of certain components of the current, capital, and financial accounts. Improving the detail of supplemental data on the financial account would facilitate the analysis of relatively complex flows. For example, supplemental data on gross flows of long-term external debt (i.e., drawings and repayments) have been published for non-financial enterprises and government, but similar data for banks are not available, which have hampered staff efforts to analyze vulnerabilities resulting from external debt. The balance of payments is compiled according to the framework of the Fund's Balance of Payments Manual, fifth edition (BPM5) and the CBR is actively implementing the recommendations of the BPM6. Partial data from a variety of sources are supplemented by the use of estimates and adjustments to improve data coverage. In particular, the CBR makes adjustments to merchandise import data published by the Federal Customs Service to account for "shuttle trade," smuggling, and undervaluation. Statistical techniques are also used to estimate transactions and positions of foreign-owned enterprises with production sharing 
agreements, and these techniques are continuously being improved. At the same time, Russian compilers are seeking to reconcile their data with those of partner countries. Improvements have been made in the coverage and quality of surveys on direct investment, and the CBR is participating in the Fund's Coordinated Direct Investment Survey.

Headline data on reserves are reported to the Fund and the markets on a weekly basis with a four-business day lag. Comprehensive information is reported in the Reserves Template with a lag of 20 days, exceeding SDDS timeliness requirement of one month.

\section{Data Standards and Quality}

Subscriber to the Special Data Dissemination Standard (SDDS) since January 31, 2005. SDDS flexibility option used for the timeliness of data on central government operations. A data ROSC prepared in October 2003 was published on the IMF website on May 14, 2004. A data ROSC reassessment in June-July 2010 concluded that Russia's macroeconomic statistics are generally of high quality. It found that compiling agencies have made significant progress in adopting international statistical methodologies and best practices.

\section{Reporting to STA (Optional)}

Data are being reported for publication in the International Financial Statistics (IFS), Government Finance Statistics Yearbook, the Direction of Trade Statistics, and the Balance of Payments Statistics Yearbook. Monetary data reported as the basis for publication in IFS are in the format of summarized surveys rather than in the full detail of the SRFs that present positions by financial instrument disaggregated by currency (national and foreign) and the economic sector of counterparty. 


\section{RUSSIAN FEDERATION: TABLE OF COMMON INDICATORS REQUIRED FOR SURVEILLANCE}

(As of May 31, 2010)

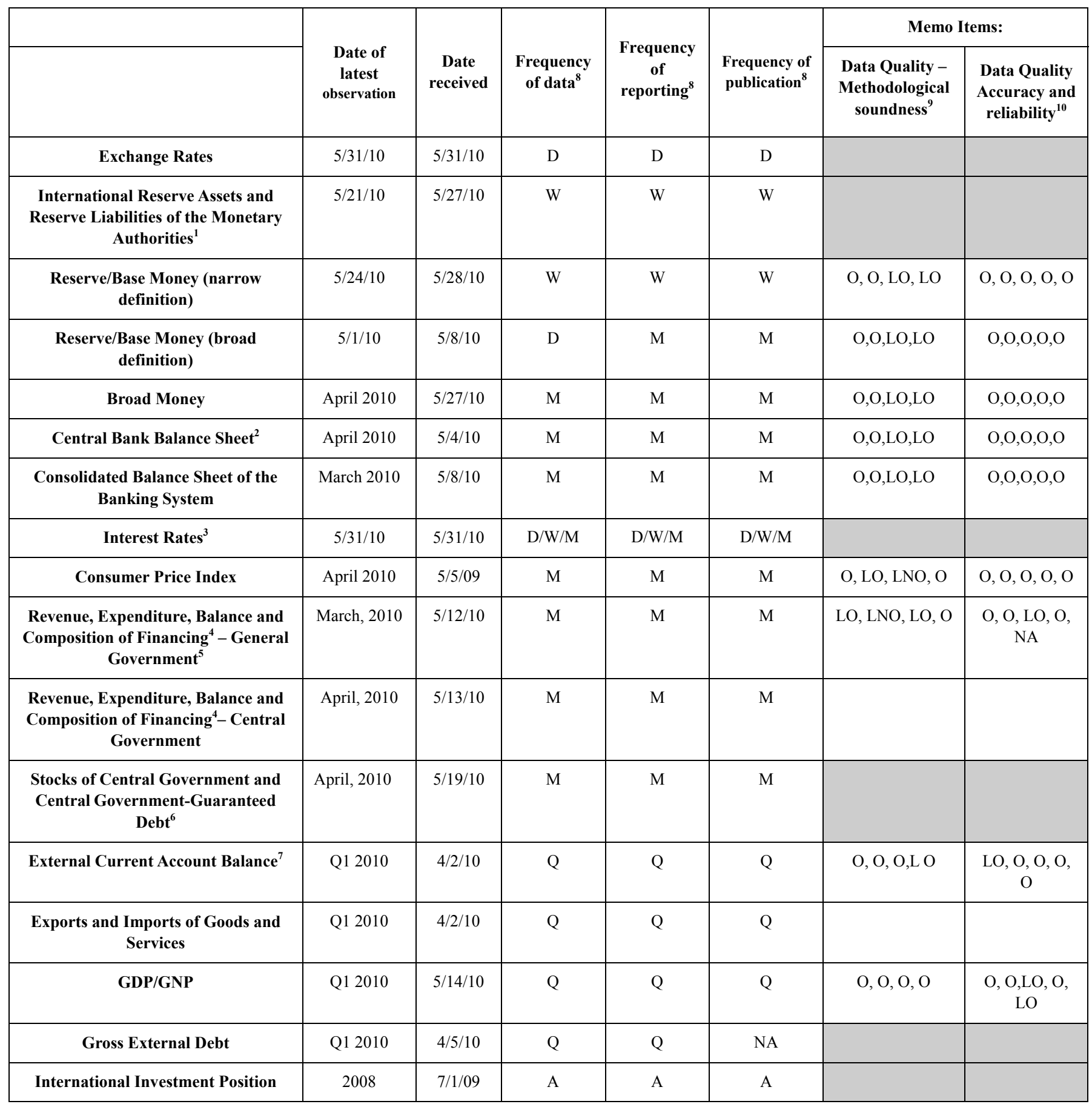


${ }^{1}$ Any reserve assets that are pledged or otherwise encumbered should be specified separately. Also, data should comprise short-term liabilities linked to a foreign currency but settled by other means as well as the notional values of financial derivatives to pay and to receive foreign currency, including those linked to a foreign currency but settled by other means.

${ }^{2}$ Ratings refer to Central Bank Survey.

${ }^{3}$ Both market-based and officially-determined, including discount rates, money market rates, rates on treasury bills, notes and bonds.

${ }^{4}$ Foreign, domestic bank, and domestic nonbank financing.

${ }^{5}$ The general government consists of the central government (budgetary funds, extra budgetary funds, and social security funds) and state and local governments.

${ }^{6}$ Including currency and maturity composition.

${ }^{7}$ Ratings refer to Balance of Payments.

${ }^{8}$ Daily (D); Weekly (W); Monthly (M); Quarterly (Q); Annually (A); Irregular (I); Not Available (NA).

${ }^{9}$ Based on the findings of the ROSC Data Module (Reassessment) mission in the field as of July 7, 2010 for the dataset corresponding to the variable in each row. The assessment is subject to review at IMF Headquarters. The assessment indicates whether international standards concerning (respectively) concepts and definitions, scope, classification/sectorization, and basis for recording are fully observed (O), largely observed (LO), largely not observed (LNO), or not observed (NO).

${ }^{10}$ Same as footnote 7, except referring to international standards concerning (respectively) source data, statistical techniques, assessment and validation of source data, assessment and validation of intermediate data and statistical outputs, and revision studies. 


\section{INTERNATIONAL MONETARY FUND}

EXTERNAL

Public Information Notice (PIN) No. 10/105

FOR IMMEDIATE RELEASE

August 2, 2010
International Monetary Fund

$70019^{\text {th }}$ Street, NW

Washington, D. C. 20431 USA

\section{IMF Executive Board Concludes 2010 Article IV Consultation with Russian Federation}

On July 23, 2010, the Executive Board of the International Monetary Fund (IMF) concluded the Article IV consultation with Russian Federation. ${ }^{1}$

\section{Background}

Following a deep recession, the Russian economy has improved, but the recovery remains fragile. In 2009, GDP fell by 7.9 percent, as domestic demand contracted sharply in the first half of the year, following plunging oil prices and an abrupt reversal of capital flows that brought a multi-year credit boom to an end. The economy began to recover in the second half of 2009 amid a pick-up in exports and inventory accumulation. After some temporary softness in the first quarter of 2010 , short-term indicators point to a strengthening of the recovery. While all components of demand now appear to be expanding, growth is becoming increasingly driven by consumption, reflecting to a large extent the recent 45 percent cumulative increase in pensions and other policy support. Inflation has come down rapidly in the context of a large output gap. Labor market conditions have improved, with the unemployment rate declining and real wages strengthening modestly. The overall balance of payments has remained in surplus, and the ruble has appreciated considerably since its trough in February 2009.

The banking system is still under strain and credit is likely to recover only gradually. Until recently, bank lending remained subdued, amid weak demand for credit and the continuing efforts by banks to restructure their balance sheets. There are signs, however, that the

\footnotetext{
${ }^{1}$ Under Article IV of the IMF's Articles of Agreement, the IMF holds bilateral discussions with members, usually every year. A staff team visits the country, collects economic and financial information, and discusses with officials the country's economic developments and policies. On return to headquarters, the staff prepares a report, which forms the basis for discussion by the Executive Board. At the conclusion of the discussion, the Managing Director, as Chairman of the Board, summarizes the views of Executive Directors, and this summary is transmitted to the country's authorities. An explanation of any qualifiers used in summings up can be found here: http://www.imf.org/external/np/sec/misc/qualifiers.htm.
} 
accumulation of overdue loans is now decelerating, and that banks are scaling back efforts to boost provisions and capital. In this context, credit growth picked up modestly in March and April, reflecting an improvement in credit demand and moderating credit supply constraints. The authorities have been exiting from extraordinary banking sector support extended during the crisis.

Significant fiscal stimulus was provided in 2009, and the relaxation is set to continue in 2010. The general government nonoil deficit increased from 81/4 percent of GDP in 2008 to 15 percent of GDP, almost entirely on account of higher spending. However, much of the expansion was targeted at low-multiplier areas, such as strategic sectors and defense and security. By end2009 , the underlying federal government nonoil balance was some 9 percent of GDP above both its pre-crisis level and the government's own medium-term target. In June, the government passed a supplementary budget, entailing a further slight increase in the federal nonoil deficit in 2010.

Monetary policy has been accommodative amid a more flexible exchange rate. Against the backdrop of a more stable external outlook and falling inflation, the Central Bank of Russia (CBR) cut its refinancing rate by 525 bps to 73/4 percent from its peak in April 2009. However, given the uncertain economic outlook and increased risk aversion that persisted in 2009, deposit and lending rates remained relatively high until recently. At the same time, the exchange rate has become more flexible. This has, however, occurred in the context of a weaker balance of payments and a sizeable output gap, which has reduced the tradeoff between inflation and exchange rate objectives.

Against this backdrop, the near-term economic outlook is for a moderate recovery. GDP growth is projected to reach $4 \frac{1}{4}$ percent in 2010 , reflecting a turn in the inventory cycle and a boost to

consumption from rising real wages and a gradual resumption of bank lending. However, absent sustained increases in oil prices, underlying growth momentum is expected to recover only slowly, causing annual growth to fall back to around 4 percent in 2011. Reflecting the output gap, still-weak demand, and continued ruble appreciation, inflation is projected to remain subdued, reaching 6 percent (y-o-y) at end-2010 and 51/2 percent at end-2011. The current account is expected to improve in 2010 before deteriorating modestly in 2011 as import growth picks up.

\section{Executive Board Assessment}

Executive Directors commended the authorities' forceful response to the recession, noting that the pre-crisis policy of taxing and saving much of the oil windfall in a stabilization fund had created significant space for fiscal expansion, monetary easing, and extraordinary liquidity support to the banking system, while also helping to prevent an abrupt ruble depreciation. Given the near-term prospect of a recovery with lower potential growth, Directors agreed that the main challenges will be to implement medium-term fiscal consolidation, mitigate pressures for real appreciation and inflation, restore the health of the banking system, and improve the investment climate through ambitious structural reforms. 
Most Directors considered that, given the scale of the required fiscal adjustment, the authorities should begin now to gradually withdraw the stimulus and step up the process in 2011-12.

Directors regretted the recently passed supplementary budget and cautioned against another supplement in the fall. They emphasized that-with most of the stimulus having taken the form of permanent measures, notably higher pensions-advancing long-stalled public sector reforms will be critical to preventing renewed overheating and rapid real appreciation. Directors encouraged the authorities to strengthen the fiscal framework. To ensure an effective countercyclical fiscal stance and anchor fiscal policy over the medium term, they advised the authorities to avoid the use of supplementary budgets and firmly focus annual and medium-term budgets on the nonoil deficit.

Most Directors stressed that monetary policy should focus on controlling inflation, and advised the authorities that the next move should begin a tightening cycle. A few other Directors cautioned that a tightening at this stage would be premature and could lead to a resurgence of capital inflows and greater exchange rate volatility. Directors noted the staff's assessment that the exchange rate is broadly in line with fundamentals. They welcomed the recent increase in exchange rate flexibility. Most Directors considered that greater exchange rate flexibility could help limit speculative capital flows and strengthen incentives for domestic borrowing. A few Directors, however, thought that the economy is not yet ready to cope with the increased exchange rate volatility that could accompany greater flexibility, in particular given the country's reliance on global commodity prices and the foreign exchange exposure of the financial sector.

Directors welcomed the progress achieved on banking supervision, and recommended that loan risk assessment be strengthened and provisioning made more forward-looking. They recommended that the CBR be given greater supervisory powers, particularly regarding consolidated supervision and connected lending, which remains a potential risk. Given the high level of reserves, the authorities remain well-positioned to safeguard financial stability. However, Directors stressed the importance of dealing decisively with the overhang of nonperforming and restructured loans, which could deter economic growth by hampering sustained credit expansion.

Directors emphasized that reinvigorating structural reforms remains a key priority, given the likely lower potential output growth going forward. They stressed the need to improve the investment climate for private sector activity and boost the potential for productivity gains. Directors welcomed the recent progress toward WTO accession. They underscored that such reforms, alongside the policy of taxing and saving oil revenues, remain key to the modernization and diversification of the Russian economy.

Public Information Notices (PINs) form part of the IMF's efforts to promote transparency of the IMF's views and analysis of economic developments and policies. With the consent of the country (or countries) concerned, PINs are issued after Executive Board discussions of Article IV consultations with member countries, of its surveillance of developments at the regional level, of post-program monitoring, and of ex post assessments of member countries with longer-term program engagements. PINs are also issued after Executive Board discussions of general policy matters, unless otherwise decided by the Executive Board in a particular case. The staff report (use the free Adobe Acrobat Reader to view this pdf file) for the 2010 Article IV Consultation with Russian Federation is also available. 
Russian Federation: Selected Macroeconomic Indicators, 2007-11

\begin{tabular}{|c|c|c|c|c|c|}
\hline & 2007 & 2008 & 2009 & 2010 & 2011 \\
\hline & & & & Proj. & Proj. \\
\hline & & \multicolumn{4}{|c|}{ (Annual percent change) } \\
\hline \multicolumn{6}{|l|}{ Production and prices } \\
\hline Real GDP & 8.1 & 5.6 & -7.9 & 4.3 & 4.1 \\
\hline \multicolumn{6}{|l|}{ Consumer prices } \\
\hline Period average & 9.0 & 14.1 & 11.7 & 6.2 & 5.7 \\
\hline End of period & 11.9 & 13.3 & 8.8 & 6.0 & 5.4 \\
\hline \multirow{2}{*}{ GDP deflator } & 14.4 & 18.0 & 2.3 & 8.9 & 6.6 \\
\hline & \multicolumn{5}{|c|}{ (Percent of GDP) } \\
\hline \multicolumn{6}{|l|}{ Public sector } \\
\hline \multicolumn{6}{|l|}{ General government } \\
\hline Overall balance & 6.8 & 4.3 & -6.2 & -5.6 & -3.1 \\
\hline Revenue & 39.8 & 38.6 & 34.4 & 34.1 & 35.0 \\
\hline Expenditures & 33.1 & 34.3 & 40.6 & 39.8 & 38.0 \\
\hline Primary balance & 7.3 & 4.8 & -5.6 & -4.9 & -2.2 \\
\hline Nonoil balance & -3.9 & -8.3 & -15.0 & -14.6 & -11.5 \\
\hline Nonoil balance excl. one-off receipts $1 /$ & -6.2 & -8.3 & -15.4 & -14.6 & -11.5 \\
\hline \multicolumn{6}{|l|}{ Federal government } \\
\hline Overall balance & 6.1 & 3.5 & -5.9 & -5.9 & -3.4 \\
\hline Nonoil balance & -3.0 & -7.6 & -13.7 & -13.9 & -10.9 \\
\hline \multirow[t]{2}{*}{ Nonoil balance excl. one-off receipts $1 /$} & -5.3 & -7.6 & -14.1 & -13.9 & -10.9 \\
\hline & & \multicolumn{4}{|c|}{ (Annual percent change) } \\
\hline \multicolumn{6}{|l|}{ Money } \\
\hline Base money & 33.1 & 2.9 & 7.4 & 19.1 & 17.1 \\
\hline Ruble broad money & 47.5 & 1.7 & 16.3 & 26.9 & 18.6 \\
\hline \multicolumn{6}{|l|}{ External sector } \\
\hline Export volumes & 4.4 & -2.6 & -7.9 & 8.3 & 4.9 \\
\hline Oil & 5.4 & -2.6 & 3.0 & 1.8 & 1.6 \\
\hline Gas & -5.4 & 1.8 & -13.8 & 12.0 & -0.9 \\
\hline Non-energy & 6.7 & -4.4 & -18.5 & 16.4 & 11.0 \\
\hline \multirow[t]{2}{*}{ Import volumes } & 25.1 & 11.1 & -30.0 & 17.4 & 14.2 \\
\hline & \multicolumn{5}{|c|}{ (Billions of U.S. dollars; unless otherwise indicated) } \\
\hline \multicolumn{6}{|l|}{ External sector } \\
\hline Total merchandise exports, fob & 354.4 & 471.6 & 303.4 & 380.6 & 408.9 \\
\hline Total merchandise imports, fob & -223.5 & -291.9 & -191.8 & -238.0 & -271.9 \\
\hline External current account & 77.0 & 103.7 & 49.0 & 66.9 & 60.5 \\
\hline External current account (in percent of GDP) & 5.9 & 6.2 & 4.0 & 4.5 & 3.6 \\
\hline \multicolumn{6}{|l|}{ Gross international reserves } \\
\hline Billions of U.S. dollars & 478.8 & 427.1 & 439.0 & 478.4 & 516.6 \\
\hline Months of imports $2 /$ & 20.3 & 14.0 & 20.8 & 18.3 & 17.4 \\
\hline Percent of short-term debt & 221 & 289 & 298 & 400 & 375 \\
\hline \multicolumn{6}{|l|}{ Memorandum items: } \\
\hline Nominal GDP (billions of U.S. dollars) & 1,305 & 1,671 & 1,240 & 1,488 & 1,690 \\
\hline Exchange rate (rubles per U.S. dollar, period average) & 25.6 & 24.9 & 31.7 & $\ldots$ & \\
\hline \multirow{2}{*}{$\begin{array}{l}\text { World oil price (U.S. dollars per barrel, WEO) } \\
\text { Real effective exchange rate (average percent } \\
\text { change) }\end{array}$} & 71.1 & 97.0 & 61.8 & 75.3 & 77.5 \\
\hline & 5.6 & 6.6 & -6.6 & $\ldots$ & \\
\hline
\end{tabular}

Sources: Russian authorities; and IMF staff estimates.

1/ Excludes one-off tax receipts from Yukos in 2007 and one-off transfers from Nanotechnology and Housing Funds in 2009.

2/ Months of imports of goods and non-factor services. 